\title{
The effect of board composition and managerial pay on Saudi firm performance
}

\author{
Mamdouh Abdulaziz Saleh Al-Faryan ${ }^{1,2,3,4,5,6,7}$ (D)
}

Accepted: 5 February 2021 / Published online: 2 May 2021

(c) The Author(s) 2021

\begin{abstract}
Using five empirical methodologies to account for endogeneity issues, this study investigates the effects of board independence and managerial pay on the performance of 169 Saudi listed firms between 2007 and the end of 2014. Studying board independence and managerial pay utilises the main internal governance mechanism in relation to firm performance; therefore, the effect of the 2009 exogenous regulatory shock on board independence was also examined to learn whether it impacted firm performance. The empirical results show that the board composition-performance relationship is endogenous. Strong evidence is found through the dynamic generalised method of moments estimation, which indicates that board composition has a positive relationship with return on assets, and poor past performance of listed firms has a negative impact on the current level of performance. The difference-in-differences approach results show a positive relationship between board composition, stock returns, and Tobin's $\mathrm{Q}$. The findings also reveal that managerial pay has a positive relationship with firm performance, although when endogeneity is considered, there is a smaller positive relationship and a decrease in significance levels. Thus, payfor-performance in Saudi Arabia matters, and firms are not simply controlled by the government. The results of this study have implications for both policy makers and investors. In particular, policy makers and Saudi regulators can evaluate the impact of Saudi corporate governance arrangements and, in so doing, highlight changes in corporate governance arrangements that need to be made to achieve their economic objectives, such as Vision 2030. This study also contributes to the literature by showing the importance of considering endogeneity in studies.
\end{abstract}

Keywords Board composition · Managerial pay $\cdot$ Firm performance $\cdot$ Endogeneity Corporate governance $\cdot$ Saudi Arabia

JEL Classification G30 · G34 · G38 · J33 · K22 · L25

Mamdouh Abdulaziz Saleh Al-Faryan

Al-Faryan@hotmail.com

Extended author information available on the last page of the article 


\section{Introduction}

In corporations, the board of directors' main responsibility is to protect and promote the interests of shareholders (i.e. owners). The responsibilities of the board also include endorsing and monitoring management initiatives, and evaluating, incentivising, and rewarding, as well as penalising, managerial performance. Corporate board members often include outside directors, as well as directors from inside the corporation and the firms' senior managers. Inside directors usually provide key updates on firm activities, while the contributions made by outside directors will draw on their individual experiences and expertise. The role of outside directors is to offer an alternative and objective approach to managerial decision making and, since their role is mandated by corporate law and corporate governance codes in countries with strong and well-established corporate governance systems, they are considered an important governance mechanism. Fama and Jensen (1983) argue that the reason for including outside directors on a board is to help mitigate the potential conflicts of interest between managers and shareholders, thereby mitigating agency costs. This is because corporations with outside directors on their boards are more likely to be well governed and thus generate better profits, as their managers are less likely to engage in activities that threaten the corporation's reputation. Studies have found that firms in countries with weak legal systems have lower values than those in countries with strong legal systems, but this value discount can be offset by improving firm-level governance quality. Examples of this literature stream include the studies of Klapper and Love (2004), Durnev and Kim (2005), Cheung et al. (2009), and Balasubramanian et al. (2010). An independent board is a vital governance mechanism that substitutes for the weak legal protection of minority shareholders and enhances value even in the presence of dominant shareholders, according to Dahya et al. (2008) and Claessens and Yurtoglu (2013).

The potential conflicts that may arise between shareholders and the board of directors as agents of the firm are the main focus of investigation in many studies, including the study described in this paper. Conflicts may arise when board members, especially internal directors whose careers may be tied to that of the CEO, have interests that are not closely aligned with those of the owners. For example, there are cases in which outside directors may favour the CEO's interests over those of the shareholders (although to a lesser extent than internal directors), especially when close family ties exist. In reality, the CEO is almost always the one who nominates and selects the board members. This led Mace (1971) to point out that even outside directors may fall into the trap of being more highly attuned to the CEO and management interests than to those of the firm's owners. Weisbach (1993), among others, refers to board composition as the ratio of outside to inside directors, noting that the governance structure hinges on several variables, including ownership of shares by board members, top management compensation, and board composition. He also argues that certain structures will systematically outperform others and that the underlying variables offer the best way to examine governance structures. Therefore, this study fills a gap in the literature by exploring the board structure and managerial pay of publicly listed Saudi firms and their impact on firm performance; this is an under-researched area mainly due to the lack of available data for Saudi Arabia. Therefore, it is imperative to examine several issues specific to the impact of board structure and performance, including the effect of the 2009 regulatory change regarding board independence of publicly listed Saudi firms.

The change in the Saudi corporate landscape, a direct result of the change in the regulations relating to Saudi board independence, also calls for an empirical examination. The 
dataset and variables used in this empirical study have not previously been made available, which explains why the abundance and scope of corporate governance research using Saudi data is limited. Earlier Saudi studies have generally lacked empirical rigour and meaningful discussion of Saudi board composition and firm performance. This study thus aims to compensate for this deficiency and thereby contribute to the literature not only by accounting for the endogenous nature of Saudi board structures, managerial pay, and firm performance but also addressing the following questions:

- Does the independence of Saudi boards result in a positive relationship with firm performance?

- Is the 2009 exogenous shock as a result of the regulatory changes applied to Saudi boards likely to positively impact firm performance?

- Does lagging prior performance (a proxy for endogenous factors): (a) influence current firm performance and (b) the board composition-performance relationship?

- Is the increasing monitoring cost of Saudi corporations likely to have a negative impact on firm performance?

- Does managerial pay have a positive impact on the performance of Saudi corporations?

- Do government firms display similar findings to all listed firms with board independence and managerial pay?

The empirical analysis in this paper makes the following three main contributions to the corporate governance literature. To the best of my knowledge, this is the first study to use Saudi data to examine the impact of board composition and managerial pay on firm performance for 169 Saudi listed firms between 2007 and the end of 2014. Further, it contributes to the literature by examining not only the effectiveness of independent directors and how they influence firm performance in Saudi Arabia, but also the effectiveness of these directors when they are faced with information asymmetry or high monitoring costs. In this respect, I make use of a dynamic panel data regression, which is often used in such corporate governance studies to describe the conditions under which inferences may advance beyond generalised least squares (GLS) or traditional fixed effects (FE) models. Moreover, the empirical methodology used in this study will help shed light on board composition performance and the managerial pay-performance relationship, while also considering endogeneity. Finally, this paper also sheds light on government firms, and whether board independence and managerial pay-for-performance matter.

The paper is organised as follows. The next section reviews the related literature on board composition, monitoring costs, and managerial pay. Section 3 describes the data, and Sect. 4 discusses the empirical methodology. Section 5 analyses, evaluates, and discusses the main empirical findings. Section 6 concludes the paper.

\section{Literature review and research hypotheses}

A corporation's board of directors is a set of agents or individuals within the corporation who are appointed as the firm owners' representatives in the oversight of the corporation's strategies, investment decisions, dividend payments, and corporate governance arrangements, as well as to ensure the accuracy of its financial information. Board composition refers to the ratio of the number of outside (independent) directors versus inside directors on the firm's board. In the literature, independent boards are generally considered an 
important governance mechanism. In their review of corporate governance literature on US and non-US corporations, Denis and McConnell (2003) and Claessens and Yurtoglu (2013) find theoretical and empirical evidence suggesting stronger boards enhance firm performance through better monitoring of management and fewer agency issues. Yeh and Woidtke (2005), Black et al. (2006), Choi et al. (2007), Dahya and McConnell (2007), and Black and Kim (2012) further note that independent boards can serve as a substitute for weak legal or regulatory environments and act as a form of protection for the rights of minority shareholders.

Questions have also been raised about whether outside directors contribute to the discipline of managers as a result of the labour market and other internal governance mechanisms, such as auditing and ownership structure. It has been argued that outside directors may have been selected by insiders, who provide the firm with information they themselves have analysed (Mace 1986; Patton and Baker 1987). However, it is well known that outside directors are chosen by the board and have a legal obligation to act independently in representing shareholders' interests. When outside directors fail to adequately perform their roles, they are subject to penalties. To ensure that such misconduct does not arise, directors are incentivised to perform their roles to maintain their reputation as competent monitors (Fama 1980; Fama and Jensen 1983; Ricardo-Campbell 1983). However, to remain attractive to other firms that wish to avoid scrutiny, directors may want to maintain their reputation and be seen as not destabilising the status quo through their objectivity and good conduct.

There is evidence to support the idea that external directors act independently from firm executives. For example, Mace (1971) discovers that excessively poor performance or weak proposals are more likely to be challenged by outside directors, while Weisbach (1988) notes that boards dominated by outside directors are more likely to dismiss the CEO for poor performance. Brickley and James (1987) point out that management remuneration is reduced in the presence of outside directors, and Brickley et al. (1994) argue that outside directors act in shareholder interests in their decision to adopt a poison pill. Further, Rosenstein and Wyatt (1990) report positive stock reactions when additional outside board directors were announced. Puni and Anlesinya (2020) find that the presence of both insiders and outsiders improved firm performance.

Therefore, the overall impact of board composition and structure on firm performance is debatable. In their review of US literature, Hermalin and Weisbach (2003) conclude that board composition has no effect on firm performance. By contrast, non-US studies provide evidence that a positive relationship exists between board composition and firm performance; for instance, Choi et al. (2007), Black and Khanna (2007), and Black and Kim (2012) demonstrate a positive relationship between board independence and firm performance. Dahya et al. (2008) confirm a positive relationship between board independence and firm performance for 22 non-US countries and note the presence of a stronger relationship in countries with lower levels of investor protection. Yeh and Woidtke (2005), Aggarwal et al. (2009), and Bruno and Claessens (2010) examine markets with legal and regulatory frameworks less developed than those in the US and report similar results. The difference between US and non-US firms has been attributed to a substitution effect between internal and external governance mechanisms, which suggests that internal mechanisms, such as improvements in monitoring primarily due to the involvement of outside directors on boards, become more critical in non-US countries where legal institutions and regulatory frameworks are weaker and furnish lower levels of investor protection, as Ferreira and Matos (2008) and McCahery et al. (2016) note. Moreover, markets with weak 
mechanisms for overseeing corporations, market competition, the financial press, cultures, and norms can also affect this relationship.

In their study of US independent directors for 1991-2003, Cicero et al. (2013) report that independent directors dominate US boards, accounting for $63-71 \%$ of a firm's board. They suggest that the unavailability of data on boards with other compositions might be why US studies have failed to shed light on the board independence-firm performance relationship. Linck et al. (2008) and Wintoki et al. (2012) note there is a shortage of strong evidence on boards being endogenously determined based on firms' operating environments.

Further, Hermalin and Weisbach (2003), Dahya and McConnell (2007), and Adams et al. (2010) point out that model rigour may suffer as a result of potential unobserved heterogeneity, simultaneity bias, and reverse causality. Unobserved heterogeneity arises when unknown factors affect both the dependent and independent variables. For example, as Hermalin and Weisbach (1998) note, high managerial ability is generally unobservable but affects firm performance positively, as firms with highly competent managers are less likely to require strong monitoring or independent boards. The issue of simultaneity arises when the independent variables are a function of the expected values of the dependent variable. For example, management share ownership is likely to be jointly endogenous and related to firm performance. Further, since managers invariably possess better quality information, they can better anticipate future firm performance. As a result, such managers may elect to increase their shareholdings when they have positive knowledge and reduce them when the outlook is negative. According to Hermalin and Weisbach (1991), such trends would suggest a positive relationship between firm performance and shareholding, which has nothing to do with actual performance. Reverse causation was also identified by Hermalin and Weisbach (1988), who note that poor firm performance results in inside directors being replaced with outside directors. Therefore, firms that underperform over a given period are likely to have a higher than average number of outside directors. If these firms are included in the regression analysis, the results would likely erroneously indicate that the poor performance was caused by outside directors.

Hermalin and Weisbach (2003) also point out that the results of past studies that support a positive relationship between board composition and firm performance are possibly due to inadequate control of endogenous associations. For example, Baysinger and Butler (1985) suggest board composition effects, although they did not control for composition determinants such as ownership, while Weisbach (1988) and Hermalin and Weisbach (1988) report that ownership has an inverse association with the proportion of outside directors. Therefore, Baysinger and Butler's (1985) findings may be interpreted as being distorted by ownership effects as opposed to board composition effects, or they could be erroneous as a result of uncontrolled factors.

Hermalin and Weisbach (1998) argue that board structure depends on trade-offs between the board and the CEO's bargaining power. The CEO's bargaining power is a function of perceived ability as measured by past performance; as such, poor firm performance is considered to negatively affect the board's assessment of the CEO's ability, discounting that individual's bargaining power. However, it ultimately leads to including more independent directors on the board. The view that board structure is determined by past performance is shared by Bhagat and Black (2002) and Hermalin and Weisbach (1988).

Raheja (2005) and Harris and Raviv (2008) maintain that past performance affects the firm's information environment, its profit potential, and the opportunity costs of outside directors. These factors, in turn, impact current board structure. Furthermore, if board structure is determined by firm characteristics and these characteristics are in turn related to past performance, then board structure is also related to past performance. Fama and 
Jensen (1983) and Boone et al. (2007) suggest that large-sized firms are more hierarchical and complex and, therefore, require larger boards to monitor and ratify the high volume of decisions made by senior managers. Boone et al. (2007), Coles et al. (2008), Linck et al. (2008), and Lehn et al. (2009) identify a positive relationship between board and firm size. That is, if size has a positive relationship with performance, then board size is also likely to have a positive relationship with past performance through the effects of performance on size. Further, Shan and McIver (2011) study Chinese firms' corporate governance characteristics between 2001 and 2005 and find that, for large firms only, board independence had a significant and positive impact on performance.

Wintoki et al. (2012) demonstrate that firm characteristics such as size and the market-to-book ratio are related to past firm performance. Their study supports Boone et al. (2007) and Linck et al. (2008) and further argues that the effect of past board structures on a firm's current characteristics is not as important as the effect of past board structures on current firm performance. Wintoki et al. (2012) also tackle the issue of endogeneity in the relationship between board structure and firm performance using the dynamic panel GMM estimator. They find no causal relationship between board independence and firm performance but propose that a dynamic relationship exists between the current values of explanatory variables and past values and performance. Past studies have overlooked this dynamic relationship and, therefore, suffered from serious endogeneity problems. This led to mixed findings, with inconsistent estimates and biased results in the opposite direction of the dynamic relationship. The findings were at least partially due to the negative bias arising from ordinary least squares (OLS) regressions or the positive bias arising from traditional fixed-effects regressions of board independence on performance, which ignored the dynamic relationship. The reliability of studies in this area is thus questionable, and the potential unreliability stems from endogeneity, overlooked or unobservable heterogeneity and simultaneity, the inability to identify exogenous factors, and the dearth of valid instruments or natural experiments to properly study the relationship. All these factors have substantial implications for the reliability of the data inferences.

Some studies focus on exogenous shocks. For instance, Black and Khanna (2007), Dahya and McConnell (2007), and Black and Kim (2012) study the effect of country-specific exogenous shocks on board independence and show that an increase in board independence leads to increased firm performance in India, the UK, and Korea, respectively. Li et al. (2015) focus on the effect of the exogenous shock of the Chinese share restructure reform in 2005 on the relationship between board independence and firm performance. The study checks for structural changes pre- and post-reform and reveals a positive relationship between the proportion of independent board directors and firm performance. The relationship is stronger in privately-owned firms than in state-owned firms, and there was no significant evidence to suggest board independence affects firm performance in state-owned firms. Their robustness test considers possible endogeneity by employing the lagged values of board independence ratios and using the average value of the board independence ratio as an instrumental variable. Moursli (2020) studied the exogenous change in Swedish board independence rules, which now require a majority independent board in large firms. The study found a negative market reaction to the change and attributed this to the increased busyness of independent directors.

Liu et al. (2015) study board independence and performance in China between 1999 and 2012, exploring how independent directors channel and exert their influence. They apply various methodologies to account for endogeneity and confirm that board independence has a positive impact on performance. The positive impact is stronger in state-owned firms 
than in privately-owned firms, in contrast to $\mathrm{Li}$ et al. (2015). Furthermore, independent directors restrict insider self-dealing and tunnelling and improve firm efficiency.

Wang (2014) reviews 30 papers on Chinese board composition and firm performance, finding that $63 \%$ report a positive relationship, $30 \%$ identify a negative relationship, and $7 \%$ find no significant relationship. The differences were attributed to numerous endogeneity issues, such as the fast-changing and evolving nature of corporate governance in China since the early 2000s. However, it was challenging to delineate the impact of board independence from other corporate governance reforms, thus making comparisons with other sample periods difficult (Chow 2007). Wang (2014) argues that cross-sectional differences in board composition and management compensation and whether the firm has a family-, private-, or government-owned structure can also affect the results. Wang (2014) posits that a more in-depth and focussed analysis would be required to fully investigate the board independence-firm performance relationship. Rashid's (2020) study of listed Bangladeshi firms has shown that board independence has a partial mediating relationship between ownership structure and firm performance.

Al Farooque et al. (2019) study 432 Thai listed firms post Asian crisis between 2000 and 2011 and argue that type II agency conflicts between large shareholders and minority shareholders are more likely to be the dominant conflict of interest in Thai firms than the type I conflict between shareholders and management. The study aims to investigate the tridirectional (e.g. simultaneous, causal, and endogenous) reciprocal/dynamic relationships between executive compensation, firm performance, and corporate governance using a dynamic GMM model. The study finds a positive reciprocal relationship between executive compensation and performance and between corporate governance and firm performance, but only a one-directional positive relationship between corporate governance and executive compensation.

Although Al Farooque et al. (2019) is an interesting paper, there are a few criticisms and improvements that can be made. First, the variables used in the models to study the relationship with Type II agency issues are exactly the same as those used in many studies that predominantly examine the Type I agency issue. It is unclear how these variables can address the Type II agency issue between large and small shareholders, although the results can easily represent the Type I agency issues studied in most of the literature. Also, the theoretical justifications were predominantly based on existing literature that focusses on the Type I agency issue. Second, like many other studies, this one excludes financial firms. Third, the study deliberately excluded data during the time of the Asian financial crisis. Thus, there is no way to tell whether the relationships are the result of any of the corporate governance changes made after the crisis or if they were even possibly relationships that already existed. Thus, the study does not fully account for endogeneity issues or tackle causality but only finds a relationship between three variables. The study could have been improved by using a full sample to capture everything from start to end; this is the best way to capture endogenous relationships, especially when using lags; otherwise, the results and their interpretation would be biased as a result of only looking at a snapshot. It would be more informative to include the Asian crisis data or even create a study of exogenous shocks as a result of the changes in corporate governance following the Asian crisis. The study could also have utilised another type of analysis, such as DID, to better capture a causality relationship.

More specifically, in their GMM model Eq. (1), they use top executives compensation as the dependent variable, and only one lag for the instrumental variables (i.e. total executive compensation, ROA, ROE, return on stock, Tobin's Q, board independence, board size, managerial ownership). The study also used all four current performance measures as 
independent variables. The first issue is that only one lag was used; this is insufficient, as it is highly likely to be related to the previous year and might not capture all the information. Most studies recommend two-year lags to adequately account for endogeneity. In Eq. (2), the dependent variables use the following year's performance variable, while corporate governance variables use a $t-1$ lag. Moreover, the performance variables (ROA, ROE, return on stock, and Tobin's Q) and governance variables are all included as independent variables using the current values at $\mathrm{t}=0$. Equations 3, 4, and 5 all follow a model similar to Eq. (2), using the following year's $(t+1)$ value as the dependent variable and including $\mathrm{t}=0$ for all variables and $\mathrm{t}-1$ for all lag variables. The main issue in all the above is how the model is constructed.

With a dependent variable such as board independence at $t+1$ and the independent variable board independence at $\mathrm{t}=0$, it is highly likely that the independent variable is related to the dependent variable, that is, related to the next year. Some variables do not change often; for example, board independence from this year to the next is likely to be similar. Furthermore, including lagged variables such as ROA at $\mathrm{t}-1$ and the same current variables $(\mathrm{ROA}$ at $\mathrm{t}=0)$ as independent variables makes it highly likely that they will be related to each other. More importantly, in the results, for every lagged variable that is significant, its corresponding current non-lag variable is also significant. This does not clarify the tridirectional focus the study wanted to take, as the endogenous impacts are not distinguished or highlighted as different from others. This might be the reason all the Hansen and autocorrelation tests supported the model and instrument. It can be argued that the study only highlights the interaction and not the tri-directional relationship.

Al Farooque et al. (2019) criticise FE analysis; however, the study could be improved by conducting FE or random effects (RE) tests as a tool for comparison, as well as to control fixed unobserved heterogeneity and make the results more robust. In this study, the authors were unable to compare the tri-directional relationships with any others as this was not tested. In unpublished studies, the authors conduct three-stage least squares regression; however, it is unclear which instruments they employed, the key factor, or the exact methods and models used.

Mishra (2020) investigates board independence in listed Indian firms between 2003 and 2019 and finds a negative relationship with performance. The study utilised only fixed effect and OLS regression models and attributed the results to the specific nature of the Indian market, finding that endogeneity issues may still be present in terms of poor performing firms taking corrective measures to increase independent directors.

Wei et al. (2018) conduct a literature review of 65 articles published in leading journals that study independent directors in Asian firms from 2001 to 2016. While the paper was only an organised review, it did suggest future research areas to extend studies of independent directors. Even though the review's main focus was study of the post Asian financial crisis in Asian economies, it also included articles from India, Bangladesh, and Turkey; however, it lacked literature from MENA countries. This might be due to their geographic location or that such literature was not available in leading journals.

\subsection{Monitoring costs}

Outside directors face additional costs compared to inside directors, and these costs affect their ability to effectively monitor and advise management. There are two main disadvantages to this approach. The first is information asymmetry, where insiders have superior information relative to outside directors regarding all aspects of the firm. Second, expertise 
disadvantages can also exacerbate this problem, since inside directors possess increased firm-specific expertise, whereas outside directors are likely to have more generic knowledge. Therefore, outside directors face additional costs in attaining firm-specific information and the expertise to effectively perform their duties. Maug (1997) finds that, in environments with higher information asymmetry, increasing the number of independent directors does not have many beneficial effects. Raheja (2005) and Adams and Ferreira (2007) postulate that the number of outside directors decreases as monitoring costs increase. Linck et al. (2008) and Duchin et al. (2010) find that the advantages of having more independent directors are reduced when information acquisition costs are higher. In other words, independent directors are more valuable when information acquisition costs are lower. Liu et al. (2015) demonstrate that the positive impact of board composition on performance is stronger in Chinese firms, where independent directors face lower costs to acquire firm-specific information.

\subsection{Managerial pay}

A key function of the board is to determine the top executive compensation structure (Fama and Jensen 1983). Today, listed firms are also required to have a separate executive compensation and remuneration committee. Therefore, there are various factors that influence executive compensation. Mehran (1995) argues that executive management compensation, share ownership structure, and board composition are mutually determined and also influenced by the firm's specific business nature; as such, firm performance and value are endogenously related.

\subsubsection{Director incentives}

Murphy (1985) criticised past studies that focus only on the visible aspects of remuneration, such as salary and bonuses, but ignore variables that are more sensitive to the firm's performance, such as stock options and awards. Furthermore, Murphy (1985) argues it is reasonable to assume stock prices affect management compensation, but this is not the only determinant of management remuneration. Mehran (1995) investigates the relationship between executive compensation structure and firm performance and finds support for incentive compensation, arguing that the type rather than the level of compensation motivates managers to improve firm performance. Mehran (1995) discovers that firm performance is positively related to the percentage of equity-based compensation. Furthermore, equity-based compensation is more common for firms with a greater proportion of outside directors. Jensen and Meckling (1976) and Grossman and Hart (1983) argue that agency costs are reduced when management and shareholder interests are aligned by ensuring that inside and outside managers both own shares in the firm, which then induces management to improve firm performance. Hermalin and Weisbach (1998) also note that incentivebased contracts increase director efforts and should ultimately lead to greater firm value. Jensen and Murphy (1990a) maintain that equity-based incentive contracts such as stock options are better than cash for tying management remuneration to performance. However, Harris and Raviv (1979) argue that managers prefer compensation to be structured in a way that minimises their personal risk. They prefer fixed cash compensation over stock, since stock values are, to some extent, outside management's control. Hirshleifer and Suh (1992) state that incentive contracts could lead to greater levels of risk-taking and other activities that could reduce firm value. Therefore, it might be preferable to hold compensation levels 
constant and structure managerial pay to be at least in part equity based (Paul 1992; Sloan 1993).

Adithipyangkul and Leung (2018) study the relationship between non-executive director incentives and firm performance and find that firm performance is better without any incentives or when more of such incentives are high-powered. The study also finds that the interaction between incentive pay in the presence of monitoring by large shareholders has a negative impact on performance and the monitoring presence of debtholders has a positive impact on firm performance. While corporate performance is a function of non-executive director incentive pay, it is not the only factor that influences performance; the relationship can be impacted by other endogeneity issues apart from those the authors mention. However, the study does use the $t+1$ and $t+2$ performance values as the dependent variables to account for reverse causality. To address omitted variable bias, the study includes control variables found in other studies. This does not fully tackle the endogeneity issues that might impact the results, such as unobserved heterogeneity; when unknown factors affect both the dependent and independent variables, control variables are unlikely to cover all omitted variables. While it can be impossible to develop the perfect model to describe a relationship, the study could be improved if it were to use additional empirical techniques to increase the robustness of its results. Simultaneity issues can also result in biased results when independent variables are a function of the expected values of the dependent variable. Although the authors regress current variables on future firm performance variables, there may be another variable that could be time variant or invariant that might impact the relationship.

\subsubsection{Ownership of shares}

Jensen and Meckling (1976) are pioneers in defining the relationship between management share ownership and firm value. They maintain that inside shareholders who manage the firm are able to extract rents from firm cash flows in the form of non-marketable perquisites and become entrenched. Therefore, insiders have incentives to pursue policies and investments that are profitable to them at the expense of the firm's shareholders. However, insider ownership can also improve firm performance due to reduced agency issues. Therefore, firm value depends on the proportion of shares held by insiders. Rashid (2020) supports this view even for developing markets such as Bangladesh; the researchers find that director ownership has a positive impact on firm performance and value. Morck et al. (1988) suggest that managers react to two opposing forces, depending on the extent of management ownership, which in turn impacts firm value. The first force is the natural tendency of managers to allocate firm resources to suit their own interests, which most likely conflicts with shareholder interests. This tendency has a negative impact on firm value. The second force has to do with the probability that as the managers' ownership level increases, their interests become more closely aligned with those of firm shareholders, positively impacting firm value. This relationship is an empirical one; there is no certainty about how a certain ownership structure will trigger each of these forces. Morck et al. (1988) also find a non-linear relationship between firm value and managerial ownership that initially increases for firms with managerial ownership ranging from 0 to $5 \%$. The relationship weakens as managerial ownership increases to $25 \%$ and rises again for managerial ownership levels above 25\%. Similarly, Hermalin and Weisbach (1991) find a non-monotonic relationship between Tobin's $\mathrm{Q}$ and the proportion of shares owned by all past and present CEOs. Their results differ from those of Morck et al. (1988) in terms 
of the ownership percentages at which certain forces become predominant. Their findings show that the relationship between CEO ownership and value is positive for the $0-1 \%$ CEO ownership level, negative between 1 and 5\%, positive between 5 and $20 \%$, and finally negative again above $20 \%$.

McConnell and Servaes (1990) investigate the cross-sectional relationship between firm value and equity ownership structures in two periods, 1976 and 1986. Both periods display non-linear relationships between firm value and the percentage of stock held by insiders. At ownership levels of 40-50\%, the firm value slope curves upward, while levels above $50 \%$ show a slight downward slope. Their results are robust due to the inclusion of multiple control variables, allowing them to avoid errors stemming from omitted variables. Further, they use ROA for robustness to ensure the results are not influenced by the method used to measure performance. Stulz (1988) and Hermalin and Weisbach (1991) also identify a curvilinear relationship between insider ownership and firm value. They suggest an optimal governance structure could exist, and this optimal structure is dependent on the specific issues a firm faces, since different firms face different issues. The empirical findings are consistent with the theory that corporate value is a function of the equity ownership structure and that managerial ownership can reduce agency costs and is thus likely to improve firm value. However, agency issues do not monotonically decrease with management's ownership of shares because, at larger levels of managerial ownership, managers can become entrenched. High levels of managerial ownership are common for family-controlled firms, which most likely put the family's interests ahead of those of other shareholders.

\subsubsection{CEO and top executive pay}

Murphy (1985) argues that the economic theory of management compensation points towards a positive relationship between managerial pay and firm performance, but there is limited empirical evidence that supports this relationship. Murphy (1985) proposes that past cross-sectional studies suffer from the omission of important variables such as managerial responsibility, entrepreneurial ability, firm size, and historic performance, causing seriously biased results. Therefore, Murphy's (1985) focus is not on the value of past assets that can fluctuate predictably and systematically with the firm's stock price but is instead on the more indirect and subtle relationship between current year compensation and firm performance. As a result, possible direct or mechanical links between managerial pay and firm stock price were eliminated or at least controlled. Murphy (1985) also finds a strong positive relationship between executive remuneration and firm performance measured by the shareholders' rate of return and sales growth, and these results are robust to stock market performance. Jensen and Murphy (1990b) explore the relationship between performance and pay, measured by the changes in executive wealth and firm performance. They express surprise at finding the lack of a strong relationship between the change in executive wealth and firm value. Olaniyi and Olayeni (2020) explore the causal relationship between CEO pay and firm performance in Nigeria and find a bi-directional relationship. They find that CEO pay causes firm performance and that firm performance negatively causes CEO pay. Moreover, they suggest that CEOs are rewarded for good performance but not punished for poor performance; thus, CEOs are highly rewarded even when their firms underperform. Bin et al. (2020) study the determinants of CEO pay in Chinese listed firms between 2009 and 2015 and find a positive association with firm performance. Conyon and He (2011) investigate the relationship between executive pay and firm performance in Chinese listed 
firms between 2001 and 2005. They find the relationship is stronger in non-state-controlled firms. Gu et al. (2010) find that firms under weak government control have higher pay levels and greater pay-performance sensitivity, whereas firms under greater government control have lower pay levels and lower pay-performance sensitivity. The study finds that pay incentive schemes act as a substitute governance mechanism when direct government control is reduced. This finding supports He et al.'s (2016) finding that government control can be weakened in firms with good corporate governance mechanisms, which serve as a substitute for government monitoring. Jiang et al. (2020) study how government ownership impacts management pay and how such pay impacts firm performance. The study finds that management pay is lower in state-owned enterprises (SOE) than in non-SOE, which induces poor performance in SOE. In contrast, Bin et al. (2020) do not find that CEO pay is affected by state ownership.

\subsubsection{Saudi literature}

There is not a long history of literature on corporate governance utilising Saudi data and extant studies focus on issues related to ownership structure and firm performance. For example, Al-Matari et al. (2012) study the impact of the legal system, regulations, and monitoring policies in Saudi Arabia. The corporate governance mechanisms they consider include board composition, CEO duality, board size, audit committee independence, audit committee activities, and audit committee size. Al-Matari et al. (2012) also look at internal corporate governance mechanisms, particularly the impact of the board of directors and audit committee on performance. They do not support the view that the board and committee mitigate agency costs, but find audit committee size is significant, although in the opposite direction of the stated hypothesis. The proportion of non-executive directors shows a significantly negative relationship with performance, but again in the opposite direction of what was expected. CEO duality, board size, audit committee independence, and audit committee meetings have the expected sign, but are not significantly related to firm performance. Similarly, Ghabayen (2012) studies 102 non-financial listed Saudi firms using their 2011 annual reports and investigates the relationships between board mechanisms such as those between audit committee size, audit committee composition, board size, and board composition and firm ROA. Ghabayen (2012) shows that audit committee size, audit committee composition, and board size have no effect on firm performance, but board composition shows a significantly negative relationship with firm performance, which lends support to Al-Matari et al.'s (2012) findings. A major problem with this study is that it only used one year of data and used ROA as the only performance measure.

Conversely, Habbash and Bajaher (2015) study board structure, with board composition, board size, and duality as governance mechanisms, and their impact on Saudi firm ROA. Habbash and Bajaher (2015) use a pooled sample of 338 firm-year datapoints of large, listed firms from December 2006 to December 2009. Using a panel data FE OLS regression method, Habbash and Bajaher (2015) find that board independence has a positive effect on firm performance, which contradicts the findings of Al-Matari et al. (2012) and Ghabayen (2012). Duality has a negative relationship with ROA, while board size has no significant relationship with ROA. It is worth noting that Habbash and Bajaher (2015) exclude firms in the banking and insurance sectors.

Altuwaijri and Kalyanaraman (2016) apply an FE method to study the relationship between board independence and firm performance for Saudi non-financial listed firms using a panel data sample consisting of 365 firms from 2010 to 2014 and operating profit 
and net profit as the performance measures. They show that board independence has a positive relationship with performance, although the dummy variable of excess board independence (over the regulatory minimum) was found to have no significant relationship with firm performance. However, the $\mathrm{R}^{2}$ in their models were over $70 \%$, which implies multicollinearity issues.

In his study of 329 Saudi firms over 2013-2015, Alshetwi (2017) excluded listed banks and insurance firms from the sample due to their specific regulatory requirements. He examined the relationships between board size, board independence, and firm performance using ROA. Alshetwi (2017) finds neither board size nor board independence is related to firm performance, but additional testing reveals that nonexecutive directors lack real independence and are ineffective and costly for the analysed firms. Alshetwi (2017) notes the dominance of a tribal culture, which he argues pays more attention to personal relationships over competency. The empirical models he uses follow Guest (2009) and Larmou and Vafeas (2010) and allow him to capture the impact of factors not included in their models. It is argued that the FE model used reduces the endogeneity issues in the board-performance relationship. Although the model considers endogeneity arising from time-invariant unobserved heterogeneity, it does not consider that from time varying heterogeneity, which is more likely to be present in practice. A criticism of Alshetwi's (2017) study is that he relies on ROA as the only firm performance measure. However, accounting measures may not be as accurate because they are yearly data and their reporting is controlled by managers.

Alhussayen and Shabou (2016) investigate the role of intensive board monitoring using the audit and nomination and remuneration committees in listed Saudi firms as proxies for protecting firm resources and analyse their relationship with firm value using OLS regressions; they also exclude banking and insurance firms. Firm value is measured with Tobin's $\mathrm{Q}$ and the market-to-book ratio. They find intensive board monitoring has a significant and positive impact on firm value. The results are made robust using the two-stage least squares (2SLS) method to account for the endogenous nature of the intensive board monitoring variables. A criticism of Alhussayen and Shabou (2016) is that Tobin's Q and the market-to-book ratio are similar performance measures. Furthermore, banking and insurance firms were excluded because their characteristics are different from those in other sectors, although it is unclear how this would have affected the findings. The model used by Alhussayen and Shabou (2016) includes ROA as an independent control variable, which is likely to be endogenously related to the dependent performance measures since both simultaneity and reverse causality can affect the dependent variable. Although Alhussayen and Shabou (2016) use the 2SLS method, this too can be sensitive to and influenced by the instrument.

Almoneef and Samontaray (2019) argue that many studies exclude the banking sector from their analyses; thus, they focus exclusively on the banking sector. The authors investigate the impact of corporate governance on the performance of Saudi banks from 2014 to 2017. Their analysis of corporate governance includes measures of board size, board meetings, number of board committees, board independence, foreign board membership, audit committee size and audit meetings, and audit committee independence. Using panel data with ROA, ROE, and Tobin's Q as performance measures, the study shows that board size, audit committee meetings, and bank size have a positive impact on ROE, whereas board independence has a negative effect. Similarly, board and bank sizes have a positive relationship with ROA, while board meetings have a negative relationship. Furthermore, board size, board independence, and bank size have a positive relationship with Tobin's Q, whereas the number of board committees and bank age have negative ones. Finally, audit committee size, audit committee independence, and foreign board membership have no 
impact on bank performance. Prior to this, Alhassan et al. (2015) examine the performance of 10 listed Saudi banks using three corporate governance mechanisms as determinantsboard size, board composition, and board meetings-between 2007 and 2012 with 60 data points in an OLS regression. The study period is chosen to investigate the 2006 corporate governance code. The authors find a non-significant positive relationship between board size and firm performance. However, board composition and firm performance show no significant relationships, while board meetings and firm performance display positive relationships. The results of Almoneef and Samontaray (2019) and Alhassan et al. (2015) appear to be mixed in their support for each other and with past studies for consistency and comparison. Al-Sahafi et al. (2015) investigate 11 Saudi banks between 2009 and 2012. They focus on the effects of board size, board independence, audit committee, and CEO status on ROA, ROE, and Tobin's Q between 2009 and 2012. Board size shows mixed results, but board independence has a significantly positive relationship with performance. Moreover, the leverage ratio has a significantly negative relationship with performance. CEO status and audit committee size and independence have no significant relationship with bank performance.

Bahrawe et al. (2016) review the relevant literature and theoretically study the corporate governance mechanisms in Saudi Arabia. The proposed theoretical framework explains the relationship between corporate governance mechanisms, such as audit committees, boards of directors, and audit independence. The paper descriptively explores Saudi corporate governance reforms and the Saudi auditing market, arguing that regulatory authorities should focus more on improving the awareness and appreciation of effective corporate governance through internal mechanisms, such as the audit committee and board of directors, as well as by external mechanisms such as external auditors. Marai et al. (2016) also conduct a literature review, while Al-Sager and Samontaray (2018) employ a questionnaire to study corporate governance concepts and the importance of board size, board composition, board committees, and ownership structure. They study corporate governance awareness using the gender of Saudi investors and its impact on their investment decision making. Fallatah (2015) studies listed Saudi firms between 2008 to 2012 regarding board size, board independence, CEO duality, government ownership, and whether CEO compensation is related to firm performance. The study finds CEO compensation is negatively related to board independence, and higher CEO compensation results in improved firm performance.

Hamdan (2018) considers foreign ownership a moderator variable and studies the impact of foreign ownership on board interlocking, that is, the presence of directors with more than one directorship, and firm performance. The sample includes 131 Saudi firms in 2016 only, and ROA and ROE are used as performance measures. The results show that the effectiveness of the directors' monitoring role decreases as the number of interlocks per director increases. Furthermore, foreign firms have a positive impact on turning around the negative relationship between board interlocking and performance. Buallay et al. (2017) study corporate governance practices of 171 listed Saudi firms for 2012-2014, using ROA, ROE, and Tobin's $\mathrm{Q}$ as firm performance measures. The control variables include firm size, firm age, auditing quality, board size, and an industry dummy to investigate the relationship between corporate governance practice and performance. They find no significant impact of adopting corporate governance, and board independence displays no significant relationship with firm performance. However, board size has a significant impact on firm performance. To capture these interactions, I hypothesise that: 
Hypothesis 1 There is a positive relationship between board composition/independence of listed Saudi firms and performance.

Hypothesis 2 An exogenous shock on Saudi board regulations is more likely than not to have a positive impact on firm performance.

Hypothesis 3 A firm's lagged past performance (a proxy for endogenous factors) affects current firm performance, which in turn impacts the board composition-performance relationship.

Hypothesis 4 The increased monitoring costs of Saudi firms are likely to have a negative and decisive impact on firm performance.

Hypothesis 5 Managerial pay is likely to have a positive impact on firm performance.

In light of the literature reviewed to this point, this study fills a gap in the current literature in the following ways. First, I contribute to the literature on board composition, board independence, and managerial pay using data from listed Saudi corporations for 2007-2014, which has not been examined. Second, I examine the exogenous impact of changes in board regulation, given that exogenous impacts tend to be rare occurrences. This issue has been considered so important that it has been advised it should be taken into account when modelling a corporation's environment. Finally, the study extends previous studies that utilise cross-sectional regressions by employing panel data.

\section{Data and variables}

To examine the effects of board composition and managerial pay on firm performance, as well as the impact of board-monitoring costs on firm performance, this study employs a unique panel dataset consisting of 169 listed Saudi firms for 2007-2014 and variables relating to board composition, director incentives, CEO and top executive pay, and CEO share ownership. The sample is considered as a whole. Data were obtained from the CMA and Mubasher. I was unable to obtain data on corporate governance variables prior to 2007 from the CMA, partly due to a 1:5 stock split in 2006. Other data used in this study were obtained from the annual reports of the 169 publicly listed Saudi firms and Bloomberg. All variables with a monetary value are in Saudi Riyal, which is pegged to the United States dollar (USD) at a rate of 3.75 .

\subsection{Dependent variables}

Table 1, Panel A describes the four performance measures used (ROA, ROE, Tobin's $Q$, and Stock Returns) to determine whether the results are sensitive to specific measures and to check for consistency. Note that $R O A$ and $R O E$ are accounting-based performance measures that are backward looking (Shan and McIver 2011), while Tobin's $Q$ and Stock Returns are forward-looking market-based measures that capture the value placed by investors on future firm prospects. Although these performance measures are related, they can yield different results, especially if they are affected by factors such as corporate governance, liquidity, or share price (Demsetz and Villalonga 2001; Morck et al. 1988). Of the 


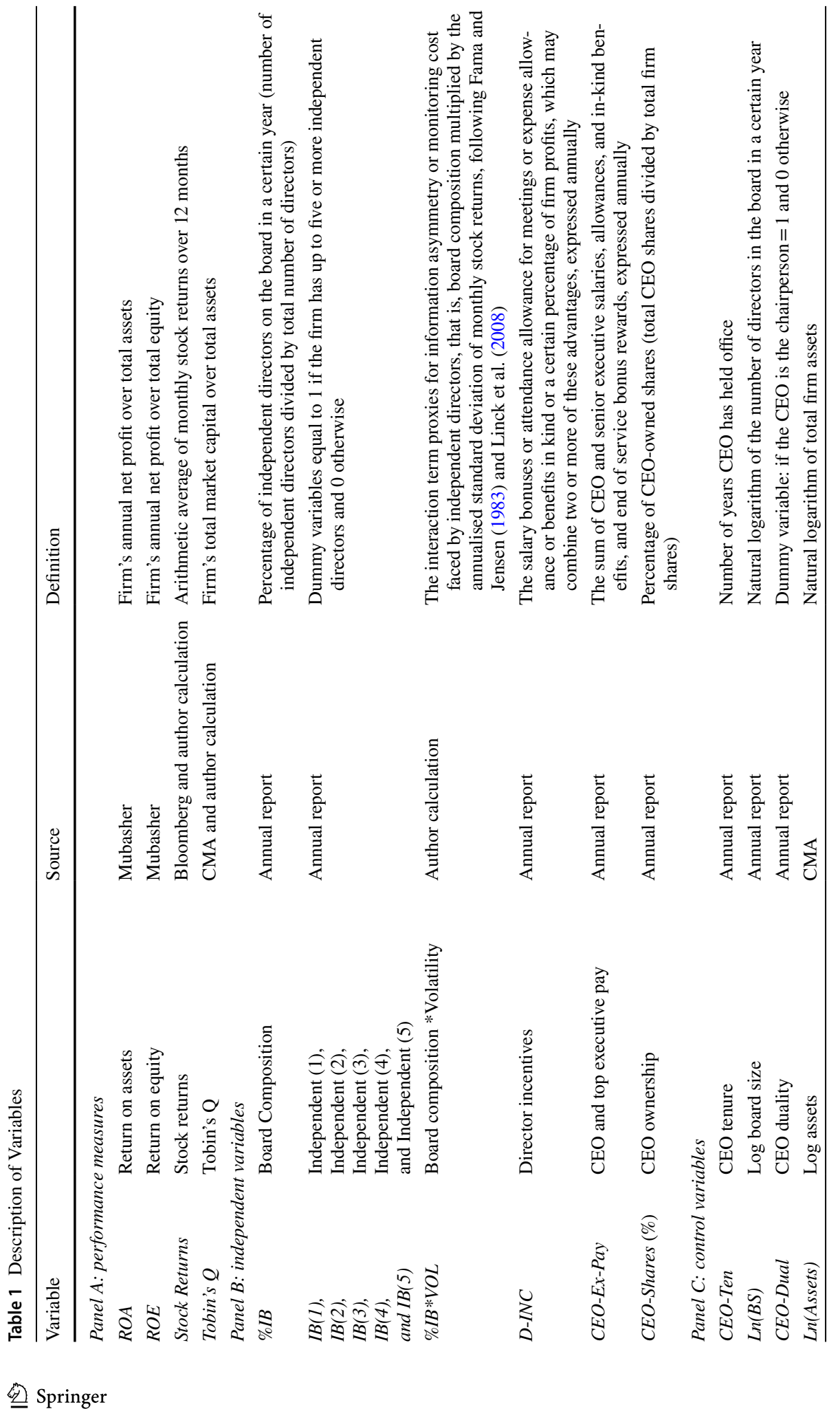




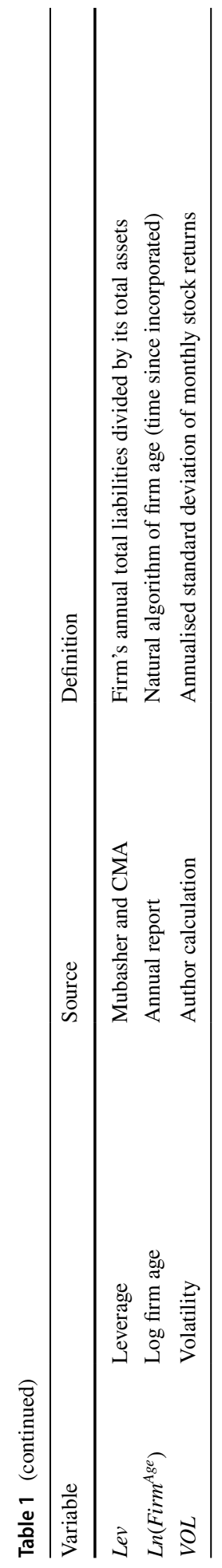


performance measures used in this study, Tobin's $Q$ is said to be problematic in corporate governance studies because it is defined as a proxy for future growth opportunities, thus describing value that is a cause rather than a consequence of the corporate governance structure (Boone et al. 2007; Lehn et al. 2009; Linck et al. 2008). However, Morck et al. (1988) argue that Tobin's $Q$ reflects firms' intangible assets better than operating performance, which may not fully capture market expectations resulting from reforms, especially when there are changes in corporate governance structure and regulations. As a result, I include Tobin's $Q$ for comparison and robustness and, for the purpose of analysis, select four performance measures as suggested by the corporate governance literature to enable comparisons while accounting for the sensitivity of the results to the performance measure used.

The study employs panel data, in light of Murphy's (1985) remark that cross-sectional models are inherently flawed due to a lack of theoretical basis for relevant variables and because of the likelihood of omitted variables. It is worth noting that if omitted variables are presumed not to change over time, it is possible to accurately evaluate the relationship by analysing time-series regressions. Since the data used are for 2007-2014, there is a maximum of eight observations for each firm or executive. Furthermore, it would be laborious and not instructive to estimate separate regressions for each executive in the 169 firms. Murphy (1985) also notes that regression intercepts represent ability and historical performance, among others, which should vary systematically across executives. In this study, there are no ex-ante reasons to suspect that performance coefficients would differ between individuals or firms. For the same reason, I assume that the relationships of pay sensitivity and board composition with performance will be the same for all executives and firms.

\subsection{Independent variables}

Table 1, Panel B describes the independent variables. Saudi board directors can be classified as executive directors, who are employed full-time by the firm and receive a salary; non-executive directors, who do not work full-time for the firm or receive full-time salaries; and independent directors, who are totally independent from the firm. Non-independence is said to exist for directors who meet one of the following criteria. First, a director who owns $5 \%$ or more of the shares in the firm or its subsidiaries or represents, in a legal capacity, another individual who owns $5 \%$ or more shares in the firm or its subsidiaries is considered non-independent. Non-independence may also be said to exist if, in the past two years, a director was a senior executive in the firm or its subsidiaries or if the board member was employed in another company associated with the firm. Finally, non-independence also exists when a director in a subsidiary company is nominated for the holding firm's board or directors are related to other board members. The 2009 regulation required that the majority of the board include non-executive members and the number of independent directors be equal to at least two or one-third of the total number of board members, whichever is greater (CMA 2017).

It is worth mentioning that I do not examine the role of the audit committee due to the common perception in Saudi Arabia that audit committees lack expertise, do not have close working relationships with either external or internal auditors, are lacking in independence, and do not perform an effective role in many listed Saudi corporations. In view of this, it would have been useful to conduct interviews with external and internal auditors to obtain a deeper understanding of how the auditing role has evolved in listed Saudi firms since the 
corporate governance code was implemented. However, this research is not directly related to the current study's focus and is left for future work.

\subsection{Control variables}

It is widely known that control variables can influence and thus correlate with firm performance. Therefore, including control variables is expected to improve estimates, while also eliminating the omitted variable bias that has been noted to affect previous studies; see MacAvoy et al. (1983), Baysinger and Butler (1985), and McConnell and Servaes (1990) for details. In consideration of the advice in these studies, I utilise the control variables in Table 1, Panel C. Note that the natural logarithm of ASSETS as a measure of firm size means larger firms are more likely to have a higher number of outside directors on their boards because they require more outside expertise and because they tend to benefit from more extensive monitoring and evaluation. $\operatorname{Ln}(B S)$ can be negative, as an increase in the number of board members can increase agency costs, reduce efficiency, and detract from firm performance (Jensen 1993; Lipton and Lorsch 1992; Yermack 1996). Natural logarithms are used for three reasons: to simplify the interpretation of the results; according to Murphy (1985), to reduce the level of skewness in the size distribution of firms; and to transform the data from bounded to unbounded, as Demsetz and Lehn (1985) note.

I do not use ownership variables because the disclosure and transparency for the corporate governance code began in 2008 and was not available in Saudi Arabia before this date. This study uses annual data from 2007 to 2014; in addition, the ownership data is available only for large owners with more than 5\% ownership and some companies do not have any shareholders who own more than 5\% (CMA 2017).

\section{Methodology}

To examine the impact of board composition and managerial pay on firm performance, I apply five empirical approaches: RE, FE, DID, dynamic GMM based on the work of Arellano and Bond (1991), and instrumental variables two-stage least squares (IV-2SLS). The FE model considers endogeneity from unobserved time-invariant heterogeneities; however, it does not resolve endogeneity issues arising from time-varying heterogeneities, reverse causality, or simultaneity (Conyon and He 2011). The rationale behind the RE approach is that, unlike the FE method, the variation in the error term or unobserved variables is assumed to be random and not correlated with the predictor or independent variables in the regression model. Moreover, they are more strongly statistically independent from observed variables and predictors. The RE method uses partial pooling, whereas the FE one does not. Note that the choice of either approach can be determined by the Hausman (1978) test. For partial pooling, there are fewer data points, and the coefficient estimates are partially based on the more abundant data from other groups. This could be more advantageous than either pooling all groups together (which could hide group-level variation) or estimating the effects separately for all groups (which could result in poor estimates for low-sample groups). The random effects model extends the partial pooling technique as a general statistical model, which allows the approach to be used in various contexts. The RE and FE models are expressed as follows: 


$$
\begin{aligned}
\text { PERF }_{i t}= & \alpha+\beta_{1} \% I B_{i t}+\beta_{2} \operatorname{Ln}(B S)_{i t}+\beta_{3} C E O-\text { Dual }_{i t}+\beta_{4} \operatorname{Ln}(\text { Assets })_{i t} \\
& +\beta_{5} \text { Lev }_{i t}+\beta_{6} \operatorname{Ln}\left(\text { Firm }^{\text {Age }}\right)_{i t}+\beta_{7} \text { VOL }_{i t}+\varepsilon_{i t} .
\end{aligned}
$$

To check the robustness of the results, I apply the following equation, which indicates the percentage of independent board members:

$$
\begin{aligned}
& \text { PERF }_{i t}=\alpha+\beta_{1} \% I B 33.33-50_{i t}+\beta_{2} \% I B>50_{i t} \\
& +\beta_{3} \operatorname{Ln}(B S)_{i t}+\beta_{4} C E O-D_{u a l}+\beta_{5} \operatorname{Ln}(\text { Assets })_{i t} \\
& +\beta_{6} \text { Lev }_{i t}+\beta_{7} \operatorname{Ln}\left(\text { Firm }^{\text {Age }}\right)_{i t}+\beta_{8} \text { VOL }_{i t}+\varepsilon_{i t} \text {. }
\end{aligned}
$$

An additional test for robustness is carried out to gauge board independence by number and not by percentage as follows:

$$
\begin{aligned}
\text { PERF }_{i t}= & \alpha+\beta_{1} I B(1)_{i t}+\beta_{2} I B(2)_{i t}+\beta_{3} I B(3)_{i t} \\
& +\beta_{4} I B(4)_{i t}+\beta_{5} I B(5)_{i t}+\beta_{6} \operatorname{Ln}(B S)_{i t}+\beta_{7} C E O-\text { Dual }_{i t}+\beta_{8} \text { Ln }\left(\text { Assets }_{i t}+\beta_{9} \text { Lev }_{i t}\right. \\
& +\beta_{10} \operatorname{Ln}\left(\text { Firm }^{A g e}\right)_{i t}+\beta_{11} V_{\text {OOL }}+\varepsilon_{i t} .
\end{aligned}
$$

The financial test for robustness seeks to determine whether the monitoring cost affects firm performance and is expressed as follows:

$$
\begin{aligned}
\text { PERF }_{i t}= & \alpha+\beta_{1} \% I B_{i t}+\beta_{2} \% I B * V O L_{i t}+\beta_{3} \operatorname{Ln}(B S)_{i t}+\beta_{4} C E O-\text { Dual }_{i t} \\
& +\beta_{5} \text { Ln }(\text { Assets })_{i t}+\beta_{6} \text { Lev }_{i t}+\beta_{7} \operatorname{Ln}\left(\text { Firm }^{\text {Age }}\right)_{i t}+\beta_{8} V O L_{i t}+\varepsilon_{i t} .
\end{aligned}
$$

The empirical test for managerial pay using RE and FE is as follows:

$$
\begin{aligned}
& P_{E R F_{i t}}=\alpha+\beta_{1} D-I N C_{i t}+\beta_{2} C E O-E x-P_{i t}+\beta_{3} C E O-\text { Shares }_{i t} \\
& +\beta_{4} C O E-T_{e n}+\beta_{5} C E O-D_{u a l}+\beta_{6} \operatorname{Ln}(B S)_{i t} \\
& +\beta_{7} \text { Ln }(\text { Assets })_{i t}+\beta_{8} \text { Lev }_{i t}+\beta_{9} \operatorname{Ln}\left(\text { Firm }^{\text {Age }}\right)_{i t}+\beta_{10} V_{O L} L_{i t}+\varepsilon_{i t} \text {. }
\end{aligned}
$$

For Eqs. (1)-(5), the variables are defined as follows: $Q$.

$P E R F_{i t}=$ dependent variable that refers to either ROA, ROE, Stock Returns, or Tobin's

The independent variables are as follows:

$\% I B=$ board composition as a percentage of the independent directors on the board.

$\% I B$ 33.33-50= board composition as a percentage of the independent directors on the board above $33.33 \%$ and below or equal to $50 \%$.

$\% I B>50=$ board composition as a percentage of the independent directors on the board above $50 \%$.

$I B(1), I B(2), I B(3), I B(4), I B(5)=$ the number of independent members on the board, grouped as one, two, three, four, and five or more.

$\% I B * V O L=$ monitoring cost.

$D-I N C=$ director incentives (Saudi riyals, SAR).

$C E O-E x-P a y=\mathrm{CEO}$ and top executive pay (SAR).

$C E O$-Shares $=$ percentage of CEO-owned shares.

The control variables used in this study are as follows:

$C E O-T e n=\mathrm{CEO}$ tenure.

$\operatorname{Ln}(B S)=\log$ board size.

$C E O-$ Dual $=$ CEO duality.

Ln(Assets $)=$ natural logarithm of firm total assets. 
Lev $=$ leverage.

$\operatorname{Ln}\left(\right.$ Firm $\left.^{\text {Age }}\right)=$ natural logarithm of firm age since incorporated.

$V O L=$ volatility.

These variables are explained in more detail in the data section.

\subsection{Difference-in-differences approach}

Generally, the DID method is used in finance and economics to address the endogeneity problem; see Bertrand and Mullainathan (2003) for details. The DID model generates two variables. The first is a dummy variable for the post-regulation years from 2009 until 2014. I describe this indicator variable as 'post-regulation'. The treated variable is also a dummy variable that equals 1 if the proportion of independent directors on a board is greater than or equal to one-third and 0 otherwise. I refer to this variable as 'treated' and then multiply 'post-regulation' with 'treated' to produce a new variable that captures the effect of the differences between firms that implemented and enforced the corporate governance regulations after 2008 and those that did not. Including the variable 'Treated ${ }^{*}$ Post regulation' and firm-fixed effects eliminates any bias from comparing the treatment and control groups that may have resulted from the differences in groups over time. This requires the listed Saudi firms in the sample to exist before the exogenous shock of the change in Saudi corporate regulations (i.e. by the end of 2008). This condition requires excluding 43 out of the sample of 169 listed Saudi firms. I did not include time dummies (time fixed effects) in the models for macroeconomic shocks affecting all firms because I do not want to increase the number of predictors vs sample size. There are some missing observations for some firms and some years, so adding time dummies (increasing explanatory variables) may affect the significance of the estimates.

This study also analyses the exogenous shock of the Saudi corporate governance regulation by comparing firm performance in the treatment group, which was affected by the change in corporate governance regulation, with firm performance in the control group, which was not affected. Note that endogeneity issues are reduced because changes in the board composition of Saudi firms would be a result of the change in corporate governance regulation, as opposed to being endogenously determined by firm characteristics. In this respect, the corporate governance regulation change in Saudi Arabia created conditions that allow studying the relationship between board composition and performance using the following model:

$$
\begin{aligned}
& P_{E R F_{i t}}=\alpha+\beta_{1} D_{I D}+\beta_{2} \operatorname{Ln}(B S)_{i t}+\beta_{3} C E O-\text { Dual }_{i t} \\
& +\beta_{4} \operatorname{Ln}(\text { Assets })_{i t}+\beta_{5} \text { Lev }_{i t}+\beta_{6} \operatorname{Ln}\left(\text { Firm }^{\text {Age }}\right)_{i t}+\beta_{7} V O L_{i t}+\varepsilon_{i t} \text {. }
\end{aligned}
$$

\subsection{Dynamic generalised method of moments estimator}

In addition to the above empirical methods, I also use the dynamic GMM estimator, which integrates the dynamic nature of internal corporate governance choices or independent variables with the historical values of the dependent variable (performance). This approach is a valid and powerful instrument that addresses simultaneity and time-invariant unobserved heterogeneity, which enables us to identify causal relationships as well as reverse causality between governance and performance. The GMM estimator advances the GLS or traditional FE estimation in at least three ways. First, unlike GLS methods, GMM can 
include firm fixed effects that account for time-invariant unobserved heterogeneity. Second, unlike traditional FE estimation, GMM enables existing governance to be influenced by past realised performance. Finally, unlike GLS or traditional FE, if the underlying process is dynamic, GMM allows for combining past firm variables as instruments to account for simultaneity. Therefore, a key feature of the GMM method is its reliance on a set of internal instruments (i.e. past performance figures and/or values of governance used as instruments for current realisations). This eliminates the requirement for external instruments. However, not all endogeneity issues are solved using dynamic GMM estimation and its reliance on the lag of dependent or independent variables is an empirical trade-off. Weak instruments can potentially become stronger as the lag length increases, thus making them more exogenous. This assumes that the error term is not serially correlated, which is unlikely to hold for all variables used in this empirical investigation. In this regard, Griliches and Hausman (1986) note that panel data estimators can magnify the bias from errors. Further, since GMM relies partly on first differences, it might not fully remove bias from measurement errors unless strong assumptions are made about the serial correlation of measurement errors, which would be difficult to verify.

Using lags requires assumptions about minimum weak rational expectations, which are not without implications. For example, if investors trade off the anticipated board structure, any shocks to current firm performance must have been unanticipated. Therefore, past firm information for $p$ time periods should be included in today's performance, and $p$ lag lengths of past performance should be sufficient to capture the influence on current performance. Therefore, any firm information older than the included lag will be exogenous and have no direct impact on current or future performance, as noted by Muth (1961) and Lovell (1986). In other words, unpredicted changes in future performance are treated as expectational error, which implies that empirical models include all variables that could jointly impact the dependent and independent variables (Hansen and Singleton 1982). However, this is unlikely to be the case because of the imperfect nature of proxies in empirical tests. It is possible that regressions with corporate governance as a performance variable are misspecified and the time-varying unobserved variables are already omitted, which may affect both corporate governance and performance. Therefore, to justify their use in dynamic panel data estimation, inferences from empirical tests that examine the strength of lagged instruments must be made with caution. However, if the underlying process is dynamic, even with such weaknesses in specification tests, the dynamic GMM estimation is likely to dominate inferences from GLS or traditional FE estimation, which are not generally accompanied by specification tests.

To obtain consistent, unbiased estimates, I employ the GMM estimator to explore the dynamic relationships of board composition and managerial pay with firm performance. Potential bias from fixed, unobserved heterogeneity is eliminated by first-differencing, that is, taking the lag of the dependent variable. It is crucial to include sufficient lags in performance to incorporate all past information and control for the dynamic nature in the empirical relationship. If this is not done, the model may still be misspecified due to omitted variable bias. Since the structure of the board is persistent, it reduces the power of panel data estimates and ensures errors are not correlated. Note that Glen et al. (2001), Zhou (2001), Gschwandtner (2005), and Wintoki et al. (2012), suggest that two-year lags would be sufficient to capture the persistence in performance. My model does not use an instrumental variable in GMM estimation; it only uses the lagged value of the independent variable as a covariate. This is due to the lack of evidence on the causal relationship between the instrumental variables and independent variables. If a variable whose lags are used as instruments is generated by a noncausal AR process, its lags may be endogenous and, hence, 
unsuitable as instruments, yielding an inconsistent GMM estimator (Lanne and Saikkonen 2011).

I also include control variables in the model to account for any time-varying heterogeneities or variables that might affect performance and corporate governance, although the model is likely to suffer from unobserved heterogeneity. As such, I assume that any correlations between corporate governance and control variables with unobserved effects are constant over time. This assumption is reasonable for shorter time periods, in which unobserved effects proxy for factors such as managerial ability. As previously noted, the dynamic GMM estimation also adds robustness to the results because it addresses the endogeneity arising from simultaneity, unobserved heterogeneity, and reverse causality. Compared to the DID and IV-2SLS models, the GMM is perhaps more useful, in that it addresses endogeneity using internal instruments as opposed to external ones or natural experiments, which may not be commonly occurring or available. Wintoki et al. (2012) note that GMM explicitly models the dynamic nature of the board independence-performance and pay-performance relationships using the firm's past performance as an independent regressor variable. The GMM models to be estimated are:

$$
\begin{aligned}
& P E R F_{i t}=\alpha+\beta_{1} \% I B_{i t}+\beta_{2} P E R F_{i t-2}+\beta_{3} \operatorname{Ln}(B S)_{i t}+\beta_{4} C E O-\text { Dual }_{i t} \\
& +\beta_{5} \operatorname{Ln}(\text { Assets })_{i t}+\beta_{6} \text { Lev }_{i t}+\beta_{7} \operatorname{Ln}\left(\text { Firm }^{\text {Age }}\right)_{i t}+\beta_{8} V_{O L}+\varepsilon_{i t} \text {. } \\
& P E R F_{i t}=\alpha+\beta_{1} D-I N C_{i t}+\beta_{2} C E O-E x-P a y_{i t}+\beta_{3} P E R F_{i t-2} \\
& +\beta_{4} C E O-\text { Shares }_{i t}+\beta_{5} C O E-\text { Ten }_{i t}+\beta_{6} C E O-\text { Dual }_{i t}+\beta_{7} \operatorname{Ln}(B S)_{i t} \\
& +\beta_{8} \operatorname{Ln}(\text { Assets })_{i t}+\beta_{9} \text { Lev }_{i t}+\beta_{10} \operatorname{Ln}\left(\text { Firm }^{\text {Age }}\right)_{i t}+\beta_{11} V_{O L}+\varepsilon_{i t} \text {. }
\end{aligned}
$$

In applying Eqs. (7) and (8), I first run the dynamic GMM estimation under the assumption of homoscedasticity using the one-step GMM estimator. To ensure that the dynamic GMM model is specified correctly, the Sargan over-identification test is then used to test the null hypothesis, $\mathrm{H}_{0}$, that over-identifying restrictions are valid. If the corresponding $p$-value is significant, I reject $\mathrm{H}_{0}$. This implies that the model should be reconsidered or that the instruments might suffer from misspecification unless I can attribute this rejection to heteroscedasticity in the data. If I do not reject the null hypothesis, the over-identifying restrictions are valid under the assumption of homoscedasticity using the one-step GMM estimator. Note that the Sargan test has an asymptotic Chi-squared distribution only for a homoscedastic error term. The one-step Sargan test over-rejects in the presence of heteroscedasticity. This is because its asymptotic distribution is not known under the assumption of a robust model using robust standard errors. ${ }^{1}$ Although there is an alternative two-step Sargan test, Arellano and Bond (1991) found a tendency for this test to under-reject in the presence of heteroscedasticity. For this reason, the Sargan test is computed for the one-step homoscedastic estimator.

Next, the one-step GMM estimator with robust standard errors, which is asymptotically robust to general cross-sectional and time-series heteroscedasticity, is estimated as a remedy to the heteroscedasticity problem, and the first- and second-order serial correlations in the first differenced errors are calculated. When the errors are independent and identically distributed, the first-differenced errors are serially correlated at an order of 1, as expected.

\footnotetext{
1 When using robust standard errors, serial correlation can be tested but the Sargan test statistic cannot be calculated (Arellano and Bond 1991), as Stata will not compute it.
} 
Therefore, the $\mathrm{H}_{0}$ of no autocorrelation is tested using the second order. If the $p$-value of the second order is not significant, the null hypothesis is not rejected, and there is no evidence of model misspecification. If the $p$-value is significant, it means autocorrelation exists in the error terms; thus, the null hypothesis of no autocorrelation is rejected.

\subsection{Instrumental variable: two stage least squares fixed effects}

It is widely recognised that a company's board of directors has a key supervisory role. Therefore, investigating the effect of director incentives and CEO and top executive pay on firm performance raises endogeneity concerns, since both can be determined by firm characteristics, and biases arise from simultaneity when compensation is determined jointly at equilibrium. Additionally, observable and uncontrollable factors could be responsible for the relationship between managerial pay and firm performance. Therefore, to delineate between endogeneity issues and simultaneity bias, as well as to highlight any causal relationships, the methodologies of Balestra and Varadharajan-Krishnakumar (1987) and Lahlou and Navatte (2017), who use the IV-2SLS approach, are followed, which allows consistent estimates under several conditions: when independent variables are correlated with the error term from omitted variables that affect both the independent and dependent variables; when there are changes in the influence of the dependent variable values on the explanatory variables (reverse causation); and when explanatory variables are subject to measurement error. Explanatory variables that are characterised by one or more of these issues are sometimes referred to as endogenous. In such situations, GLS regressions will be biased and produce inconsistent estimates. It should be noted that IV-2SLS utilises instrumental variables, which must satisfy two conditions in linear models. First, instruments should strongly correlate with endogenous explanatory variables; otherwise inferences based on parameter estimates and standard errors may be misleading. The second condition is orthogonality with the error term, that is, instruments cannot be correlated with the error term and should not exhibit the same issues as the original explanatory variables, as Roberts and Whited (2013) and Liu et al. (2015) note. Valid instruments induce changes in explanatory variables without having an independent impact on the dependent variable, which helps highlight the causal relationships between explanatory variables and the dependent variable. The IV-2SLS model applied is as follows:

First-stage regressions

$$
\begin{aligned}
& D-I N C_{i t}=\alpha+\beta_{1} \text { average } D-I N C_{i t}+\beta_{2}{\text { average CEO }-E x-P a y_{i t}} \\
& +\beta_{3} C E O-\text { Shares }_{i t}+\beta_{4} C O E-\text { Ten }_{i t}+\beta_{5} C E O \\
& - \text { Dual }_{i t}+\beta_{6} \operatorname{Ln}(B S)_{i t}+\beta_{7} \operatorname{Ln}(\text { Assets })_{i t}+\beta_{8} \text { Lev }_{i t}+\beta_{9} \operatorname{Ln}\left(\text { Firm }^{\text {Age }}\right)_{i t}+\beta_{10} V O L_{i t}+\varepsilon_{i t} \text {, }
\end{aligned}
$$

$$
\begin{aligned}
& C E O-E x-\text { Pay }_{i t}=\alpha+\beta_{1} \text { averageD }-I N C_{i t}+\beta_{2}{\text { averageCEO }-E x-P a y_{i t}} \\
& +\beta_{3} C E O-\text { Shares }_{i t}+\beta_{4} C O E-\text { Ten }_{i t}+\beta_{5} C E O-\text { Dual }_{i t}+\beta_{6} \operatorname{Ln}(B S)_{i t} \\
& \left.+\beta_{7} \text { Ln(Assets }\right)_{i t}+\beta_{8} \text { Lev }_{i t}+\beta_{9} \operatorname{Ln}\left(\text { Firm }^{\text {Age }}\right)_{i t}+\beta_{10} \text { VOL }_{i t}+\varepsilon_{i t} \text {, }
\end{aligned}
$$

Second-stage regressions 
Table 2 Correlation matrix for endogenous variables

\begin{tabular}{|c|c|c|c|c|c|}
\hline & & 1 & 2 & 3 & 4 \\
\hline 1 & $D-I N C$ & 1 & & & \\
\hline 2 & CEO-Ex-Pay & $\begin{array}{l}0.397 * * * \\
(0.000)\end{array}$ & 1 & & \\
\hline 3 & Average D-INC & $\begin{array}{l}0.475^{* * * *} \\
(0.000)\end{array}$ & $\begin{array}{l}0.400 * * * \\
(0.000)\end{array}$ & 1 & \\
\hline 4 & Average CEO-Ex-Pay & $\begin{array}{l}0.302^{* * * *} \\
(0.000)\end{array}$ & $\begin{array}{l}0.664 * * * \\
(0.000)\end{array}$ & $\begin{array}{l}0.635^{* * * *} \\
(0.000)\end{array}$ & 1 \\
\hline
\end{tabular}

*** represents significance at the $1 \%$ level. $P$-values are in parentheses

$$
\begin{aligned}
\text { PERF }_{i t}= & \alpha+\beta_{1} D-I_{\text {INC }}+\beta_{2} C E O-\text { Ex }_{i t} \text { Pay }_{i t}+\beta_{3} C E O-\text { Shares }_{i t} \\
& \left.+\beta_{4} C O E-\text { Ten }_{i t}+\beta_{5} C E O-\text { Dual }_{i t}+\beta_{6} \operatorname{Ln}(B S)_{i t}+\beta_{7} \text { Ln }_{\text {Assets }}\right)_{i t} \\
& +\beta_{8} \text { Lev }_{i t}+\beta_{9} \operatorname{Ln}_{\left(\text {Firm }^{\text {Age }}\right)_{i t}+\beta_{10} V O L_{i t}+\varepsilon_{i t} .}
\end{aligned}
$$

Using the IV-2SLS approach, Chen et al. (2010) find a positive impact on executive pay from global pay benchmarks, and Adams et al. (2011) point out that firm management compensation is likely to depend on the compensation paid by competitors in the same industry. For both these reasons, the industry averages for director incentives and for CEO and top executive pay are used as instrumental variables.

\section{Results and discussion}

Table 2 shows the correlation matrix for the endogenous variable and the average of the industry instrument variables discussed in Sect. 4. Note that the average variable value is correlated with the endogenous director incentives and CEO and top executive pay with correlations of 0.475 and 0.664 , respectively, as expected. Furthermore, industry average compensation is not expected to have a direct effect on individual firm performance.

Table 3 provides summary statistics of the variables used in this study. Very few Saudi firms in the sample have $I B(1)$ and $I B(2)$. That is, very few listed Saudi firms have one or two independent directors on the board or a CEO who also acts as chairperson. CEO-Dual is a dummy variable that equals 1 if there is CEO duality and 0 otherwise. The average Saudi CEO-Ten is just under six years with a median of four years. Generally, firm average performance is positive with larger standard deviations. Out of the 20 variables, 15 have standard deviations larger than the mean, which indicates the data for such variables are more widely spread.

In Table 4, Panels A and B show that the correlations between variables are not very strong. However, there is a strong understandable correlation between $R O A$ and $R O E$ (0.659), although the variables are not included in the same model. The following are also observed. First, a positive correlation exists between $R O A$ and $L n\left(F_{i r m}^{A g e}\right)(0.417)$, with a negative one between Tobin's $Q$ and Ln(Assets) (-0.574). The relationship between Tobin's $Q$ and Ln(Assets) will be always negative as Tobin's $Q$ is calculated by dividing a firm's market capital by its total assets. VOL and Stock Returns are also strongly correlated (0.673), which is theoretically expected. In Panel A, it is noticeable that managerial pay and CEO tenure are not highly correlated and, as expected, Ln(Assets) and CEO-Ex-Pay are 
Table 3 Summary statistics

\begin{tabular}{|c|c|c|c|c|c|c|}
\hline Variable & Observation & Mean & Median & Minimum & Maximum & $\begin{array}{l}\text { Standard } \\
\text { Deviation }\end{array}$ \\
\hline \multicolumn{7}{|c|}{ Panel A: performance measures } \\
\hline$R O A$ & 1146 & 4.151 & 3.202 & -77.540 & 43.980 & 10.587 \\
\hline$R O E$ & 1141 & 5.207 & 8.045 & -983.941 & 56.586 & 37.005 \\
\hline Stock returns & 1152 & 1.089 & 1.103 & -42.520 & 198.120 & 7.531 \\
\hline Tobin's $Q$ & 1146 & 2.039 & 1.331 & 0.131 & 16.927 & 2.228 \\
\hline \multicolumn{7}{|c|}{ Panel B: board independence } \\
\hline$\% I B$ & 1152 & 49.486 & 44.444 & 0 & 100 & 21.081 \\
\hline$I B(1)$ & 1152 & 0.008 & 0 & 0 & 1 & 0.088 \\
\hline$I B(2)$ & 1152 & 0.094 & 0 & 0 & 1 & 0.292 \\
\hline$I B(3)$ & 1152 & 0.310 & 0 & 0 & 1 & 0.463 \\
\hline$I B(4)$ & 1152 & 0.184 & 0 & 0 & 1 & 0.388 \\
\hline$I B(5)$ & 1152 & 0.373 & 0 & 0 & 1 & 0.484 \\
\hline \multicolumn{7}{|c|}{ Panel C: managerial pay } \\
\hline$D-I N C(S A R)$ & 1148 & $2,249,561$ & $1,705,000$ & 0 & $43,660,000$ & $3,001,603$ \\
\hline $\begin{array}{l}C E O-E x-P a y \\
\quad(S A R)\end{array}$ & 1060 & $7,654,556$ & $4,789,461$ & 0 & $72,095,000$ & $8,471,274$ \\
\hline CEO-Shares (\%) & 1123 & 0.918 & 0.001 & 0 & 45.501 & 3.738 \\
\hline \multicolumn{7}{|c|}{ Panel D: control variables for board composition and managerial pay } \\
\hline CEO-Ten & 1153 & 5.875 & 4 & 1 & 39 & 6.477 \\
\hline$B S$ & 1153 & 8.447 & 9 & 4 & 13 & 1.620 \\
\hline CEO-Dual & 1153 & 0.032 & 0 & 0 & 1 & 0.176 \\
\hline Ln(Assets) & 1148 & 21.359 & 21.133 & 17.200 & 26.798 & 2.060 \\
\hline Lev & 1136 & 14.998 & 4.665 & 0 & 126.473 & 18.993 \\
\hline Firm $^{\text {Age }}$ & 1153 & 23.660 & 22 & 1 & 89 & 16.365 \\
\hline Vol & 1144 & 11.859 & 9.639 & 0 & 280.184 & 11.672 \\
\hline
\end{tabular}

strongly correlated (0.620). In Panel B, board composition is correlated with $I B(1)-I B(5)$ and strongly correlated $(0.748)$ with board composition and $I B(5)$, although they are not included in the same model. $I B(5)$ and $I B(3)$ have a negative correlation $(-0.517)$.

Note that the number of listed firms was 111 in 2007 and reached 169 by the end of 2014; thus, the number of observations is not equal over time. In addition, some variables had some missing observations in some years for many reasons. First, some firms lost more than $50 \%$ of their capital, which led to suspension of trading in the Saudi stock exchange, resulting in some missing dates. Second, the 2006 corporate governance code applied to all companies listed on the Saudi stock exchange on a comply and explain basis. Initially, the code mostly served as a guideline for listed companies; however, it became mandatory in 2009 for the board and was extended to all variables in 2010. Thus, the required corporate governance information had to be disclosed by all listed companies. The summary statistics of the actual data used in the regression estimation are provided in Table 3.

Winsorizing was not used to compress distributions such as that of ROE, which had a range of -983.941 to 56.586 , because I was concerned about changing the data. I did not want to cause measurement error in the estimates only to deal with outliers that might cause missing data characteristics (Gujarati 2004). 


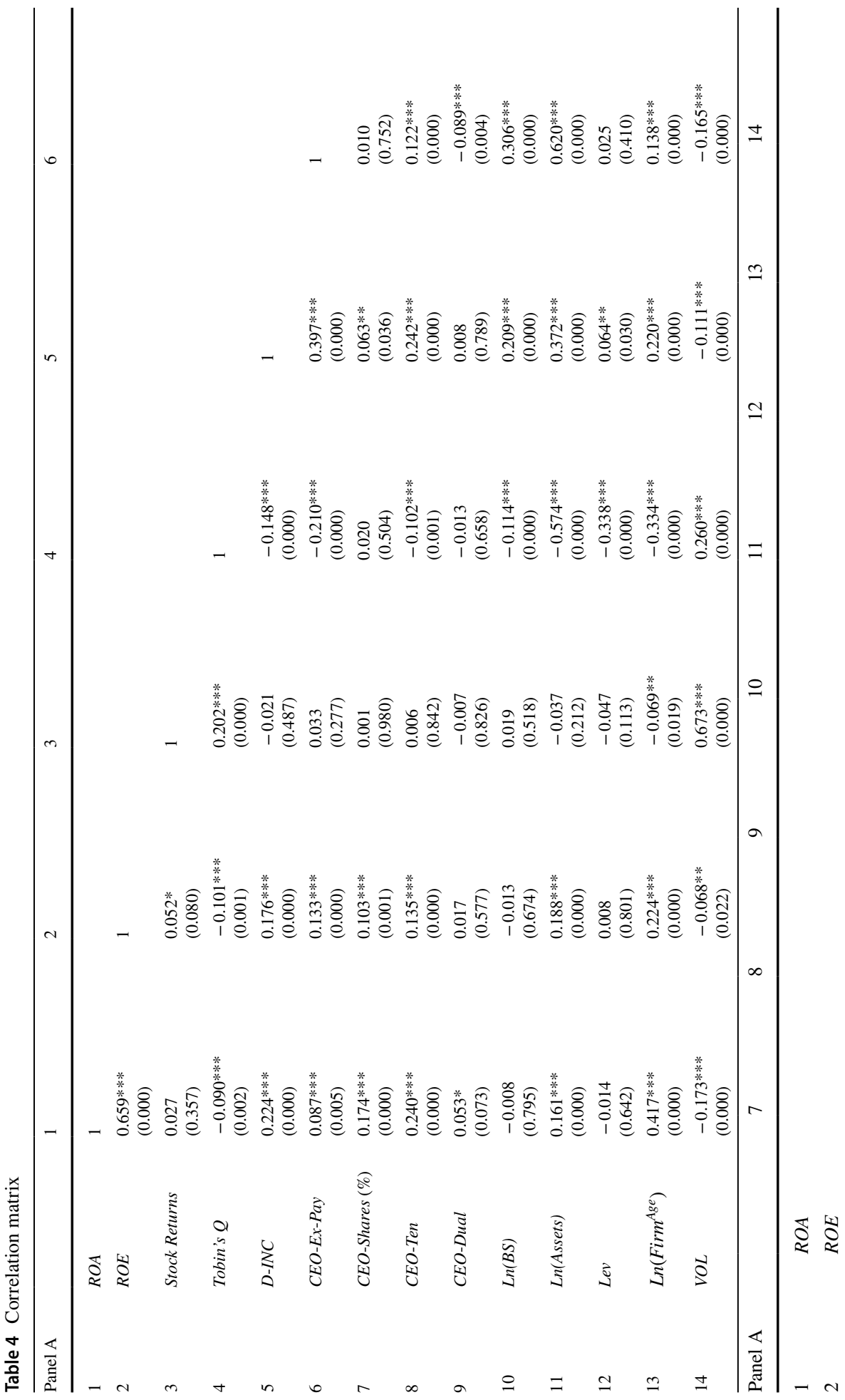




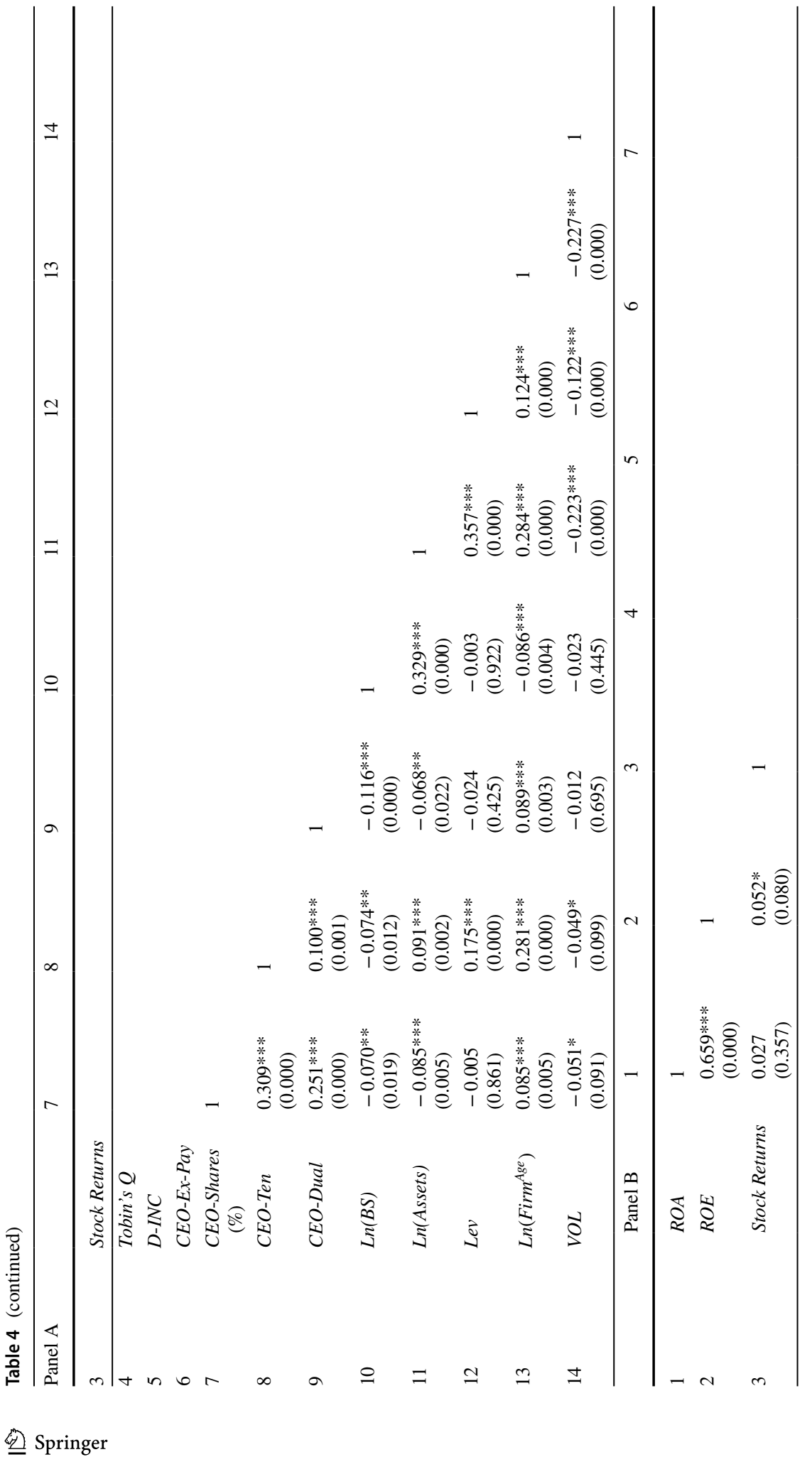




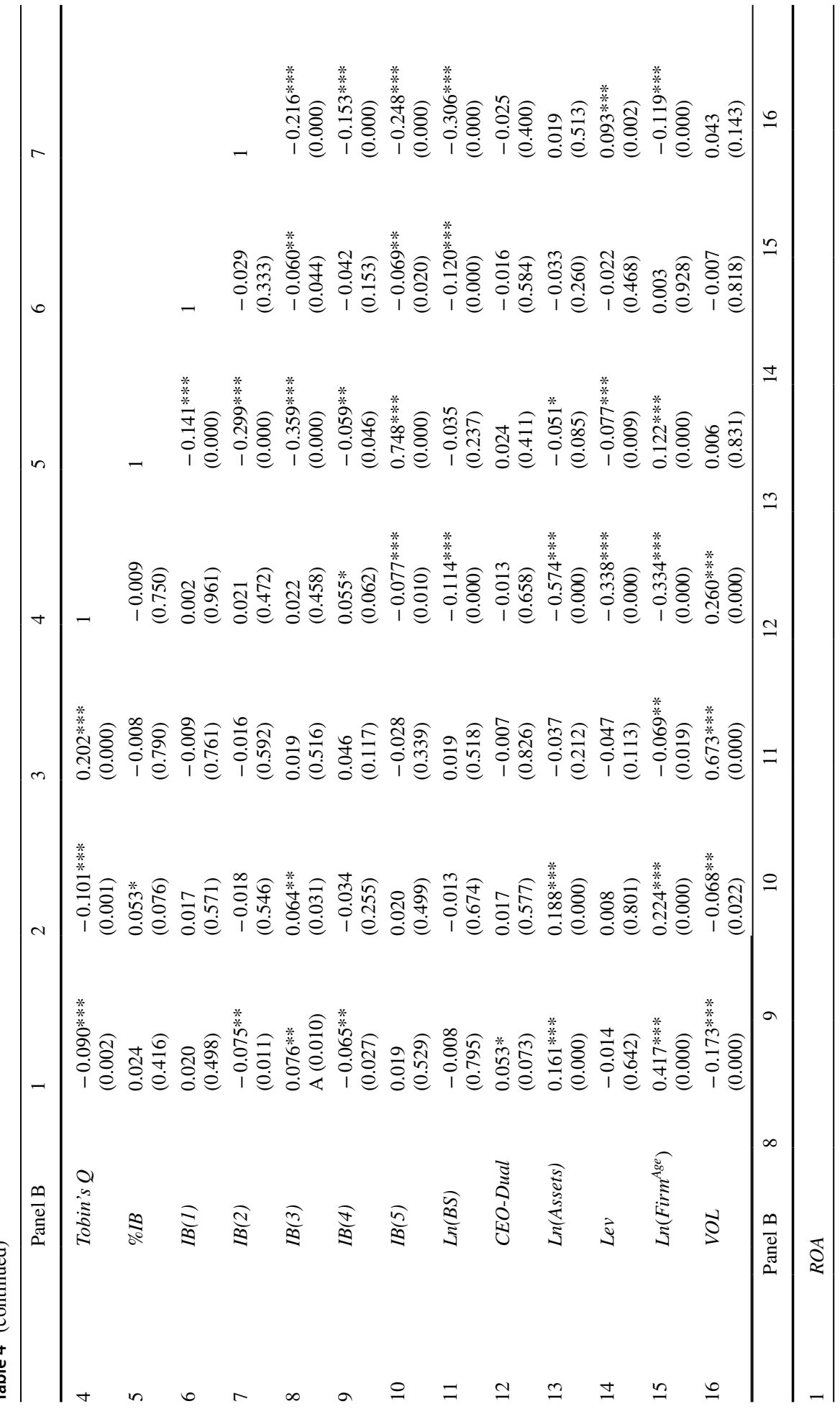




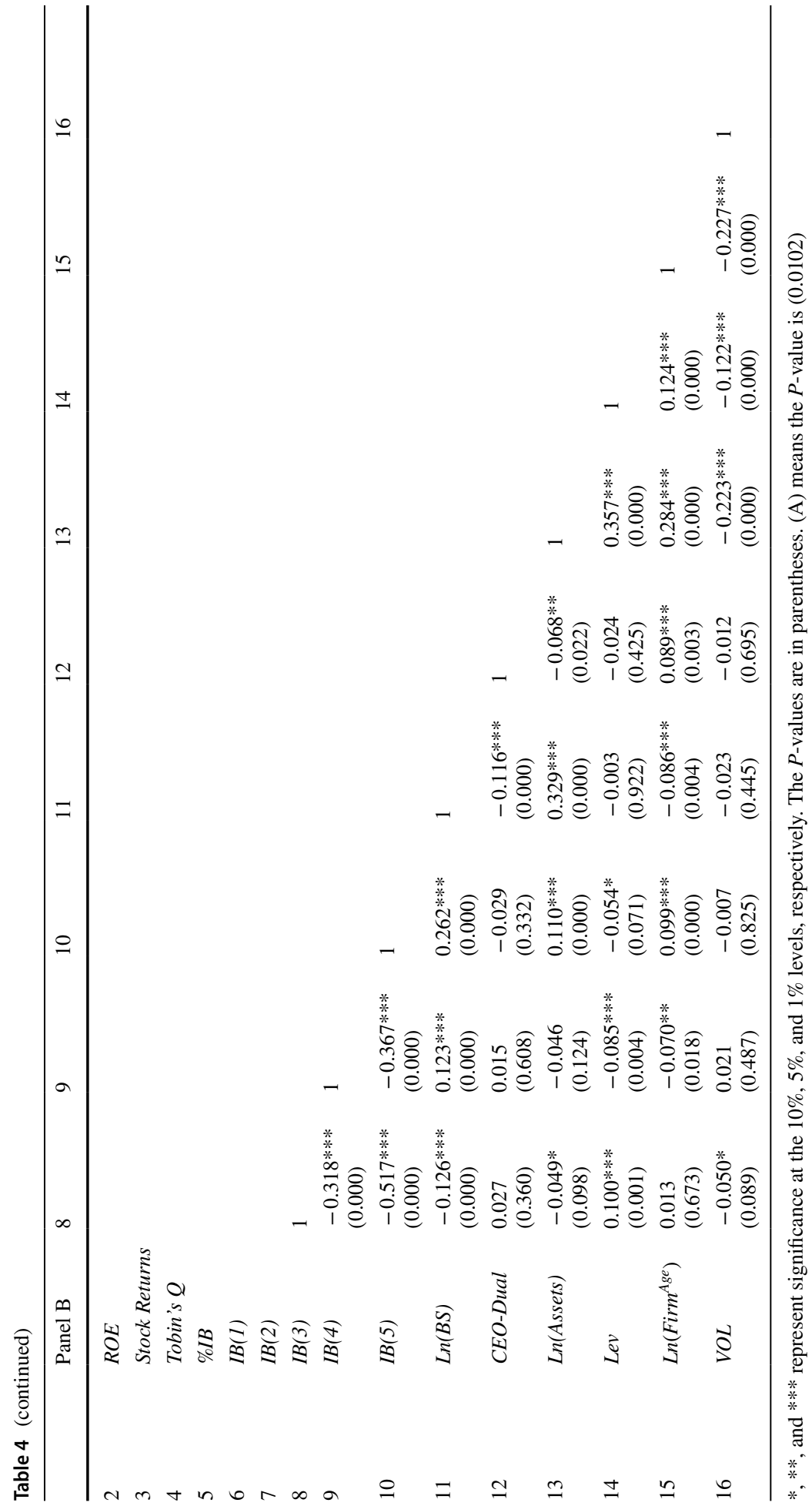




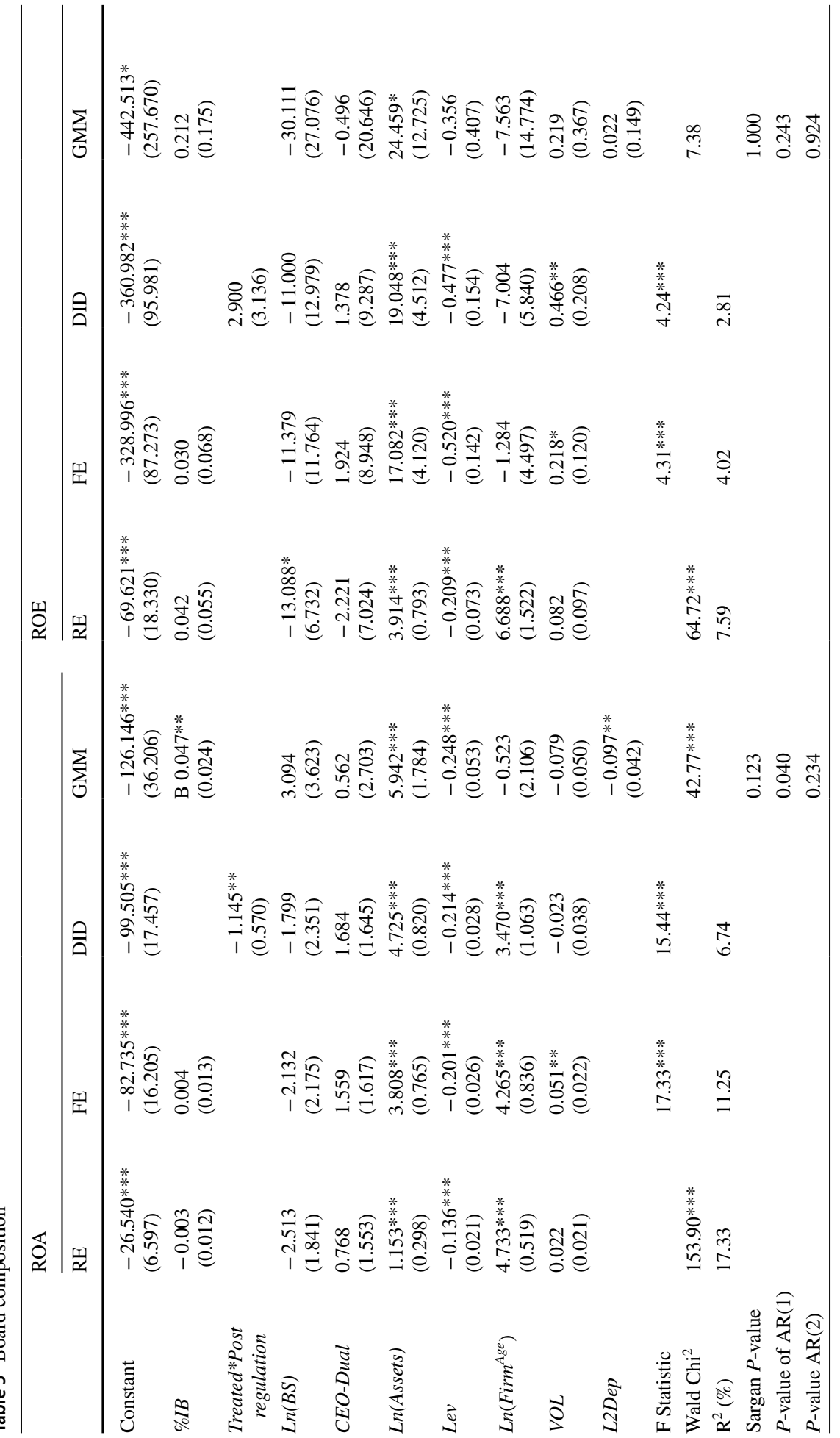




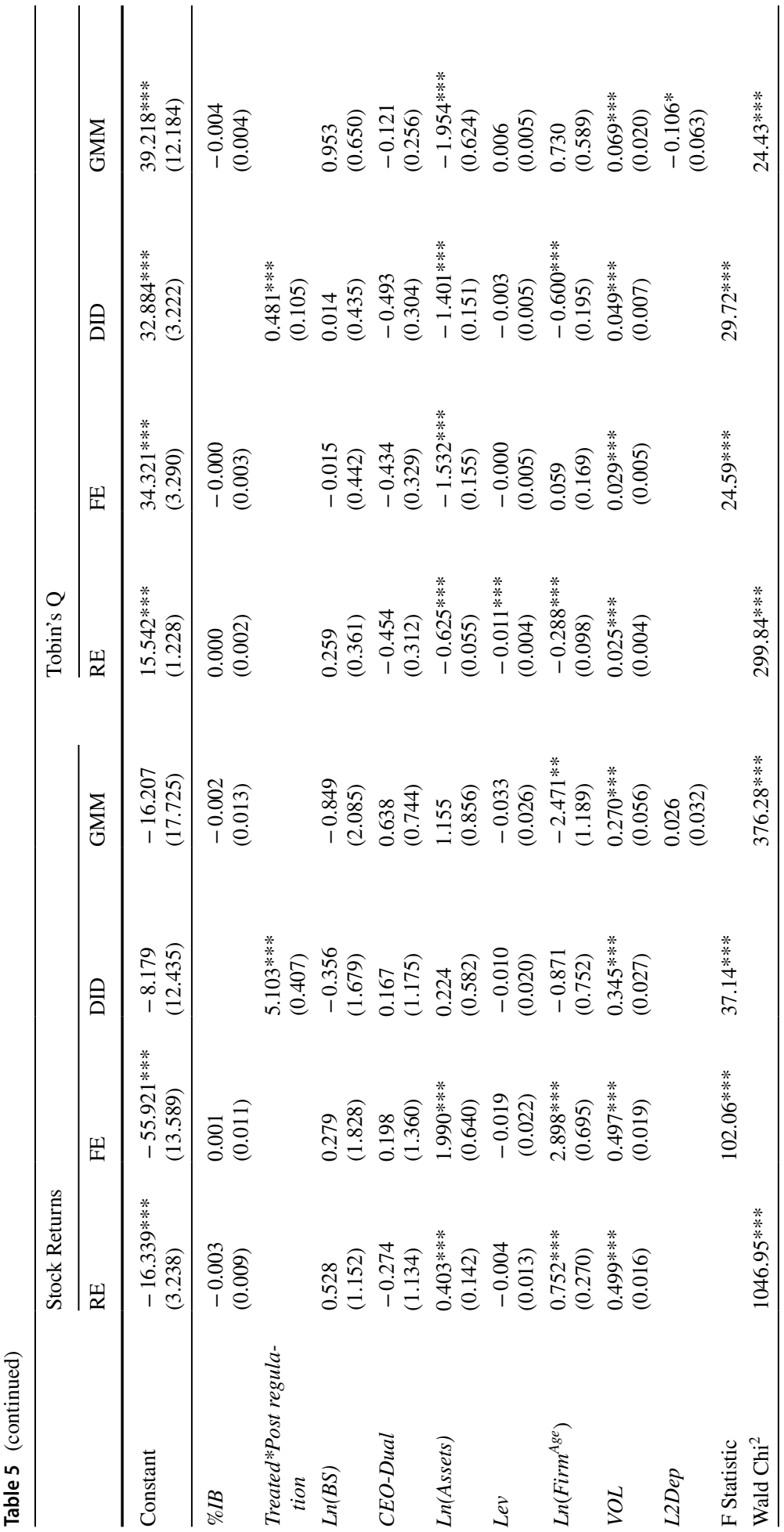




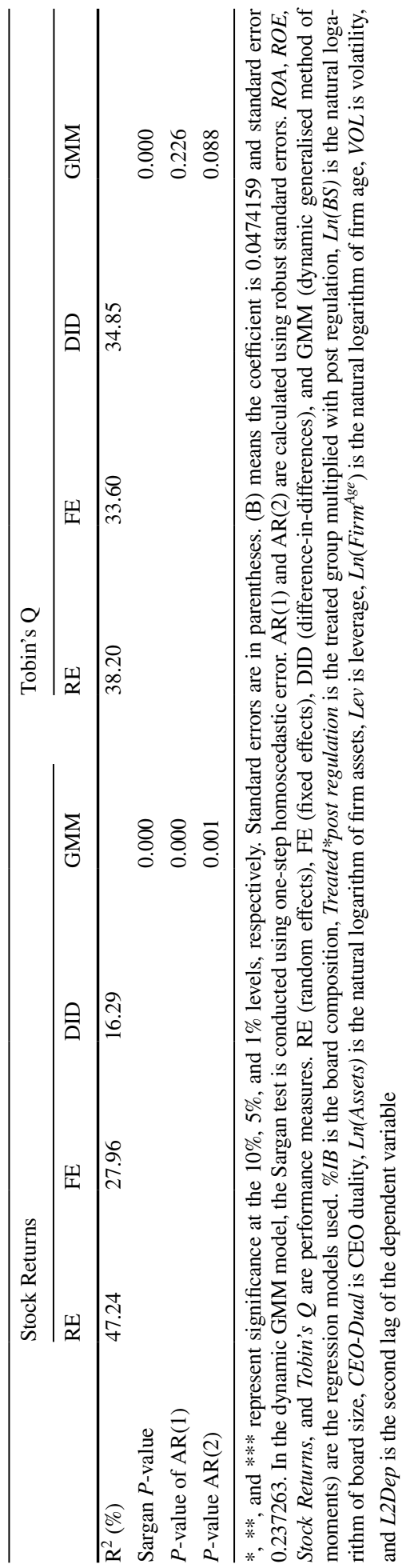


In Table 5, the RE model's board composition (\%IB) shows no significant relationship with the performance measures. The coefficients are not significant and are small, supporting the results reported by Black and Kim (2012) and Liu et al. (2015) (although their results were significant). Additionally, the FE model shows board composition has no significant relationship with the performance measures, which is opposite the findings of Liu et al. (2015) for ROA and ROE, Li et al. (2015) for ROA and Tobin's Q in their study of Chinese board independence and firm performance, and Black and Kim (2012) for Tobin's $\mathrm{Q}$ in their study of the effect of board structure on firm value using Korean data. Although there is no significance in the estimates, the $\% I B$ coefficients are similar in size and close to 0, which does not support Hypothesis 1 .

The results of the DID approach indicate that the performance measures (Stock Returns and Tobin's $Q$ ) yielded significantly positive performance differences of 5.103 and 0.481 , respectively, at the $1 \%$ significance level for listed Saudi firms that implemented post-2009 corporate governance regulations stipulating that at least two or one-third of directors must be independent, thus supporting Hypothesis 2. However, ROA shows a significantly negative relationship of -1.145 for listed Saudi firms, while $R O E$ displays no significant relationship between firms that implemented the corporate governance regulations and those that chose not to appoint independent board members, therefore not supporting Hypothesis 2. The lack of significance for $R O E$ and the negative relationship for $R O A$ might be because some firms chose not to obey the corporate governance regulation requirements and were instead willing to pay a fine of SAR 20,000-40,000. Another explanation might be the timing of the corporate governance regulation, since not all its components were implemented at the same time.

According to the annual reports, as the corporate governance regulations were implemented gradually and not on a date fixed by the government, they were gradually adopted by listed Saudi firms. Furthermore, shareholder ownership concentration is high. This is because many firms are family-owned and might thus might have been hesitant to adhere to the new regulations. Another possibility is that the results in Table 5 may be sensitive to different performance measures. These results are consistent with Black and Kim (2012), whose DID results show an increase in Tobin's Q for large Korean firms required to have a $50 \%$ share of independent directors on their board. This contradicts Moursli's (2020) finding of a negative impact on Tobin's Q. My results differ from those of Liu et al. (2015), who identified significantly positive relationships of ROA and ROE in the Chinese market, whereas there is a significantly negative relationship for $R O A$ and a non-significantly positive relationship for $R O E$. This might be due to this study's inclusion of only five years of data after the 2009 exogenous shock and only 169 listed Saudi firms, whereas Liu et al. (2015) had 10 years of data and a sample of 2,057 firms.

Turning to the dynamic GMM estimations, the lag of $R O E$ and Stock Returns in their respective models show no significant relationship with current firm performance. Moreover, \%IB displays no significant relationship with ROE or Stock Returns, thus rejecting Hypothesis 1 . This is in line with the corresponding FE and RE models, which suggest no evidence of a relationship or bias in the results or of an endogenous impact. The specification tests for the model including Stock Returns show that the Sargan test has a $p$-value of 0.000 . As such, the null hypothesis that the over-identifying restrictions are valid is rejected, which also means the model or instruments need to be reconsidered because they may exhibit misspecification or heteroscedasticity. By testing for second-order autocorrelation using robust standard errors, the null hypothesis of no autocorrelation is rejected. 
The AR(2) yields a $p$-value of 0.001 , thus providing further evidence of model misspecification. Therefore, the results indicate the rejection of Hypothesis 3 for the Stock Returns model.

The specification tests for the ROE model displayed a Sargan test $p$-value of 1 . Hence, the null hypothesis that the instruments are valid is not rejected. With regard to testing the $\operatorname{AR}(2)$ results with a $p$-value of 0.924 , the null hypothesis of no autocorrelation is not rejected, and thus, there is neither sufficient evidence to reject the model or instrument nor evidence of misspecification. However, it is worth highlighting that neither the lagged nor board composition variables are significantly related to current $R O E$, meaning it cannot be concluded whether endogeneity from past ROEs affects the board composition-performance relationship for the listed Saudi firms in the sample, although the dynamic panel GMM model appears to be correctly specified. Therefore, no evidence supporting Hypotheses 1 or 3 is found in the $R O E$ model. $^{2}$ The lack of evidence for a relationship also concurs with the corresponding RE and FE models.

Regarding the model using Tobin's $Q$, there is no significant evidence that board composition (\%IB) impacts Tobin's $Q$, and thus, no support for Hypothesis 1 . This is in line with the FE and RE models and also demonstrates there is no significant relationship with Tobin's $Q$. The lag of Tobin's $Q$ displays a significantly negative relationship ( -0.106$)$ with the current Tobin's $Q$ at the $10 \%$ significance level. In particular, the Sargan test resulted in a $p$-value of 0.000 , leading to rejection of the null hypothesis. The AR(2) yields a $p$-value of 0.088 , which means the null of no autocorrelation cannot be rejected. Therefore, it cannot be concluded whether endogeneity from past Tobin's $Q$ s affects the board composition-performance relationship, which means Hypothesis 3 cannot be supported, since the null hypothesis that the over-identifying restrictions are valid is rejected.

The second lag of $R O A$ in the dynamic model results in a positive relationship between board composition $(\% I B)$ and $R O A$, with a coefficient of 0.047 at the $5 \%$ significance level, thus supporting Hypothesis 1 . The lag of $R O A$ displays a negative relationship with current $R O A$, with a coefficient of -0.097 at the $5 \%$ significance level, which suggests that the poor historical performance of the listed Saudi firms in the sample has a negative impact on current performance, and the underlying relationship is dynamic when board independence and performance are simultaneously determined. This is in line with the theory that increases in the independence levels of boards lead to better firm monitoring and ultimately result in better firm decisions with more profitable outcomes.

When the endogenous lag variable is included in the GMM model, the GMM \%IB coefficient becomes significantly positive compared to the non-significant negative result $(-0.003)$ in the RE model and the positive result $(0.004)$ in the FE model. Therefore, isolating the impact of the poor past performance of Saudi firms from board composition leads to larger size and significance of the board composition-firm performance relationship. However, it cannot be ascertained whether the corresponding FE or RE models have a positive or negative bias on performance since neither display a significant relationship, which can suggest the presence of negative bias. The Sargan test resulted in a $p$-value of 0.123 , which means the null hypothesis that over-identifying restrictions are valid (i.e. the instruments are valid) cannot be rejected. This is because there is insufficient evidence to indicate that the model or instrument are misspecified or need to be reconsidered. Testing $\mathrm{AR}(2)$ resulted in a $p$-value of 0.234 , which does not cause the null hypothesis of no

\footnotetext{
2 Although it does not support my hypotheses, this could imply that the Saudi market is weak-form efficient and that one cannot make arbitrage returns by simply trading stocks based on board composition.
} 


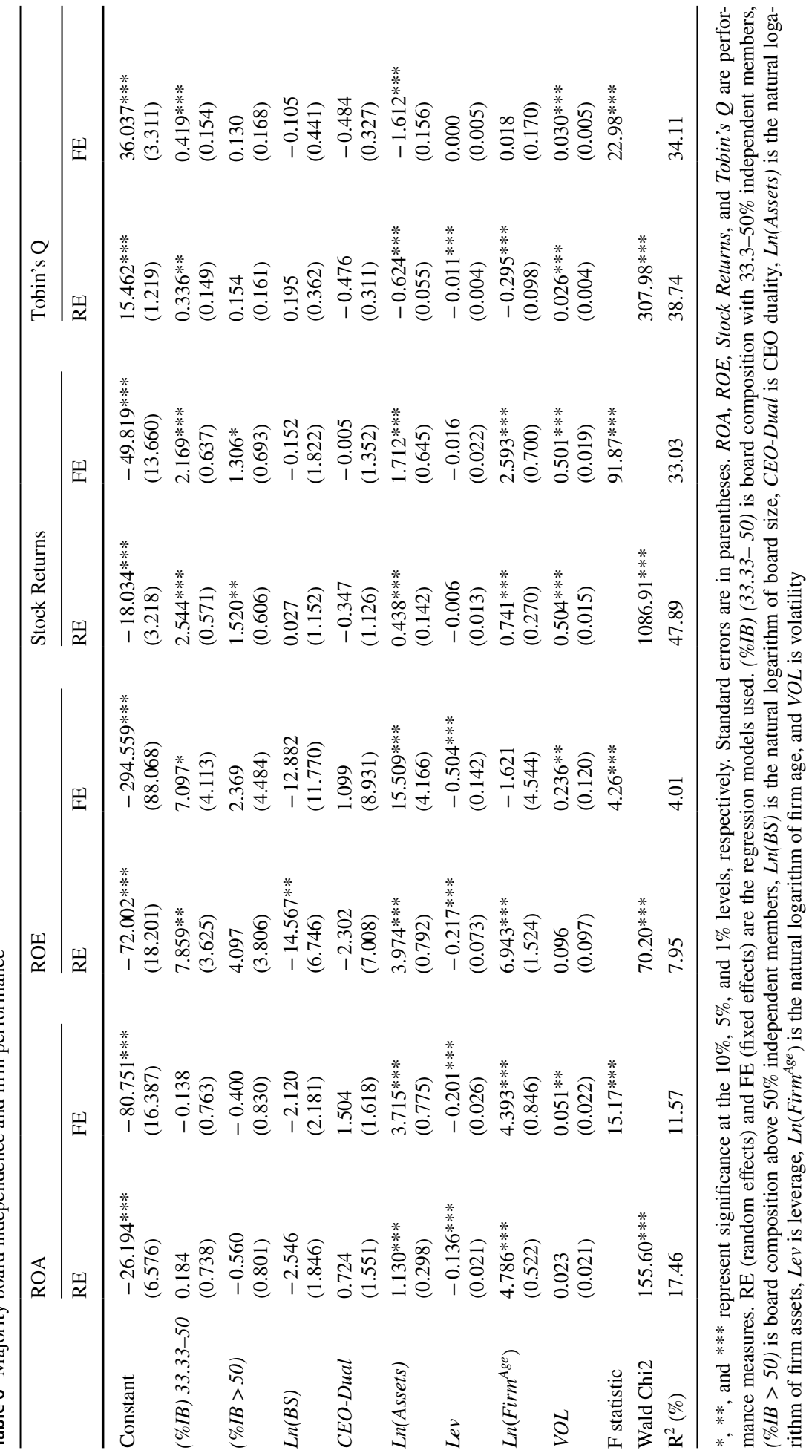


autocorrelation to be rejected, while also providing no evidence of model misspecification. In conclusion, past returns measured by $R O A$ affect current performance and determine board composition, as opposed to simply board composition affecting $R O A$. This not only supports Hypothesis 3 but also the results of Liu et al. (2015), who also found a significantly positive relationship in their dynamic GMM model for both ROA and ROE in China.

In Table 6, I generate two dummy board composition variables. The first is (\%IB) 33.33-50, which equals one if the percentage of independent directors on the board is more than $33.33 \%$ and less than or equal to $50 \%$; the variable is zero otherwise. The second is $(\% I B)>50$, which captures situations with a majority of independent directors, and equals one if they constitute more than $50 \%$; the variable is zero otherwise. RE and FE regressions are run for all four performance measures. The base group in the regressions represents listed Saudi firms with one-third or less board independence. It includes Saudi firms that ignored the corporate governance regulation stipulating that there must be either a minimum of two independent directors on a board or the board must be able to demonstrate that it exhibits at least one-third board independence, whichever is higher. The intercept term considers this and shows that all performance measures except Tobin's $Q$ have a significantly negative relationship with performance. Tobin's $Q$ displays a significantly positive relationship. The dummy variable (\%IB) $33.33-50$ has a significantly positive relationship with all performance measures except $R O A$. $(\% I B)>50$ shows a significantly positive relationship but only with Stock Returns. The ROE and Tobin's $Q$ models display positive but non-significant relationships, while the relationship with $R O A$ is negative and non-significant. The size of the coefficients of (\%IB) 33.33-50 are all greater than those of $(\% I B)>50$, suggesting that Saudi firms perform most effectively when board independence composition ranges between $33.33 \%$ and $50 \%$, while compositions above $50 \%$ have a negative impact on performance. This might be due to the lack of experienced insiders or to increased monitoring costs that deviate from the positive impact independent directors have on firm performance. ${ }^{3}$ It may also be that poor firm performance leads to inside directors being replaced with outside directors. Therefore, poorly performing firms are likely to have a higher than average outside director ratio (Hermalin and Weisbach 1988).

These findings support Hypothesis 1, the findings of Liu et al. (2015), and the views that independent directors in Saudi Arabia are not automatically selected and that Saudi firms have an economic incentive to select independent board members. This facilitates understanding how much of the board composition-performance relationship is due to the change in corporate governance regulations and how much of it is voluntary as opposed to mandatory, as well as the ideal composition for maximising performance. ${ }^{4}$

Dividing board composition into two dummy groups provides greater insight into the board composition-performance relationship than the RE and FE models in Table 5, whose results led to the rejection of Hypothesis 1. In sum, the results in Table 6 support Hypothesis 1.

Most studies in the literature on board composition tend to use ratios or proportions to characterise the extent of board independence. Many regulatory bodies also stipulate that there should be a minimum number of independent or outside directors on a board. In Saudi Arabia, the minimum number of independent directors is two or one-third of the

\footnotetext{
3 Table 8 presents the impact of monitoring cost on board independence.

4 Table 7 further investigates the critical mass of independent directors.
} 


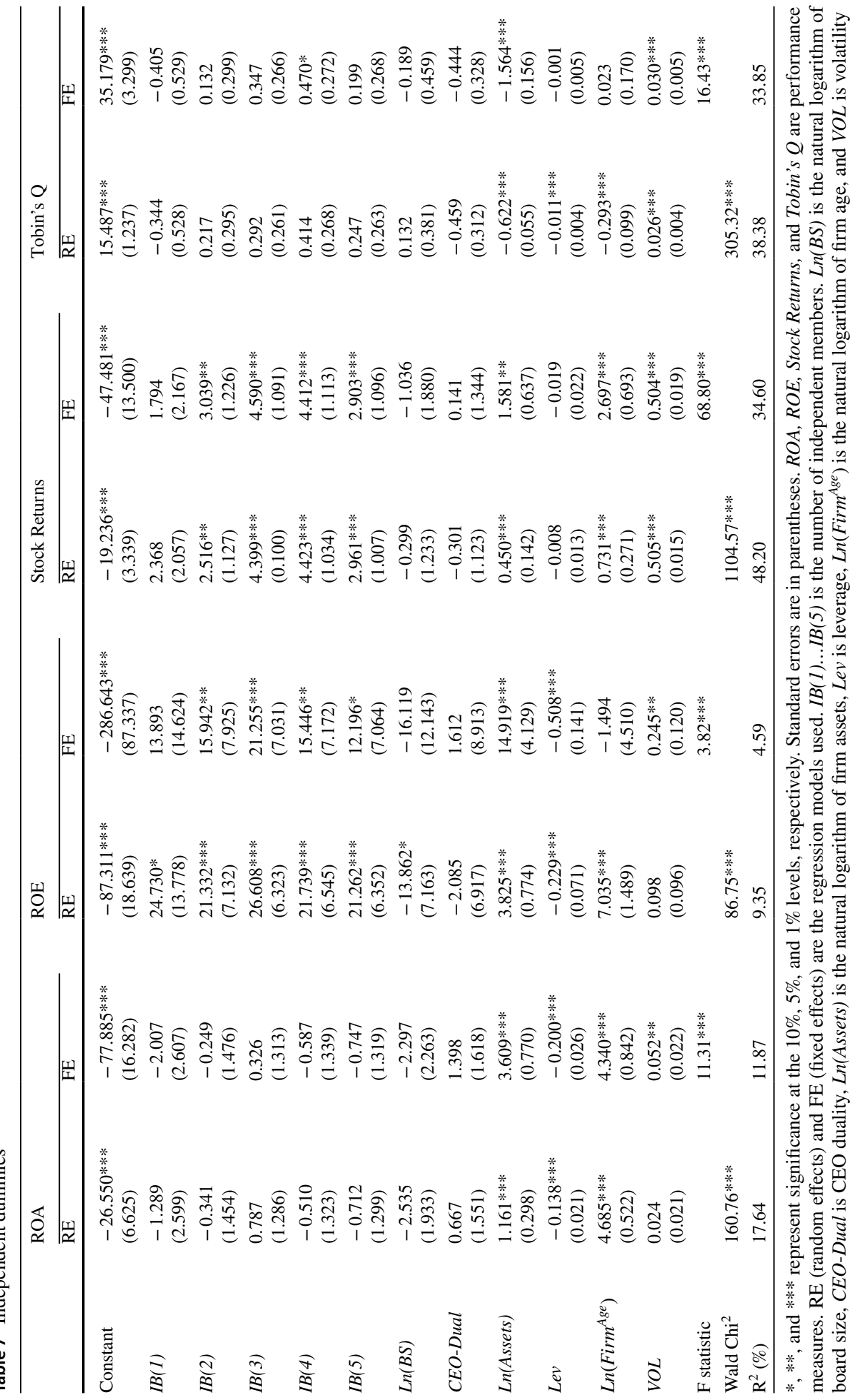


total number of board members, whichever is greater. Broome et al. (2011) argue that a critical mass of independent or outside directors is required for a board to be effective; otherwise, there is a tendency for boards not to have a meaningful effect on firm monitoring or decisions. I explore this variable in Table 7, that is, the critical number of independent directors for a board to be maximally effective, by re-estimating the models and replacing $\% I B$ with five binary dummy variables $I B(1), I B(2), I B(3), I B(4)$, and $I B(5$,) that indicate the presence of one, two, three, four, or five or more independent directors on a board. The results indicate no significant relationship between the number of independent directors and ROA and Tobin's $Q$, except $I B(4)$ under Tobin's $Q$ in the FE model, which was positive (0.470) and significant at the $10 \%$ level. The ROE and Stock Returns models display more significant impact from the number of independent directors for both the FE and RE models. $I B(1)$ has no significant impact on any of the performance measures, except $R O E$ under the RE model (24.730), where it is significant at the $10 \%$ level, suggesting that having one independent director on the board does not have a significant impact on the performance of Saudi firms and that lone independent directors are probably symbolic. This observation is consistent with the psychology literature, which points out that lone individuals are unlikely to express views opposing an otherwise unanimous group (Asch 1951 as cited in Liu et al. 2015). My findings also support those of Liu et al. (2015), who find that solo independent directors have no effect on the performance of Chinese firms. $I B(2)-I B(5)$ have significantly positive impacts on $R O E$ and Stock Returns. ROE is greatest when there are three independent directors on the board with coefficients of 26.608 and 21.255 for $\mathrm{RE}$ and FE, respectively, significant at the $1 \%$ level. For four or five or more independent directors, there is a decreasing impact on firm performance, although the impacts are still significant and positive. Stock Returns is highest for three to four independent directors, with similar coefficient estimates between 4.399 (RE) and 4.590 (FE), and significant at the $1 \%$ level. However, having five or more independent directors, although significant at the $1 \%$ level and positive, has smaller values: 2.961 (RE) and 2.903 (FE), thus supporting Hypothesis 1.

The mean (median) board size is eight (nine) directors. The mean (median) board composition is $49 \%$ (44\%), which suggests that Saudi firms might be appointing slightly more than the number of independent directors required to comply with corporate governance regulations. The results indicate Saudi firm performance is maximised by having three to four independent directors on the board and that Saudi firms with less than three independent members might improve their performance ( $R O E$ and Stock Returns) by increasing the number of independent directors to three or four. Again, my findings support those of Liu et al. (2015), who find a significantly positive relationship between independent directors and ROA and ROE in China. Liu et al. (2015) show that a critical mass of at least three independent directors had a significantly positive impact on performance, which is also the case in Saudi Arabia, although having even the minimum of two independent directors results in a significantly positive effect on $R O E$ and Stock Returns.

Table 8 shows the results of including an additional variable $\left(\% I B^{*} V O L\right)$, which measures monitoring costs in the original model (Table 5). Clearly, the board composition $(\% I B)$ coefficients indicate a significantly positive relationship with ROA (except in the RE model), ROE, and Stock Returns. This suggests that having a greater proportion of independent directors on the board leads to improvement in the performance of Saudi firms. Compared to the original model in Table 5, board composition $(\% I B)$ has a significantly positive relationship with performance once the interaction term $\% I B * V O L$, representing monitoring cost, is included in the model. This provides further evidence in support of Hypothesis 1, highlighting my initial conclusion based on the findings reported in Table 5 


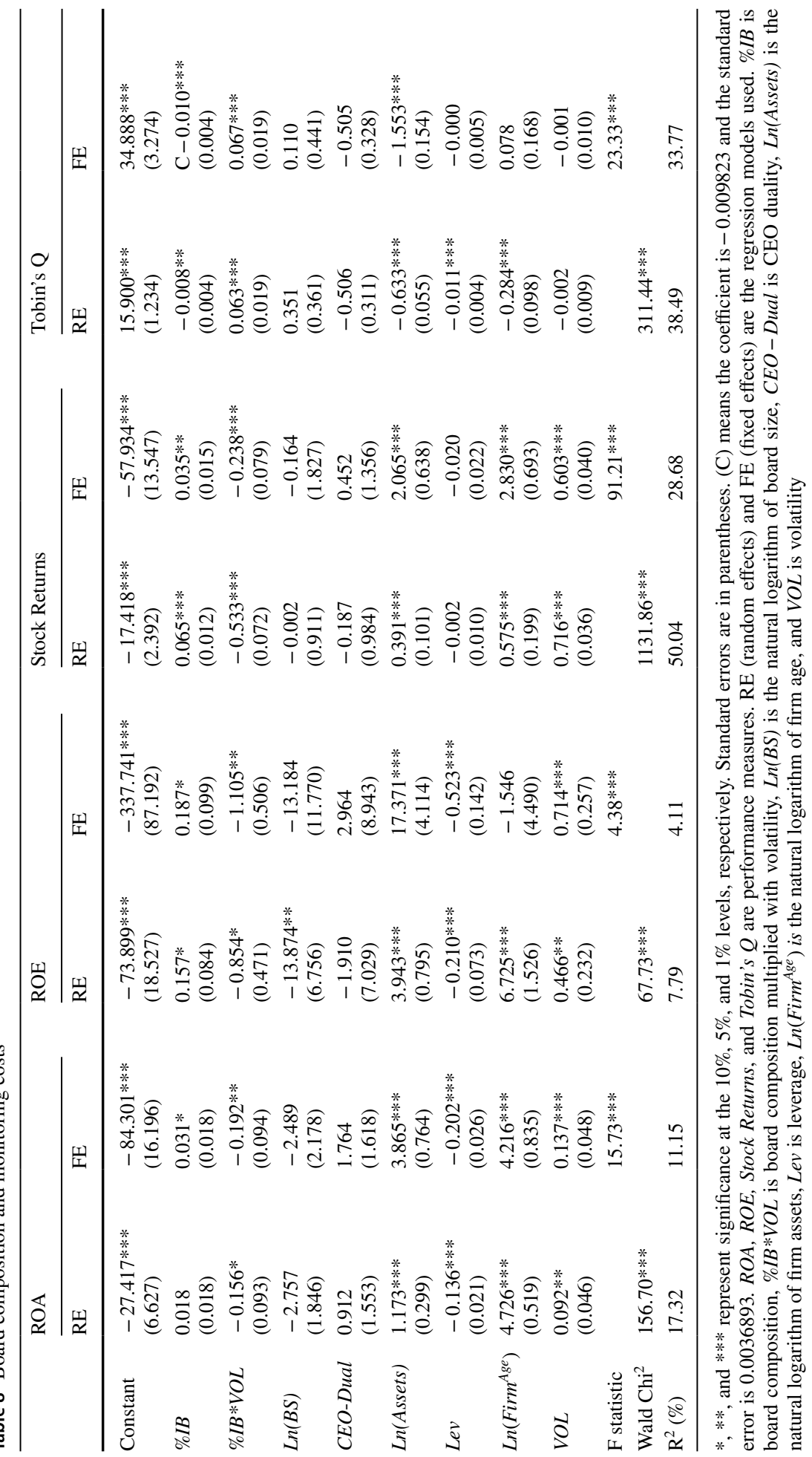


on rejecting Hypothesis 1 . The coefficient on $\% I B * V O L$ shows the impact of information asymmetry or monitoring cost on performance. I also find a significantly negative relationship between $\% I B^{*} V O L$ and $R O A, R O E$, and Stock Returns, which implies that the increasing monitoring costs faced by independent directors leads to a decrease in the performance of Saudi firms. In other words, the positive impact of independent directors on the performance of Saudi firms is reduced and thus, Hypothesis 4 is supported for all three performance models.

The Tobin's $Q$ results are opposite those of the rest of the models. For instance, $\% I B$ has a significantly negative relationship of -0.008 (RE) and $-0.010(\mathrm{FE})$ at the $5 \%$ and $1 \%$ levels, respectively. Additionally, both coefficients are close to 0 . The $\% I B * V O L$ estimates both display positive relationships, 0.063 (RE) and 0.067 (FE), significant at the $1 \%$ level. These are the smallest coefficients relative to all other performance measures. My findings are consistent with the literature, in that an increase in information asymmetry or monitoring costs leads to a decrease in the benefits associated with board independence. In fact, my results support those of Adams and Ferreira (2007) and Raheja (2005), who argue that the number of outside directors on a board decreases as monitoring costs increase. Further, Liu et al. (2015) and Duchin et al. (2010) find that firms with higher monitoring costs experience a reduction in the benefits that normally come from having more independent directors. My findings are in line with those of Li et al. (2015), who also demonstrate a significantly positive relationship between board independence and ROA in the Chinese market. Li et al. (2015) find that Tobin's Q has a significantly positive relationship with board independence, while I identify an almost 0 negative relationship.

Table 9 presents the results for the relationship between managerial pay and firm performance using RE, FE, dynamic GMM, and IV-2SLS estimations. In the RE models, $D$ $I N C$ has a positive relationship with $R O A, R O E$, and Tobin's $Q(2.18 \mathrm{e}-07,1.42 \mathrm{e}-06$, and $4.77 \mathrm{e}-08$, significant at the $10 \%, 5 \%$, and $5 \%$ levels, respectively) and a positive but nonsignificant relationship with Stock Returns. CEO-Ex-Pay only displays a significantly positive relationship with Tobin's $Q(4.33 \mathrm{e}-08)$ at the $1 \%$ level, while $C E O$-Shares has a significantly positive relationship with $R O A$ and $R O E$ (0.193 and 0.846, respectively, at the $5 \%$ level), but no significant relationship with Stock Returns or Tobin's $Q$. Therefore, Stock Returns is the only performance measure that has no significant relationship with any of the three pay variables. Based on the RE estimates, it can be concluded that increases in director incentives, top executive salary, or CEO share ownership lead to an increase in firm performance, thus supporting Hypothesis 5. Mehran (1995) maintains that incentive compensation impacts firm performance and efficiency; the positive relationship of $D$-INC with performance lends support to this conjecture. My results also support Fahlenbrach (2009), who shows that firms use compensation contracts to better align CEO and shareholder interests. Under FE estimation, $R O A$ and $R O E$ have no significant relationship with any of the three pay variables, thus failing to support Hypothesis 5; only Stock Returns is positively related to CEO-Ex-Pay (7.66e-08) at the $10 \%$ level. Tobin's $Q$ has a positive relationship with CEO-Ex-Pay and D-INC (3.92e-08 and 5.37e-08, at the $1 \%$ and $5 \%$ significance levels, respectively), therefore providing some evidence in support of Hypothesis 5 in the Stock Returns and Tobin's $Q$ models.

In summary, the key differences between the RE and FE models are that, in the latter, $D-I N C$ and CEO-Shares are no longer significantly related to ROA and ROE. CEO-Ex-Pay is now positively related to Stock Returns at the $10 \%$ level. Finally, all compensation variables under the FE and RE models display similar significant relationships with Tobin's $Q$. These results highlight that different empirical techniques and performance measures can lead to varying results. The RE models appear to be a better fit for the data, especially 
for accounting measures such as $R O A$ and $R O E$ but also for a market measure such as Tobin's $Q$. The FE method seems to be more appropriate for market measures such as Stock Returns and Tobin's $Q$. This is also evident in the $R^{2}$ values, which are higher in the RE than in the FE models.

Mehran (1995) also shows that CEO equity compensation is positively related to ROA and Tobin's Q, which agrees with the CEO-Shares estimated under the RE model but only for ROA. Mehran (1995) finds that top executives' cash compensation is negatively related to ROA and Tobin's Q; my results show a positive relationship between CEO-Ex-Pay and Tobin's $Q$ in the RE and FE models and a non-significant negative relationship between $C E O-E x-P a y$ and $R O A$ in both models. Conversely, Brick et al. (2006) use pooled and fixed effects regressions of CEO and director compensation on excess market returns in the US to identify a significantly negative relationship between compensation and firm performance, which contrasts with my results.

The GMM estimates in the $R O E$ model display no significant relationships with any of the managerial pay variables or between the lag variable and $R O E$. The Sargan test has a $p$-value of 0.998 . Therefore, I do not reject the null hypothesis that the over-identifying restrictions are valid. On testing $\operatorname{AR}(2)$, the $p$-value is 0.888 , meaning I do not reject the null of no autocorrelation. Further, I do not have evidence to suggest that the model or instrument suffers from misspecification. Therefore, I conclude there is no evidence of an endogenous relationship between managerial pay and past $R O E$ with current $R O E$, thus failing to support Hypothesis 5. This also could be due to the fact that considering endogeneity rather counters any bias in the data, which implies the possible efficiency of the Saudi Arabian market.

In the corresponding RE estimates, both CEO-Shares and D-INC have significantly positive relationships with $R O E$. However, under the GMM estimation, these relationships are no longer significant, and the magnitudes of the coefficients become smaller. The coefficient on $D-I N C$ even has a negative value under GMM, implying that the RE estimates may be positively biased. While the coefficients under the FE estimates are not significant, both $D$-INC and CEO-Ex-Pay change signs similar to the RE estimates. This further supports the existence of a positive bias when endogeneity is not considered. Only the signs of the CEO-Shares coefficients remain the same. Although it has a non-significant relationship with current $R O E$ in GMM, the lag variable is likely to have precipitated this change in the sign and significance of the coefficients. For example, CEO-Shares in the RE model may not actually have a significantly positive impact on current performance when the lag of past performance is considered as an explanatory variable for current performance. The GMM estimates in the ROA model display a significantly positive relationship with CEO-Shares (0.132) at the $1 \%$ level, while the lag of ROA displays a significantly negative relationship (-0.099) with current ROA at the 5\% level. Further, the Sargan test $p$-value of 0.031 results in rejecting the null hypothesis that the over-identifying restrictions are valid at a 5\% significance level, suggesting the model or instruments might need to be reconsidered. However, at the $10 \%$ level, I cannot reject the Sargan test null hypothesis. Moreover, testing AR(2) yields a $p$-value of 0.202 , which means I cannot reject the null of no autocorrelation. Compared to the corresponding RE estimates, the GMM estimates show that $C E O$-Shares is consistent in terms of sign and magnitude, although it decreases slightly, and is now highly significant at the $1 \%$ level. This confirms that CEO-Shares has a slightly reduced but more significantly positive impact on firm $R O A$ and that endogeneity is important. Additionally, in the RE model, $D-I N C$ displays a significantly positive relationship (2.18e-07) at the $10 \%$ level, but under the GMM it is no longer significant, and the sign becomes negative. When isolating the impact of past performance on current ROA 


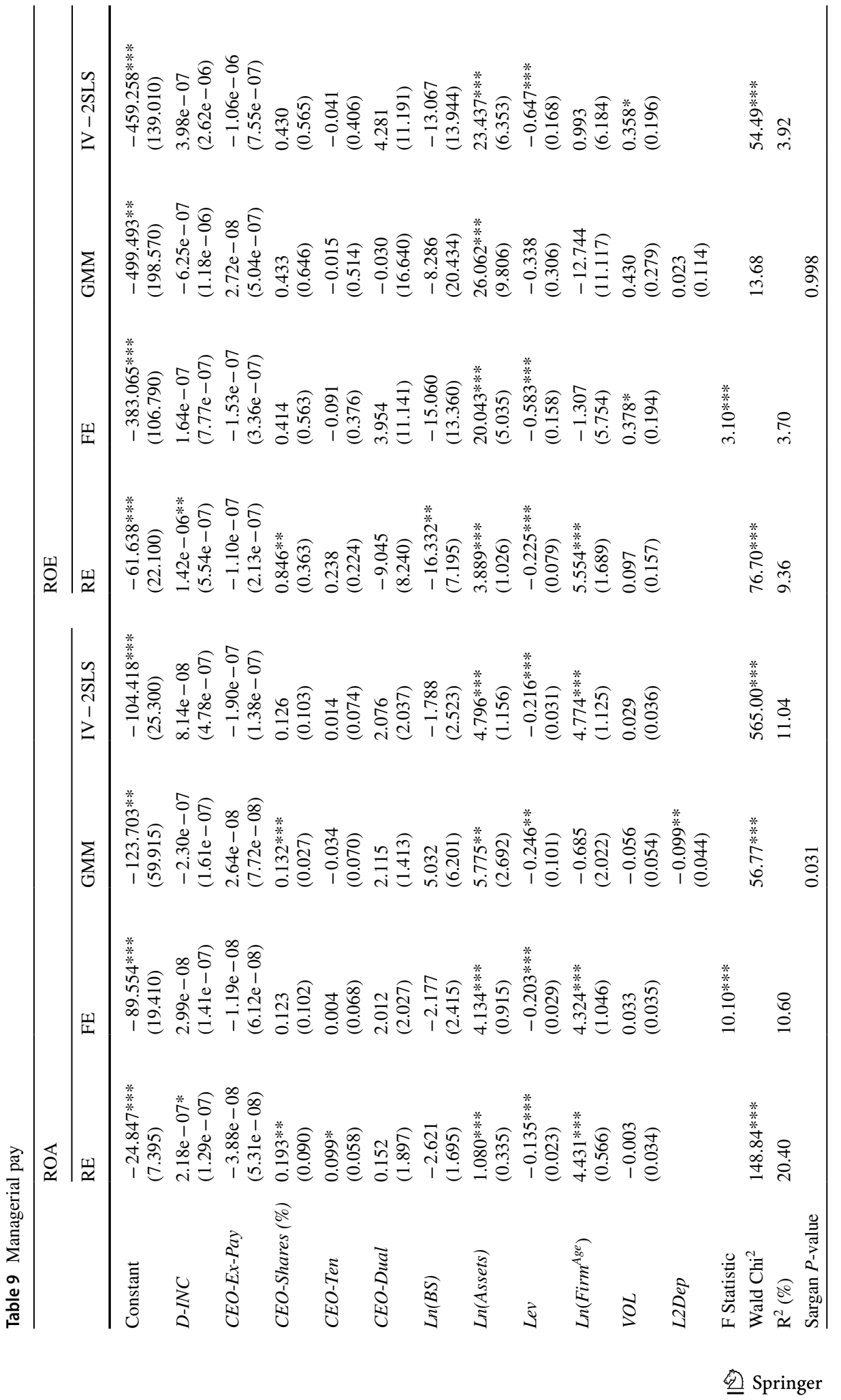




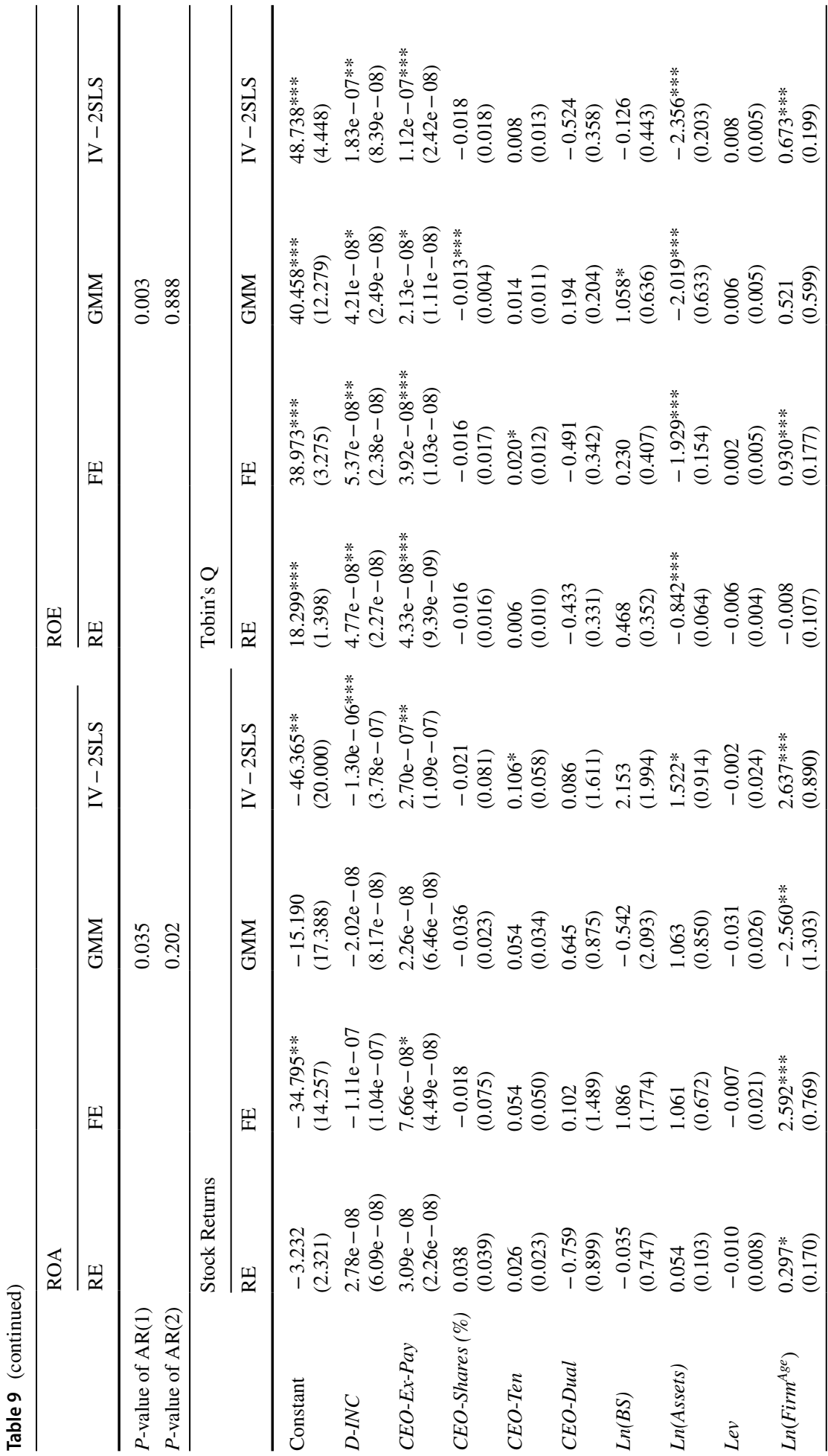




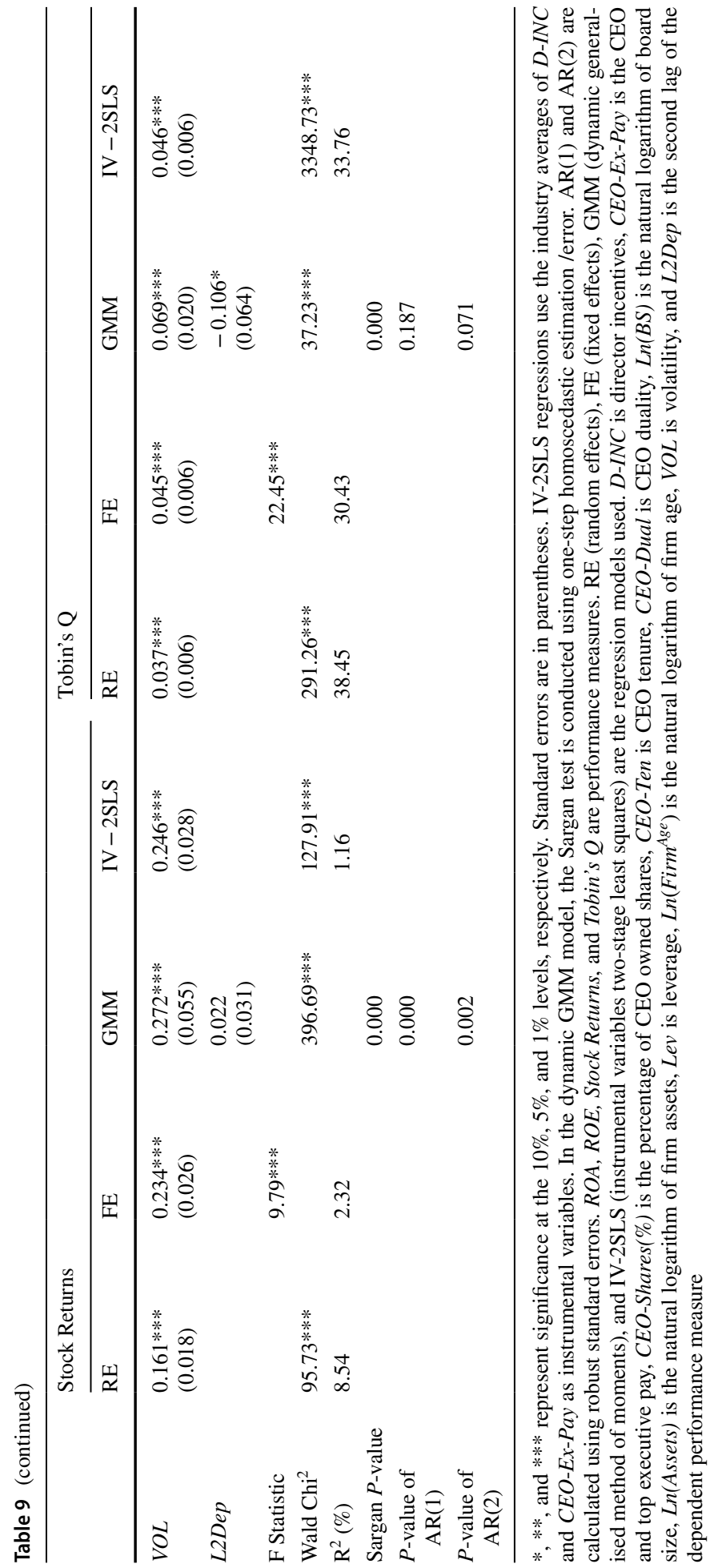


using its lag, the result is a significantly negative coefficient $(-0.099)$ at the $5 \%$ level, suggesting an endogenous relationship (i.e. poor past performance has a negative impact on current performance). This helps explain why the $D$-INC estimate is no longer significant and becomes negative under GMM compared to RE, highlighting that $D-I N C$ is positively biased in RE and thus rejecting Hypothesis 5.

Considering the non-significant CEO-Ex-Pay variables from the RE and FE models, their negative coefficients become positive and non-significant under GMM, which proves that including lags reduces the negative bias on the explanatory variables. Therefore, Hypothesis 5 is not supported in the GMM model. Theoretically, it makes more sense for $C E O-E x-P a y$ to have a positive relationship with performance, since increasing it should increase performance. In other words, reducing $C E O-E x$-Pay is unlikely to have a positive impact on performance. As such, when the impact is delineated from poor past performance using a lag, a better understanding of the relationship between managerial pay and firm performance is possible. In conclusion, models that do not consider endogeneity are likely to be biased.

Based on Arellano and Bond's (1988) DPD package estimation, Conyon and Nicolitsas (1998) focus on small- and medium-sized manufacturing firms in the UK and find a positive relationship between pay and performance. The relationship is stronger for smaller firms, and weaker relationships were identified for listed firms. The results reported in this paper support the findings of Conyon and Nicolitsas (1998) in terms of the expected signs of estimates, although they are not statistically significant. Brick et al. (2006) find director total compensation in the US to be negatively impacted by firm ROA, Tobin's Q, and stock returns in their pooled and FE regressions. My findings for the dynamic GMM support this finding, based on the positive bias in the RE estimates that is reduced once I consider the lag of $R O A$ as an explanatory variable.

In the Stock Returns model, no significant relationship emerges for any explanatory compensation variables with GMM estimates or for the lag variable with current Stock Returns. The Sargan test $p$-value of 0.000 rejects the null hypothesis that the over-identifying restrictions are valid. The AR(2) $p$-value of 0.002 also rejects the null hypothesis of no autocorrelation. Therefore, the model or instruments are misspecified and need to be reconsidered. Hence, the results do not support Hypothesis 5. Despite the rejection in the GMM specification tests, the FE CEO-Ex-Pay coefficient (7.66e-08) is no longer significant at the $10 \%$ level, and its magnitude decreases to 2.26e-08. This implies that including lagged Stock Returns corrects the possible positive bias in CEO-Ex-Pay under the FE estimation. This is similar to the GMM results in the ROA and ROE models for CEO-Ex-Pay, all of which have similar coefficients.

In the Tobin's $Q$ model, the GMM estimates reveal that $C E O$-Shares has a significantly negative relationship (-0.013) at the $1 \%$ level. D-INC and CEO-Ex-Pay have significantly positive relationships (4.21e-08 and $2.13 \mathrm{e}-08$, respectively) at the $10 \%$ level. The lag of Tobin's $Q$ displays a significantly negative relationship (-0.106) with the current Tobin's $Q$ at the $10 \%$ level, suggesting poor past performance has a significantly negative impact on current firm value. The Sargan test $p$-value of 0.000 rejects the null hypothesis that overidentifying restrictions are valid. Therefore, the model and instruments should be reconsidered. Furthermore, the AR(2) $p$-value of 0.071 fails to reject the null hypothesis of no autocorrelation at the $5 \%$ significance level; however, at the $10 \%$ level, $H_{0}$ is rejected. Thus, caution is required when drawing such inferences, since the results do not support Hypothesis 5 despite the significance of the explanatory variables.

In comparison with the FE and RE models, $C E O$-Shares now has a highly significant and negative coefficient, but it is similar in magnitude to the previous ones. The negative 
relationship with Tobin's $Q$ could be the result of a non-linear relationship between managerial ownership and firm value, as per the literature (Morck et al. 1988). Comparatively, the CEO-Ex-Pay and D-INC estimates are positive and significant at the $1 \%$ and $5 \%$ levels, respectively. Under GMM, both the CEO-Ex-Pay and D-INC coefficients decrease to $2.13 \mathrm{e}-$ 08 and 4.21e-08, respectively and are significant only at the $10 \%$ level, further suggesting that the FE and RE models suffer from positive bias. The IV-2SLS results with Tobin's $Q$ as the performance measure reveal that the industry average instrumental variables have a significantly positive relationship with $D$-INC (1.83e-07 at 5\% level) and CEO-Ex-Pay (1.12e-07 at the $1 \%$ level), meaning that the industry average pay has an indirect impact on firm performance. This suggests firm value increases when CEOs and other executives are paid more, as well as provided with increased director incentives, thus supporting Hypothesis 5. Compared to the FE estimate, there is an increase in the coefficient magnitude for CEO-Ex-Pay, which suggests the FE and RE estimates are biased. The Tobin's $Q$ IV-2SLS results support the GMM estimates, although the Tobin's $Q$ GMM model was misspecified.

For Stock Returns, IV-2SLS shows the instrumental variables have a significantly negative impact on the relationship with $D-I N C(-1.30 \mathrm{e}-06$ at the $1 \%$ level) and a significantly positive relationship with $C E O-E x$-Pay (2.70e-07 at the $5 \%$ level), thereby providing evidence supporting Hypothesis 5. Comparing the $D$-INC estimations for the RE and FE models with those of the IV-2SLS points us towards a positive bias in RE and FE estimates, although the RE and FE estimates were not significant. However, comparing the $C E O$ Ex-Pay estimate in IV-2SLS with the corresponding non-significant RE estimate and the significantly positive FE estimate (7.66e-08 at the $10 \%$ level) shows an increase in the coefficient magnitude and significance level, displaying evidence of a negative bias in the RE and FE estimates. In other words, bias exists if endogeneity is not considered.

For $R O A$ and $R O E$, the IV-2SLS regressions show instrumental variables have no significant impact on the relationships with any of the endogenous pay variables. Therefore, the findings reject Hypothesis 5. Compared to the RE estimates in both the ROA and ROE models, which display significantly positive relationships for $D$-INC and CEO-Shares with firm performance, these are no longer significant under IV-2SLS, although the sign of the coefficients is the same. This suggests that the RE model might suffer from positive bias. My findings support those of Lahlou and Navatte (2017), who use the IV-2SLS model to study median equity-based pay as an instrument and find it has a positive impact on firm stock returns around the announcement date of an acquisition bid. This suggests that equity-based compensation is an incentive for directors to make decisions that are in shareholders' interests. My results also lend support to Chen et al. (2010), who identify a positive impact on Chinese executives' pay from global pay benchmarks driven by foreign investments. The authors argue that the executive pay levels were rather influenced by global peer levels than through their relationship with firm performance. My findings for the IV-2SLS approach confirm and extend this idea further by using Saudi industry average pay variables as instruments to explore the impact on Saudi firm performance.

My findings from both the IV-2SLS and GMM models regarding the endogenous relationship between executive pay and performance support the results of Chen et al. (2010), who find that CEO ownership and duality contribute positively to executive compensation. This implies executive compensation is endogenously determined. Furthermore, the authors find that the performance measures ROE and growth opportunity (market-to-bookvalue of assets) have a significantly positive impact on executive pay, which is also highlighted by Conyon and He (2011). Hence, I have sufficient evidence from the IV-2SLS regressions to suggest that the Saudi industry averages of D-INC and CEO-Ex-Pay affect 
the endogenous explanatory variables measuring individual firm pay and will ultimately impact the performance of listed Saudi firms.

Although the Saudi riyal is pegged to the USD, I further investigate whether this impacts the results of managerial pay on firm performance. "Appendix" 1 shows that utilising USD for all monetary values still provides the same outcome regarding coefficient signs and significance. A small difference is shown in one of the constant variables, where the significance level dropped from 1 to $5 \%$ under RE estimates in the ROE model. Thus, the USD or riyal difference does not significantly impact the findings.

\subsection{Support results for government firms}

To further investigate the board composition-performance and managerial pay-performance relationship in government firms, I study 28 government firms between 2008 and 2014, providing 168 observations to investigate. I do not use government ownership variables before 2008 because the disclosure and transparency rule in the Saudi corporate governance code only began in 2008. Following Berle and Means (1932) and Al-Faryan and Dockery (2017) to classify firms as government owned, I use the $20 \%$ equity ownership stake as a minimum level that has the sufficient equity to render control and classify them as such.

The DID method requires firms to exist in the sample before the exogenous shock in regulation by the end of 2008 . Therefore, I excluded 5 of the 28 government firms only for the DID analysis.

Table 10 presents the analysis results of board composition and performance of Saudi government firms. Similar to Table 5, I find that when simply using RE and FE models, there are no significant relationships between board composition and firm performance, thus not supporting Hypothesis 1 . However, when I consider endogeneity issues similar to Table 5, the results become more interesting and informative. The DID approach in performance measures of Stock Returns and Tobin's $Q$ yield significant positive performance differences of 6.048 and 0.259 , respectively, at the $1 \%$ and 5\% significance level for Saudi government firms that implemented post-2009 corporate governance regulations stipulating that at least two or one-third of directors must be independent, thus supporting Hypothesis 2. This concurs with Table 5 for all Saudi listed firms, with the difference being in the Tobin's $Q$ model where it is significant at $1 \%$. The DID results for $R O A$ and $R O E$ models here display no significant relation. Previously, in Table 5, ROA had a significant negative relation. This can suggest that government firms choose to obey the corporate governance regulation requirements, preferring to avoid paying any fines.

The GMM results from the ROA model shows a positive relationship between board composition $(\% I B)$ and $R O A$, with a coefficient of 0.047 at the $10 \%$ significance level, thus supporting Hypothesis 1 . The lag of $R O A$ displays a negative relationship with current $R O A$, with a coefficient of -0.430 at the $1 \%$ significance level, which suggests a dynamic relationship exists when board independence and firm performance are simultaneously determined. Hence, poor past performance of Saudi government firms has a negative impact on current $R O A$ performance, and not simply board composition effecting ROA. This is similar to the results of the corresponding model in Table 5. However, the Sargan test $p$-value of 0.001 rejects the null hypothesis that the over-identifying restrictions are valid at a $1 \%$ significance level, suggesting the model or instruments might need to be reconsidered. Testing AR(2) yields a $p$-value of 0.504 , which means the null hypothesis of no autocorrelation is not rejected. This might be due to the smaller sample size 
of government firms in this study. Therefore, caution is required when drawing conclusions. GMM estimation in the $R O E$ model results in no significant evidence to show that board composition $(\% I B)$ impacts $R O E$, and thus does not support Hypothesis 1 . The lag of $R O E$ (L2Dep) shows a significant negative relationship (-0.328) with current $R O E$ at the $1 \%$ significance level. Showing evidence that past performance has a negative impact on current performance. However, the Sargan test resulted in a $p$-value of 0.002 , thus rejecting the null hypothesis. Regarding testing the $\mathrm{AR}(2)$ results with a $p$-value of 0.489 , the null hypothesis of no autocorrelation cannot be rejected. Therefore, it cannot be concluded whether endogeneity from past $R O E$ affects the board composition-performance relationship, which means Hypothesis 3 is not supported, since the null hypothesis is rejected (that the over-identifying restrictions are valid). The results of the GMM estimation in Stock Returns and Tobin's $Q$ models are not significant and therefore do not support Hypothesis 1 nor Hypothesis 3.

In summary, Saudi government firms provided evidence that post the corporate governance code and 2009 exogenous shock on board regulation, there was a significant positive relationship between board composition and firm performance, especially when performance is measured using ROA, Stock Return, and Tobin's $Q$. These findings are robust to endogeneity issues as FE and RE models displayed no significant relationships until endogeneity was considered using dynamic GMM estimation. These findings also show that the results can be sensitive to performance measures and the methodology employed to model studies.

To further empirically investigate that managerial pay-for-performance does matter and that the Saudi government does not simply influence Saudi firms, I conduct further analysis into government firms in Saudi Arabia. Table 11 displays the results of the relationship between managerial pay and performance in Saudi government firms. ${ }^{5}$

The results show CEO-Ex-Pay significantly impacts positively on both $R O A$ and $R O E$ models, except under the IV-2SLS model in $R O E$ where the coefficient is positive but not significant. Under all Stock Returns and Tobin's $Q$ models, CEO-Ex-Pay did not result in any significant relationship with performance. Based on the CEO-Ex-Pay variable an increase in pay should yield greater performance in Saudi Arabia when looking at accounting measures. This further demonstrates that pay-for-performance matters in Saudi Arabia, suggesting that firms are competitive and not simply controlled by the Saudi government. These findings interestingly corroborate with Table 9, the only difference being in the full sample of Table 9 market performance measures (i.e. Stock Returns) and Tobin's $Q$ were generally significant and positive and not accounting measures (i.e. $R O A$ or $R O E$ ) as displayed here in Table 11. I deduce that not only pay-for-performance matters in Saudi Arabia, but when extracting focus on government firms, are more interested and focussed on accounting measures rather than market measures. This evidently supports Hypothesis 5. Moreover, it further supports Al-Faryan and Dockery's (2017) finding that accounting measures are more influential in determining ownership structure.

The $D$-INC variable in the Stock Returns models displays a significant and negative coefficient in RE (-7.65e-07), FE (-1.41e-06), and GMM (-1.26e-06) models, significant at the $10 \%, 5 \%$, and $1 \%$, respectively. In Tobin's $Q$ models it was only under the GMM model that the $D-I N C$ variable has a significant negative coefficient $(-1.30 \mathrm{e}-07)$, at the $1 \%$ level. This fails to support Hypothesis 5, for a positive impact on performance. Comparing

\footnotetext{
5 Note: "Appendix" 2 displays the correlation matrix for the endogenous variable used in the IV-2LS analysis for government firms.
} 


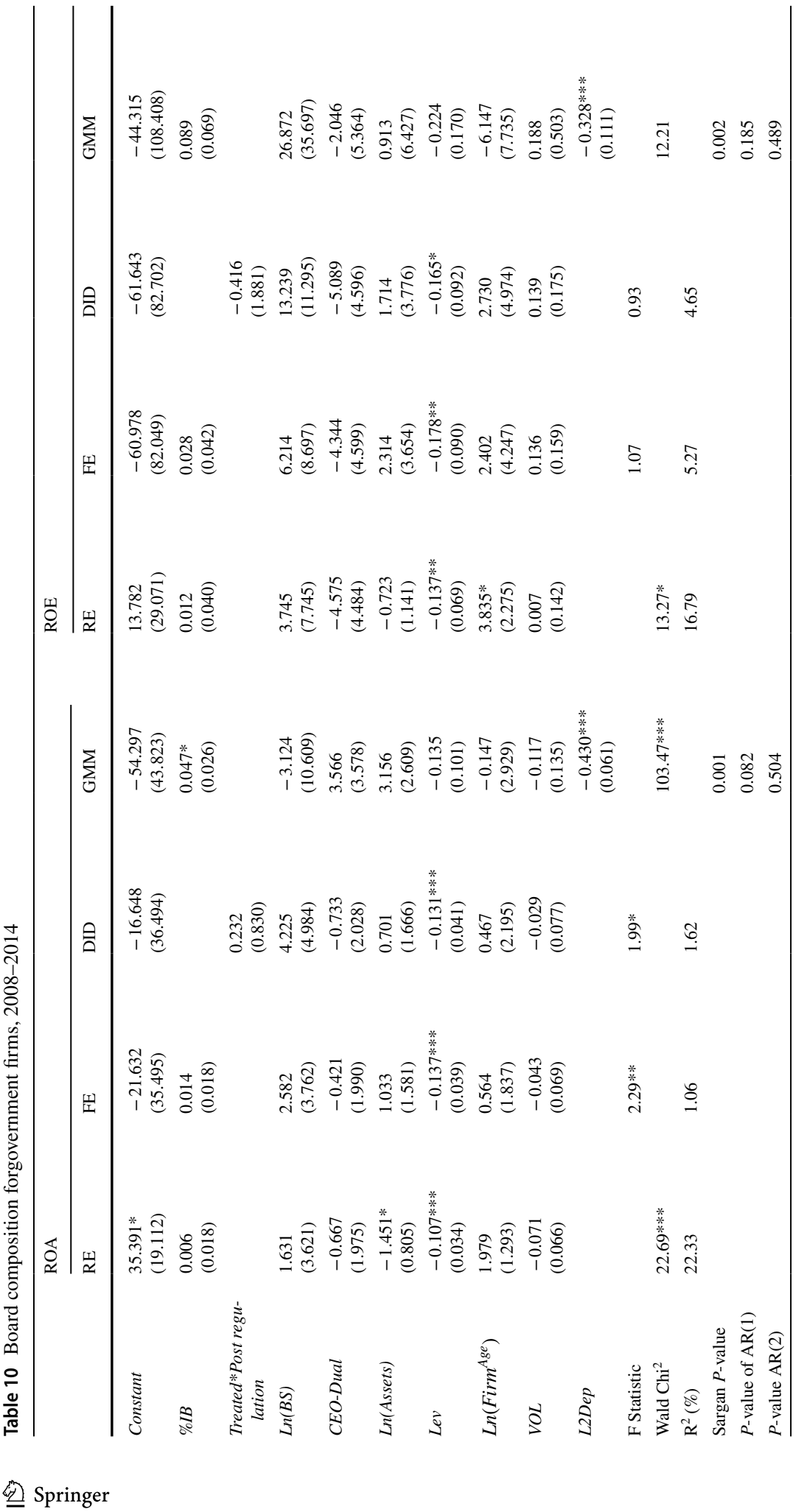




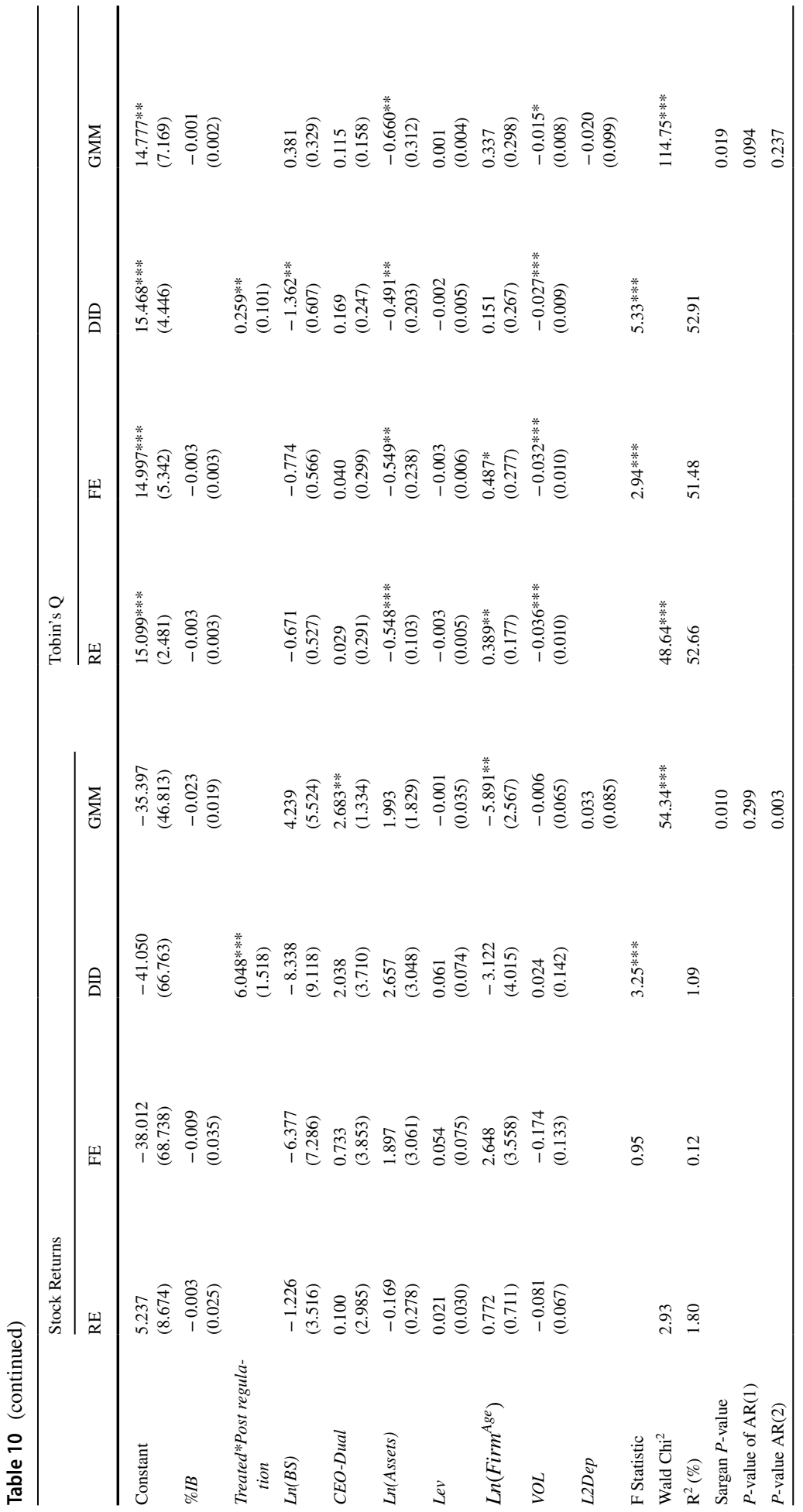

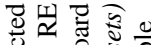
它

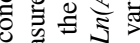

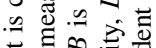
Q

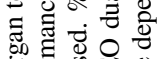
窟 \& 0.4

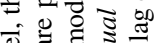
의웡

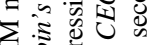
$\sum_{0} \frac{0}{0} 0$ 을

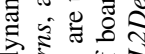

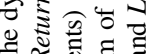

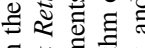
$\Xi \breve{~}$

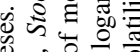

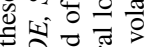
证舟

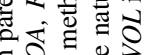
$\exists$ 象正 औ s -

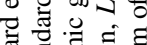

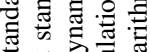

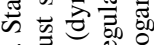

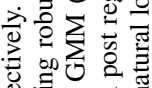

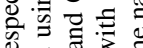
궁 i 0.0 흘 흄

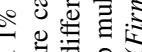
สิ ฮิ

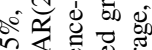
$\therefore-0$ 跑

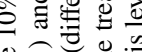

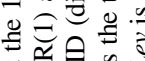

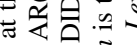

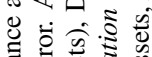
压吉 要 点

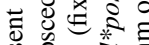

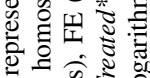
웡ㅊㅇ

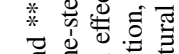
矛

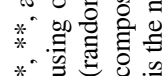


this to the full sample of firms in Table 9, the $D-I N C$ variable displays positive significant coefficients in ROA and ROE under RE models, in Tobin's $Q$ all models display a significant positive coefficient, and in the Stock Returns models only the IV-2SLS model displays a significant negative coefficient. The variation in the results between Tables 9 and 11 suggests that when incentives for the board of directors in government firms decreases marketbased measure that capture the positive sentiment placed by investors in the firm's value. It also implies that government firms face greater accountability through reduced director incentives if performance is poor. This, in turn, is reassuring for smaller shareholders in government firms. Furthermore, some members of government firms on the board are from ministries of governmental institutions, bodies, and authority and thus do not receive as much incentive rewards for performance as such is their duty in the first place. This further supports that pay-for-performance is relevant even in government firms.

The CEO-Shares variable is only significant negative coefficient $(-68.648)$ with Stock Returns in the GMM model, failing to support Hypothesis 5. This contrasts with the finding in Table 9 that positive and significant coefficients in the ROA and $R O E$ models result under RE methods. Thus, showing that government firms do not use CEO-Shares as an incentivising mechanism as other listed firms would. Government firms are more likely to use $C E O-E x$-Pay as the key mechanism for managerial incentives as the corresponding variable is positive and significant in government firms and not in the full sample. This potentially implies that government firms eliminate entrenchment issues and that pay-forperformance does matter and is more important than other incentives; that management are employed to fulfil a role. This lends further evidence that accounting measures in Saudi Arabia are more important in evaluating government firms when it comes to deciding managerial compensation such as $C E O-E x$-Pay and CEO-Shares.

The dynamic GMM methods under $R O A$ and $R O E$ models show a significant and negative lag variable of -0.356 and -0.234 at the $1 \%$ and $5 \%$ significance levels, respectively, suggesting poor historical performance has a negative impact on current performance. The Sargan test for all GMM models has been rejected and therefore, caution is required when drawing conclusions. However, the GMM results generally concur with the RE, $F E$, and IV-2SLS results.

A further implication of the finding that pay influences performance is that firms are competitive and not simply controlled by the Saudi government. This refutes the findings of studies in China (Jiang et al. 2020; Gu et al. 2010; He et al. 2016) that government representation, which exists in most firms (Zhao 2020), is likely to jeopardise the integrity of board independence and may even adversely affect shareholder wealth maximisation. In Saudi Arabia, government firms are subject to the same corporate governance laws as public firms. There have in fact been instances of fines imposed on government firms, such as the fine imposed upon the Saudi Real Estate Co. (65\% government owned) in May 2019 (CMA 2019).

\section{Conclusions}

In this paper, I have presented empirical evidence on the issue of board composition in relation to firm performance in the context of exogenous shocks induced by changing regulations. Building on the criticisms in the literature, I considered endogeneity in the statistical approach and discovered that the board composition-performance relationship is an endogenous one, while RE and FE displayed no significant relationship. The findings 


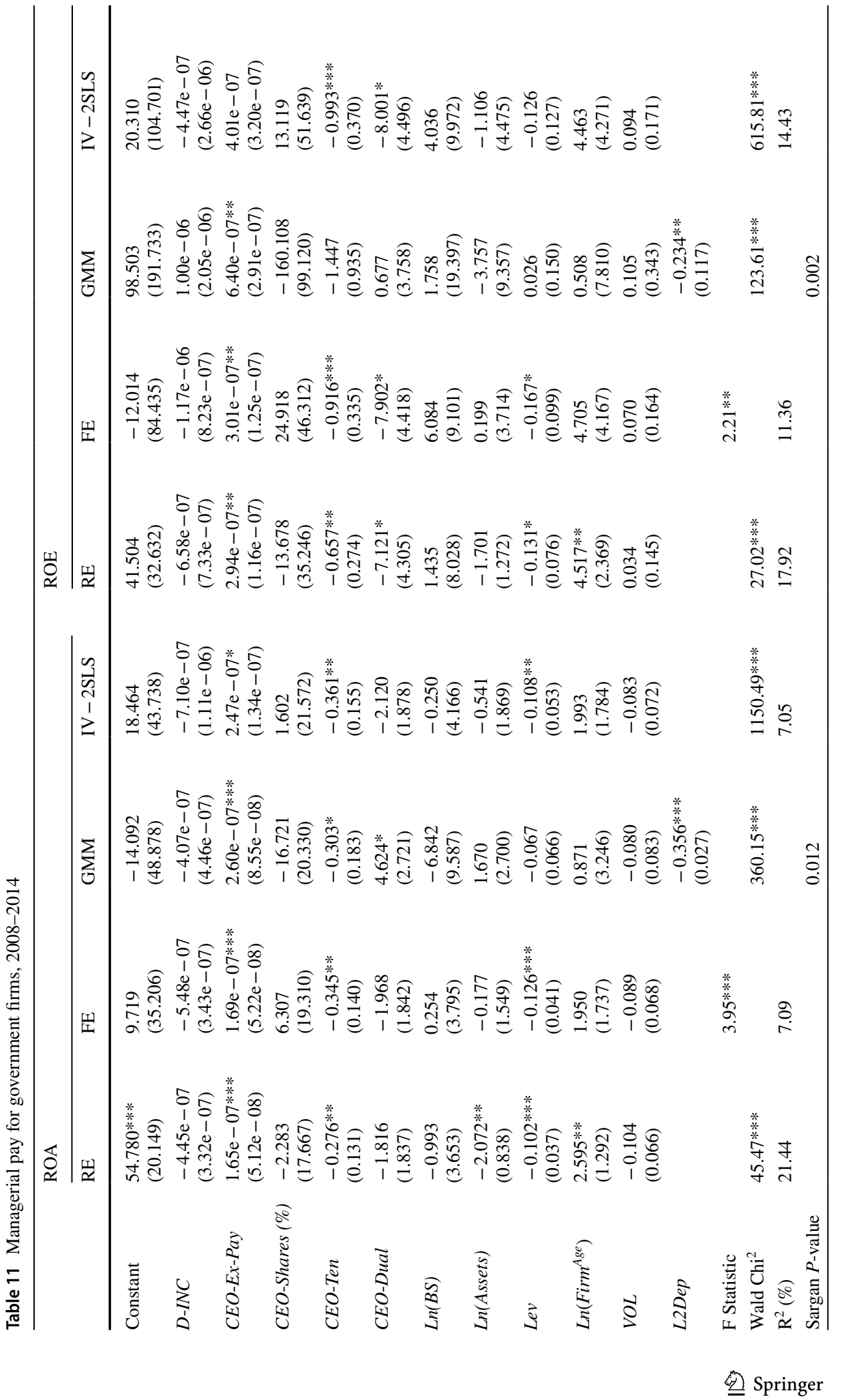




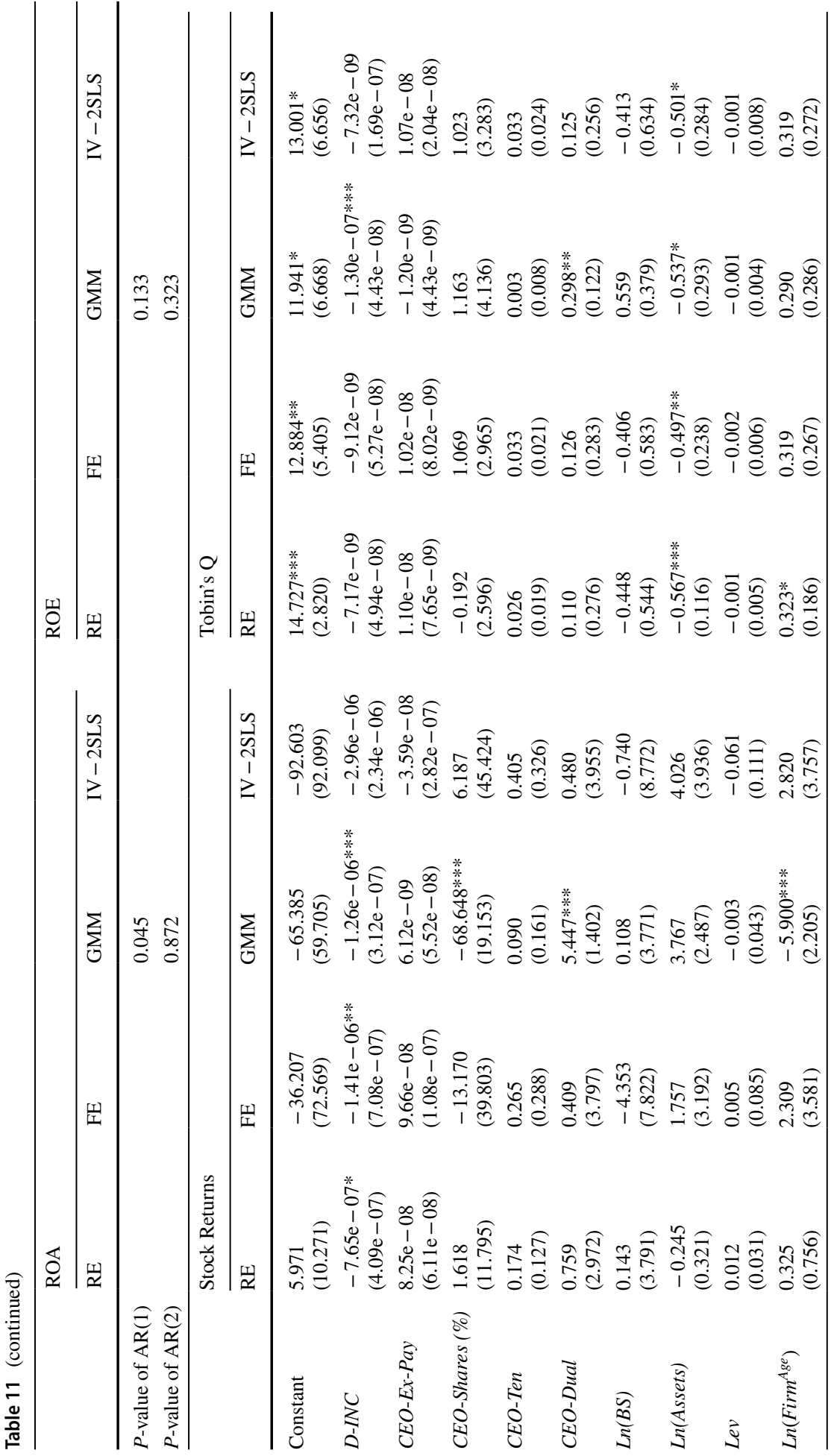




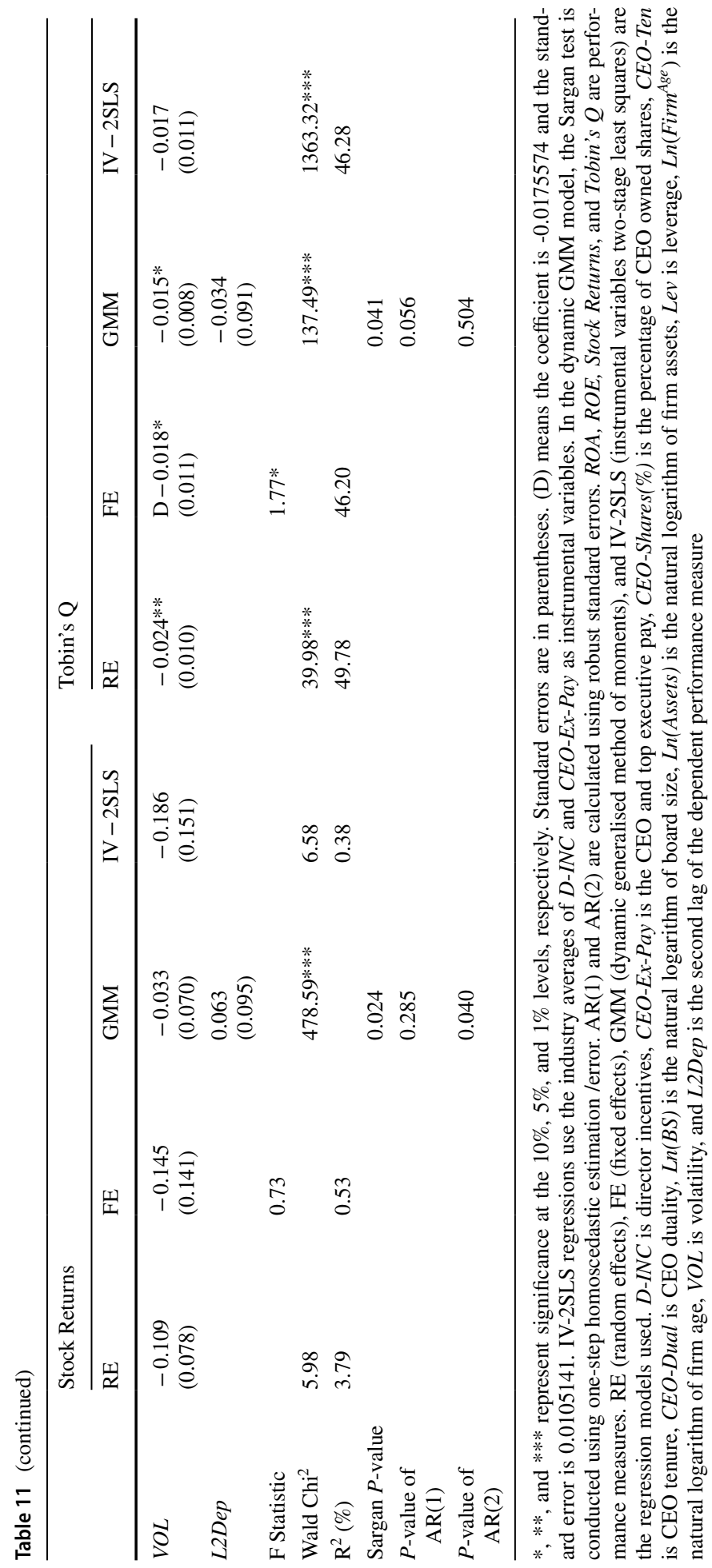


also highlight an endogenous relationship when using dynamic GMM estimation. Further, board composition was found to have a positive relationship with $R O A$, while poor past firm performance had a negative impact on current firm performance. A positive relationship was also found in relation to board composition and Stock Returns and Tobin's $Q$, using the DID approach for Saudi firms that chose to act in accordance with the regulations, as opposed to firms that chose to disregard them. In relation to board independence, further tests found that boards with $33.33-50 \%$ independent directors show a greater positive and significant relationship with firm performance than those with more than $50 \%$ independent directors. The evidence also indicates that firm performance was negatively affected under information asymmetry and increasing monitoring costs for independent directors, which also reduced the positive impact that independent directors had on the performance of Saudi firms.

I also focussed on the critical mass (i.e. the smallest number) of independent directors and found firm performance was at its best for three or four independent directors on a Saudi firm's board. However, a positive relationship remained when the number increased to five or more independent directors, although firm performance declined. The performance relationship with two independent directors was not as strong as that for three or four independent board members. Generally, firms with only one independent director did not manifest a significant relationship with performance.

The study also examined the relationship between managerial pay and firm performance using three pay variables: director incentives, CEO and top executive pay, and CEO share ownership, and found evidence of a significantly positive relationship between the three pay variables and firm performance using the RE and FE statistical approaches. A further investigation into the relationship including endogeneity and using dynamic GMM and IV2SLS methodologies indicated a positive relationship with performance. It also indicated that bias exists in the RE and FE models if endogeneity is not considered.

Finally, this study also shows that pay-for-performance in Saudi Arabia matters and firms are not simply controlled by the government as might be the case in certain countries, such as China. Further analysis of government firms support this, by showing that board independence displays a positive relationship to firm performance in Saudi Arabia.

The results from the various methodologies and techniques have shown that utilising appropriate methods and procedures and focussing on the different variables selected, such as the performance measure, are vital in determining the outcome. Thus, while following existing literature in investigating and understanding markets such as those in Saudi Arabia, it is also crucial to select the appropriate techniques and adjust models to better capture the structural differences, both explicit and implicit, of a developing market such as Saudi Arabia, even though it may prima facie appear to be similar to western markets following the Organisation for Economic Co-operation and Development (OECD) governance procedures, International Financial Reporting Standards (IFRS), and other best practices. This study has shown that a one-size-fits-all approach would not be appropriate and that a more practical and pragmatic approach is required to further understand the Saudi market's functioning.

Despite the varying results, this paper provides valuable insights for Saudi policy makers to better understand the impacts of the recent measures implemented in Saudi Arabia. The findings can also enable Saudi policy makers to develop corporate governance measures that are more in tune with current practices and the corporate environment in Saudi Arabia. This means that Saudi Arabia can become an example for other Arab countries seeking to implement stronger corporate governance practices, as the regulation of independent directors on Saudi boards can be viewed as a success. It highlights that 
establishing solid corporate governance regulations and enforcing them, as well as having the right management incentives to align interests, can result in improved firm performance. Finally, the managers of Saudi firms can benefit from this study's results when evaluating market-wide performance in relation to corporate governance regulations. Thus, the study underscores the importance of good corporate governance mechanisms and the benefits such mechanisms can have on the firm's performance, as well as on how the firm is understood from the outside. Thus, it portrays the positive perception of investors and shareholders with regard to corporate governance regulations applied in listed firms. This positive perception will also induce investment in Saudi stocks by domestic investors, in addition to foreign and institutional investors looking to diversify their portfolios since Saudi Arabia's recent opening of its economy to foreign investors and the results show that firms are not simply controlled by the government. This study's findings suggest that individual firm managers must proactively pursue effective corporate governance practices that will ultimately have a positive impact on firm value.

\subsection{Study limitations}

While an in-depth analysis of corporate governance was performed in this study, the analysis is not without limitations. A major limitation is the lack of available data for the Saudi market, which proved challenging to obtain. As a result, the data had to be sourced from the CMA and Mubasher, resulting in a unique database not previously available. Additionally, the amount of data available was limited, and time and financial restrictions were two further limitations that exacerbated the data issue. Despite the limited data and resources, I believe the study contributes towards filling the gap in the literature on corporate governance in Saudi Arabia, and should be of benefit to managers, investors, market practitioners, and regulators. Another limitation of this study is the existence of other endogenous factors that influence the underlying relationships and are difficult to model, an issue further exacerbated by the lack of readily available Saudi data. However, this study did produce significant results that were robust to endogeneity issues.

\subsection{Directions for future research}

Since the board of directors performs multiple functions that concern, for example, financial policy, replacement of managers, and preparation of strategic plans, as well as other actions that affect the performance of listed Saudi firms, it would be interesting to study the stock market reaction to the appointment of boards for listed Saudi firms with the purpose of determining whether there are abnormal reactions in the Saudi stock market to such announcements and, in turn, whether abnormal returns differ with respect to the characteristics of new additions to Saudi boards. 


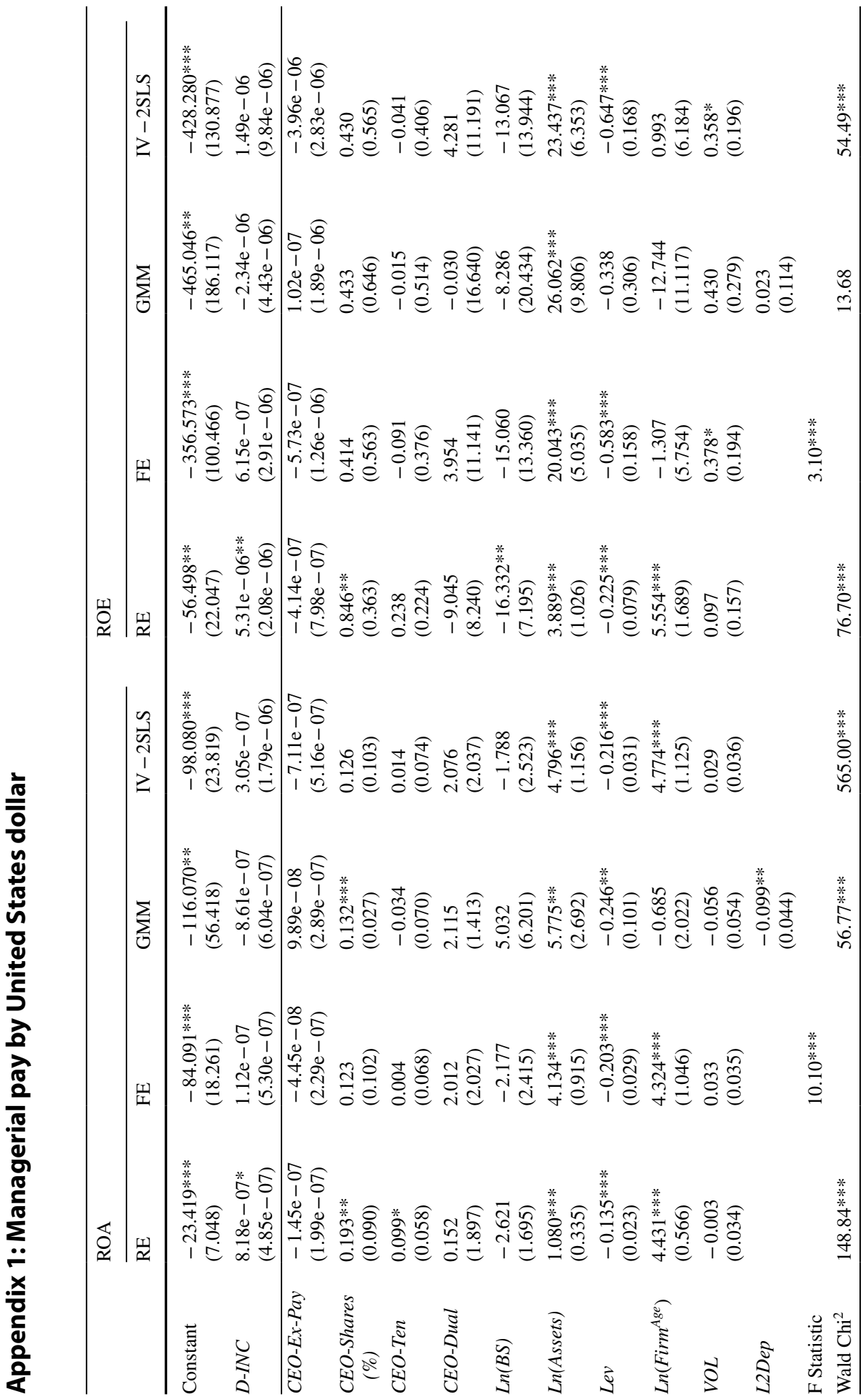




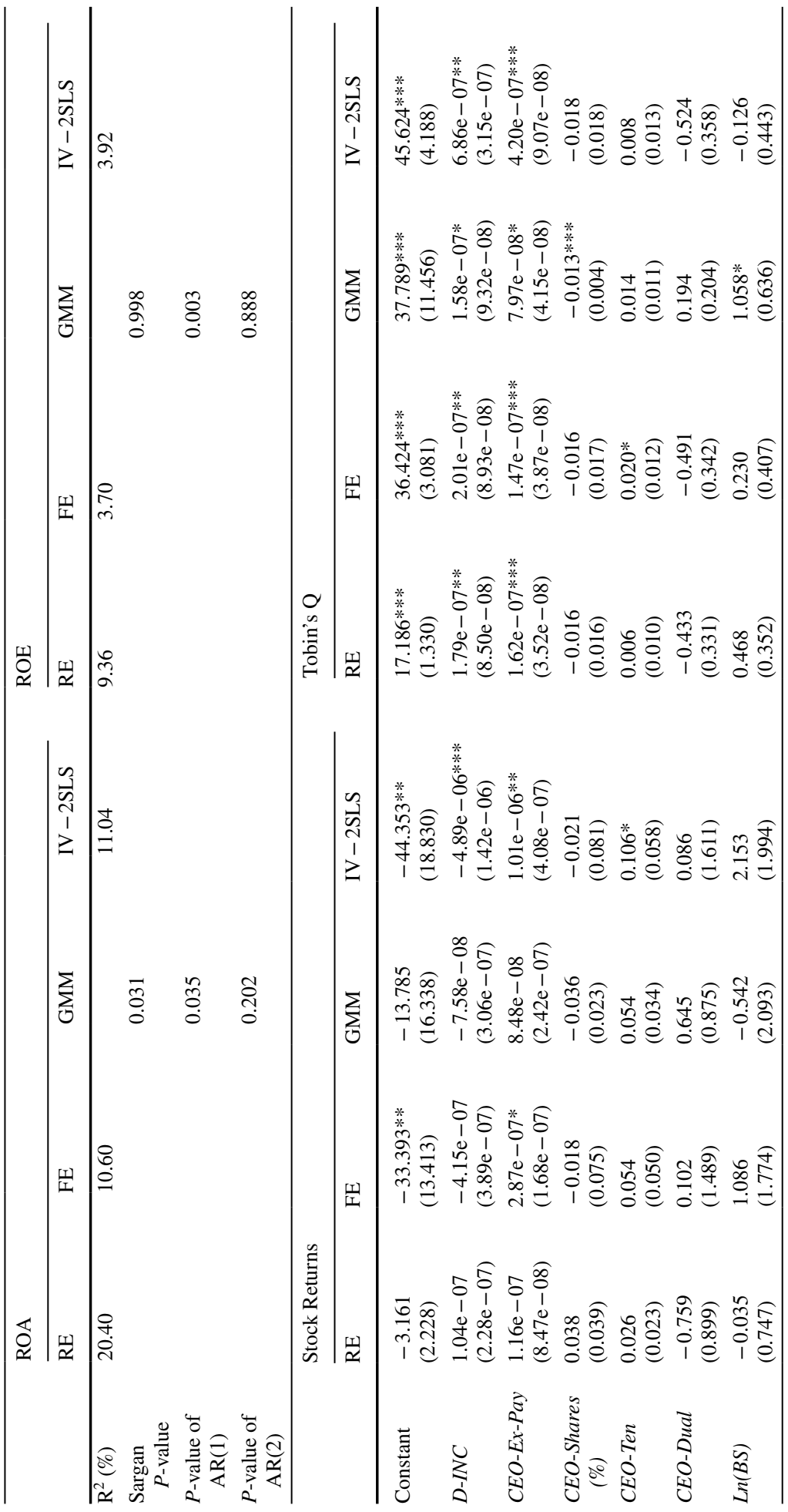




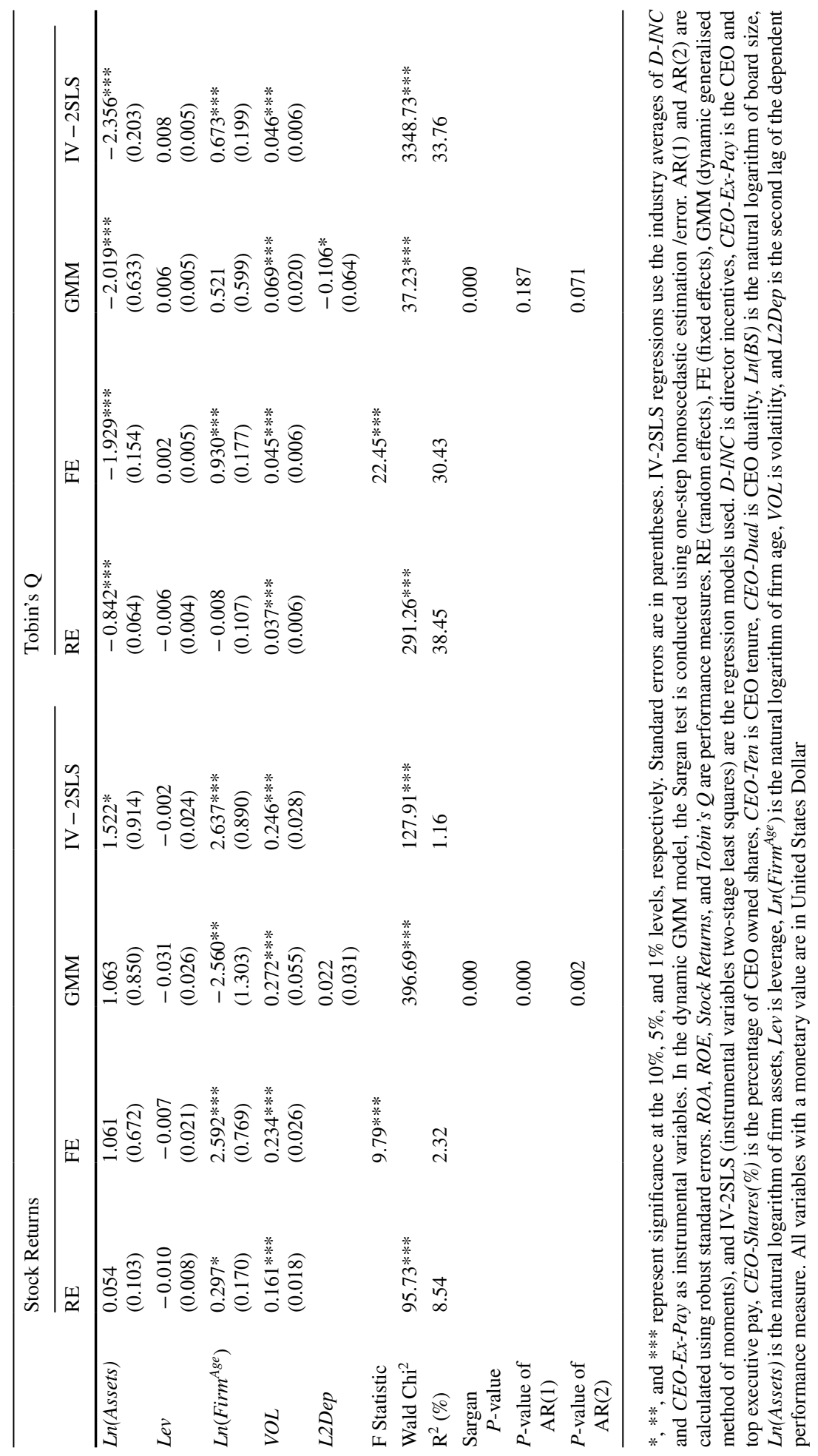




\section{Appendix 2: Correlation matrix for endogenous variables for government firm, 2008-2014}

\begin{tabular}{llllll}
\hline & & 1 & 2 & 3 & 4 \\
\hline 1 & D-INC & 1 & & & \\
2 & CEO-Ex-Pay & $0.313^{* * *}$ & 1 & & \\
& & $(0.000)$ & & & \\
3 & Average D-INC & $0.472^{* * *}$ & $0.436^{* * *}$ & 1 & \\
& & $(0.000)$ & $(0.000)$ & & \\
4 & Average CEO-Ex-Pay & $0.315^{* * *}$ & $0.697^{* * *}$ & $0.699^{* * * *}$ & 1 \\
& & $(0.000)$ & $(0.000)$ & $(0.000)$ & \\
\hline
\end{tabular}

*** represents significance at the $1 \%$ level. $P$-values are in parentheses. The correlation matrix for the endogenous variables and the average of the industry instrument variables discussed in Sect. 4 . Note that the industry average variable value is correlated with the endogenous director incentives and CEO and top executive pay on governments firms with correlations of 0.472 and 0.697 , respectively, as expected. Furthermore, industry average compensation is not expected to have a direct effect on individual governments firm performance. The industry averages for director incentives and for CEO and top executive pay are used as instrumental variables

Acknowledgements I thank the editor, Professor Cheng-Few Lee, and the reviewers for the helpful comments and suggestions that significantly enhanced this work. I also express my gratitude to the Saudi Arabia Capital Market Authority, Tadawul, and Mubasher for providing the data. The usual disclaimer applies.

\section{Declarations}

Conflicts of interest There are no conflicts of interest to declare.

Open Access This article is licensed under a Creative Commons Attribution 4.0 International License, which permits use, sharing, adaptation, distribution and reproduction in any medium or format, as long as you give appropriate credit to the original author(s) and the source, provide a link to the Creative Commons licence, and indicate if changes were made. The images or other third party material in this article are included in the article's Creative Commons licence, unless indicated otherwise in a credit line to the material. If material is not included in the article's Creative Commons licence and your intended use is not permitted by statutory regulation or exceeds the permitted use, you will need to obtain permission directly from the copyright holder. To view a copy of this licence, visit http://creativecommons.org/licenses/by/4.0/.

\section{References}

Adams M, Lin C, Zou H (2011) Chief executive officer incentives, monitoring, and corporate risk management: Evidence from insurance use. J Risk Insur 78(3):551-582. https://doi.org/10.1111/j.1539-6975. 2011.01409.x

Adams RB, Ferreira D (2007) A theory of friendly boards. J Financ 62(1):217-250. https://doi.org/10. 1111/j.1540-6261.2007.01206.x

Adams RB, Hermalin BE, Weisbach S (2010) The role of boards of directors in corporate governance: A conceptual framework and survey. J Econ Lit 48(1):58-107. https://doi.org/10.1257/jel.48.1.58

Adithipyangkul P, Leung TY (2018) Incentive pay for non-executive directors: The direct and interaction effects on firm performance. Asia Pac J Manag 35:943-964. https://doi.org/10.1007/ s10490-017-9534-z

Aggarwal R, Erel I, Stulz R, Williamson R (2009) Differences in governance practices between US and foreign firms: Measurement, causes, and consequences. Rev Financ Stud 22(8):3131-3169. https://doi. org/10.1093/rfs/hhn107 
Al Farooque O, Buachoom W, Hoang N (2019) Interactive effects of executive compensation, firm performance and corporate governance: evidence from an Asian market. Asia Pac J Manag 36:1111-1164. https://doi.org/10.1007/s10490-018-09640-2

Al-Faryan MAS, Dockery E (2017) Ownership structure and corporate governance: What does the data reveal about Saudi listed firms? Corp Ownersh Control 14(4-2):413-424. https://doi.org/10.22495/ cocv14i4c2art7

Alhassan AF, Bajaher MS, Alshehri A (2015) Corporate governance, firm attributes and financial performance of Saudi listed banks. World Rev Bus Res 5(3):282-295

Alhussayen H, Shabou R (2016) Intensive board monitoring and firm value: An empirical analysis in the context of Saudi Arabia. Int J Financ Res 7(5):146-164. https://doi.org/10.5430/ijfr.v7n5p146

Al-Matari YA, Al-Swidi AK, Bt Fadzil FH, Al-Matari EM (2012) Board of directors, audit committee characteristics and the performance of Saudi Arabia listed companies. Int Rev Manag Market 2(4):241251. https://www.econjournals.com/index.php/irmm/article/view/303. Accessed 1 November 2016

Almoneef A, Samontaray DP (2019) Corporate governance and firm performance in the Saudi banking industry. Banks and Bank Syst 14(1):147-158. https://doi.org/10.21511/bbs.14(1).2019.13

Al-Sager R, Samontaray DP (2018) Gender wise Saudi investors' awareness of corporate governance mechanism and its importance in their investment decision making - An empirical study. Int Bus Res 11(3):118-132. https://doi.org/10.5539/ibr.v11n3p118

Al-Sahafi A, Rodrigs M, Barnes L (2015) Does corporate governance affect financial performance in the banking sector? Evidence from Saudi Arabia. Int J Econ Commer Manag 3(3):1-26. http://ijecm.co. uk/wp-content/uploads/2015/03/333.pdf

Alshetwi M (2017) The association between board size, independence and firm performance: Evidence from Saudi Arabia. Glob J Manag Bus Res 17(1):17-28. https://journalofbusiness.org/index.php/ GJMBR/article/view/2204

Altuwaijri B, Kalyanaraman L (2016) Is 'excess' board independence good for firm performance? An empirical investigation of non-financial listed firms in Saudi Arabia. Int J Financ Res 7(2):84-92. https://doi.org/10.5430/ijfr.v7n2p84

Arellano M, Bond S (1988) Dynamic panel data estimation using DPD: A guide for users. Working Paper 88/15, Institute for Fiscal Studies, London

Arellano M, Bond S (1991) Some tests of specification for panel data: Monte Carlo evidence and an application to employment equations. Rev Econ Stud 58(2):277-297. https://doi.org/10.2307/2297968

Asch SE (1951) Effects of group pressure on the modification and distortion of judgments. In: Guetzknow $\mathrm{H}$ (ed) Groups, leadership and men. Carnegie Press, Pittsburgh, pp 177-190

Bahrawe SH, Haron MH, Bin Hasan AN (2016) Corporate governance and auditor independence in Saudi Arabia: Literature review and proposed conceptual framework. Int Bus Res 9(11):1-15. https://doi. org/10.5539/ibr.v9n11p1

Balasubramanian N, Black BS, Khanna V (2010) The relationship between firm-level corporate governance and market value: a case study of India. Emerg Mark Rev 11(4):319-340. https://doi.org/10.1016/j. ememar.2010.05.001

Balestra P, Varadharajan-Krishnakumar J (1987) Full information estimations of a system of simultaneous equations with error component structure. Econ Theor 3(2):223-246. https://doi.org/10.1017/S0266 466600010318

Baysinger BD, Butler HN (1985) Corporate governance and the board of directors: Performance effects of changes in board composition. J Law Econ Organ 1(1):101-124. https://doi.org/10.1093/oxfordjour nals.jleo.a036883

Berle AA, Means GC (1932) The modern corporation and private property. Macmillan, New York

Bertrand M, Mullainathan S (2003) Enjoying the quiet life? Corporate governance and managerial preferences. J Polit Econ 111(5):1043-1075. https://doi.org/10.1086/376950

Bhagat S, Black BS (2002) The non-correlation between board independence and long-term firm performance. J Corp Law 27(2):231-273

Bin L, Chen J, Ngo AX (2020) Revisiting executive pay, firm performance, and corporate governance in China. Econ Manag Financ Mark 15(1):9-32. https://doi.org/10.22381/EMFM15120201

Black B, Jang H, Kim W (2006) Does corporate governance affect firms' market values? Evidence from Korea. J Law Econ Org 22(2):366-413. https://doi.org/10.1093/jleo/ewj018

Black BS, Khanna VS (2007) Can corporate governance reforms increase firms' market values? Event study evidence from India. J Empir Legal Stud 4(4):749-796. https://doi.org/10.1111/j.1740-1461.2007. 00106.x

Black B, Kim W (2012) The effect of board structure on firm value: A multiple identification strategies approach using Korean data. J Financ Econ 104(1):203-226. https://doi.org/10.1016/j.jfineco.2011. 08.001 
Boone AL, Field LC, Karpoff JM, Raheja CG (2007) The determinants of corporate board size and composition: an empirical analysis. J Financ Econ 85(1):66-101. https://doi.org/10.1016/j.jfineco.2006.05. 004

Brick IE, Palmon O, Wald JK (2006) CEO compensation, director compensation, and firm performance: evidence of cronyism? J Corp Financ 12(3):403-423. https://doi.org/10.1016/j.jcorpfin.2005.08.005

Brickley JA, Coles JL, Terry RL (1994) Outside directors and the adoption of poison pills. J Financ Econ 35(3):371-390. https://doi.org/10.1016/0304-405X(94)90038-8

Brickley JA, James CM (1987) The takeover market, corporate board composition, and ownership structure: the case of banking. J Law Econ 30(1):161-180. https://doi.org/10.1086/467134

Broome LL, Conley JM, Krawiec KD (2011) Does critical mass matter? Views from the boardroom. Seattle Univ Law Rev 34:1049-1080. https://scholarship.law.duke.edu/faculty_scholarship/2460

Bruno V, Claessens S (2010) Corporate governance and regulation: Can there be too much of a good thing? J Financ Intermed 19(4):461-482. https://doi.org/10.1016/j.jfi.2009.10.001

Buallay A, Hamdan A, Zureigat Q (2017) Corporate governance and firm performance: Evidence from Saudi Arabia. Australasian Account Bus Financ J 11(1):78-98. https://doi.org/10.14453/aabfj.v11i1.6

Capital Market Authority (CMA) (2017) Corporate governance regulations in the Kingdom of Saudi Arabia. https://cma.org.sa/en/RulesRegulations/Regulations/Documents/CGRegulations_en.pdf Accessed 20 January 2018

Capital Market Authority (CMA) (2019) Imposition of a fine on Saudi Real Estate Co., due to the violation of the Rules on the Offer of Securities and Continuing Obligations. https://cma.org.sa/en/Market/ News/pages/CMA_N_2578.aspx Accessed 18 July 2020

Chen JJ, Liu X, Li W (2010) The effect of insider control and global benchmarks on Chinese executive compensation. Corp Gov 18(2):107-123. https://doi.org/10.1111/j.1467-8683.2010.00788.x

Cheung Y, Jing L, Lu T, Rau PR, Stouraitis A (2009) Tunneling and propping up: An analysis of related party transactions by Chinese listed companies. Pac-Basin Financ J 17(3):372-393. https://doi.org/10. 1016/j.pacfin.2008.10.001

Choi JJ, Park SW, Yoo SS (2007) The value of outside directors: Evidence from corporate governance reform from Korea. J Financ Quant Anal 42(4):941-962. https://doi.org/10.1017/S00221090000034 58

Chow GC (2007) China's economic transformation, 2nd edn. Wiley-Blackwell, New York

Cicero D, Wintoki MB, Yang T (2013) How do public companies adjust their board structures? J CorpFinanc 23:108-127. https://doi.org/10.1016/j.jcorpfin.2013.08.001

Claessens S, Yurtoglu BB (2013) Corporate governance in emerging markets: A survey. Emerg Mark Rev 15:1-33. https://doi.org/10.1016/j.ememar.2012.03.002

Coles JL, Daniel ND, Naveen L (2008) Boards: Does one size fit all? J Financ Econ 87(2):329-356. https:// doi.org/10.1016/j.jfineco.2006.08.008

Conyon MJ, He L (2011) Executive compensation and corporate governance in China. J Corp Financ 17(4):1158-1175. https://doi.org/10.1016/j.jcorpfin.2011.04.006

Conyon MJ, Nicolitsas D (1998) Does the market for top executives work? CEO pay and turnover in small UK companies. Small Bus Econ 11(2):145-154. https://doi.org/10.1023/A:1007908520404

Dahya J, Dimitrov O, McConnell JJ (2008) Dominant shareholders, corporate boards, and corporate value: a cross-country analysis. J Financ Econ 87(1):73-100. https://doi.org/10.1016/j.jfineco.2006.10.005

Dahya J, McConnell JJ (2007) Board composition, corporate performance, and the Cadbury committee recommendation. J Financ Quant Anal 42(3):535-564. https://doi.org/10.1017/S0022109000004099

Demsetz H, Lehn K (1985) The structure of corporate ownership: causes and consequences. J Polit Econ 93(6):1155-1177. https://doi.org/10.1086/261354

Demsetz H, Villalonga B (2001) Ownership structure and corporate performance. J Corp Financ 7(3):209233. https://doi.org/10.1016/S0929-1199(01)00020-7

Denis DK, McConnell JJ (2003) International corporate governance. J Financ Quant Anal 38(1):1-36. https://doi.org/10.2307/4126762

Duchin R, Matsusaka JG, Ozbas O (2010) When are outside directors effective? J Financ Econ 96(2):195214. https://doi.org/10.1016/j.jfineco.2009.12.004

Durnev A, Kim EH (2005) To steal or not to steal: Firm attributes, legal environment, and valuation. J Financ 60(3):1461-1493. https://doi.org/10.1111/j.1540-6261.2005.00767.x

Fahlenbrach R (2009) Shareholder rights, boards, and executive compensation. Rev Financ 13(1):81-113. https://doi.org/10.1093/rof/rfn011

Fallatah YA (2015) CEO compensation, firm performance and corporate governance: An empirical investigation of Saudi Arabian companies. MAGNT Res Rep 3(6):43-71

Fama EF (1980) Agency problems and the theory of the firm. J Polit Econ 88(2):288-307. https://doi.org/ $10.1086 / 260866$ 
Fama EF, Jensen MC (1983) Separation of ownership and control. J Law Econ 26(2):301-325. https://doi. org/10.1086/467037

Ferreira MA, Matos P (2008) The colors of investors' money: the role of institutional investors around the world. J Financ Econ 88(3):499-533. https://doi.org/10.1016/j.jfineco.2007.07.003

Ghabayen MA (2012) Board characteristics and firm performance: case of Saudi Arabia. Int J Account Financ Rep 2(2):168-200. https://doi.org/10.5296/ijafr.v2i2.2145

Glen J, Lee K, Singh A (2001) Persistence of profitability and competition in emerging markets. Econ Lett 72(2):247-253. https://doi.org/10.1016/S0165-1765(01)00425-6

Griliches Z, Hausman JA (1986) Errors in variables in panel data. J Econometr 31(2):93-118. https://doi. org/10.1016/0304-4076(86)90058-8

Grossman SJ, Hart OD (1983) An analysis of the principal-agent problem. Econometrica 51(1):7-45. https://doi.org/10.2307/1912246

Gschwandtner A (2005) Profit persistence in the 'very' long run: Evidence from survivors and exiters. Appl Econ 37(7):793-806. https://doi.org/10.1080/0003684042000337406

Gu Z, Wang K, Xiao X (2010) Government control and executive compensation: evidence from China. Working Paper. http://assets.csom.umn.edu/assets/160979.pdf Accessed 18 July 2020

Guest PM (2009) The impact of board size on firm performance: Evidence from the UK. Eur J Financ 15(4):385-404. https://doi.org/10.1080/13518470802466121

Gujarati DN (2004) Basic econometrics, 4th edn. The McGraw-Hill Companies, New York

Habbash MS, Bajaher MS (2015) An empirical analysis of the impact of board structure on the performance of large Saudi firms. Arab J Admin Sci 22(1):91-105. https://doi.org/10.34120/0430-022-001-005

Hamdan A (2018) Board interlocking and firm performance: The role of foreign ownership in Saudi Arabia. Int J Manag Financ 14(3):266-281. https://doi.org/10.1108/IJMF-09-2017-0192

Hansen LP, Singleton KJ (1982) Generalized instrumental variables estimation of nonlinear rational expectations models. Econometrica 50(5):1269-1286. https://doi.org/10.2307/1911873

Harris M, Raviv A (1979) Optimal incentive contracts with imperfect information. J Econ Theor 20(2):231259. https://doi.org/10.1016/0022-0531(79)90073-5

Harris M, Raviv A (2008) A theory of board control and size. Rev Financ Stud 21(4):1797-1832. https:// doi.org/10.1093/rfs/hhl030

Hausman JA (1978) Specification tests in econometrics. Econometrica 46(6):1251-1271. https://doi.org/10. 2307/1913827

He P, Wang K, Xiao X (2016) Does government control always reduce firm value? Theory and evidence from China. The political economy of Chinese finance (International Finance Review, Vol. 17), Emerald Group Publishing Limited, pp 151-187. Doi: https://doi.org/10.1108/S1569-3767201600 00017012

Hermalin BE, Weisbach MS (1988) The determinants of board composition. RAND J Econ 19(4):589-606

Hermalin BE, Weisbach MS (1991) The effects of board composition and direct incentives on firm performance. Financ Manag 20(4):101-112

Hermalin BE, Weisbach MS (1998) Endogenously chosen boards of directors and their monitoring of the CEO. Am Econ Rev 88(1):96-118

Hermalin BE, Weisbach MS (2003) Board of directors as an endogenously determined institution: A survey of the economic literature. Fed Bank NY Econ Pol Rev 9(1):7-26

Hirshleifer D, Suh Y (1992) Risk, managerial effort, and project choice. J Financ Intermed 2(3):308-345. https://doi.org/10.1016/1042-9573(92)90004-W

Jensen MC (1993) The modern industrial revolution, exit, and the failure of internal control systems. J Financ 48(3):831-880. https://doi.org/10.1111/j.1540-6261.1993.tb04022.x

Jensen MC, Meckling W (1976) Theory of the firm: Managerial behavior, agency costs and ownership structure. J Financ Econ 3(4):305-360. https://doi.org/10.1016/0304-405X(76)90026-X

Jensen MC, Murphy KJ (1990a) CEO incentives - It's not how much you pay, but how. Harvard Bus Rev 68(3):138-149. https://doi.org/10.1111/j.1745-6622.1990.tb00207.x

Jensen MC, Murphy KJ (1990b) Performance pay and top-management incentives. J Polit Econ 98(2):224264. https://doi.org/10.1086/261677

Jiang W, Ke B, Ru H, Xu Y (2020) Government control, top management team's pay dispersion and firm performance. Working paper. Doi: https://doi.org/10.2139/ssrn.3221600 Accessed 17 July 2020

Klapper LF, Love I (2004) Corporate governance, investor protection, and performance in emerging markets. J Corp Financ 10(5):703-728. https://doi.org/10.1016/S0929-1199(03)00046-4

Lahlou I, Navatte P (2017) Director compensation incentives and acquisition performance. Int Rev Financ Anal 53:1-11. https://doi.org/10.1016/j.irfa.2017.07.005

Lanne M, Saikkonen P (2011) GMM estimation with Non-causal Instruments. Oxford B Econ Stat 76(2):279-286. https://doi.org/10.1111/j.1468-0084.2010.00631.x 
Larmou S, Vafeas N (2010) The relation between board size and firm performance in firms with a history of poor operating performance. J Manag Gov 14:61-85. https://doi.org/10.1007/s10997-009-9091-Z

Lehn KM, Patro S, Zhao M (2009) Determinants of the size and composition of US corporate boards: 19352000. Financ Manag 38(4):747-780. https://doi.org/10.1111/j.1755-053X.2009.01055.X

Li K, Lu L, Mittoo UR, Zhang Z (2015) Board independence, ownership concentration and corporate performance - Chinese evidence. Int Rev Financ Anal 41:162-175. https://doi.org/10.1016/j.irfa.2015. 05.024

Linck JS, Netter JM, Yang T (2008) The determinants of board structure. J Financ Econ 87(2):308-328. https://doi.org/10.1016/j.jfineco.2007.03.004

Lipton M, Lorsch J (1992) A modest proposal for improved corporate governance. Bus Lawyer 48(1):59-77

Liu Y, Miletkov MK, Wei Z, Yang T (2015) Board independence and firm performance in China. J Corp Financ 30:223-244. https://doi.org/10.1016/j.jcorpfin.2014.12.004

Lovell MC (1986) Tests of the rational expectations hypothesis. Am Econ Rev 76(1):110-124

MacAvoy PW, Cantor S, Dana J, Peck S (1983) ALI proposals for increased control of the corporation by the board of directors: An economic analysis. Statement of the Business Roundtable on the American Law Institute's Proposal. Principles of corporate governance and structure: Restatement and recommendations. Business RoundTable, New York

Mace ML (1971) Directors: Myth and reality. Harvard Business School Press, Boston

Mace ML (1986) Directors: Myth and reality, 2nd edn. Harvard Business School Press, Boston

Marai A, Elghariani O, Pavlović V (2016) Practice and effectiveness of internal corporate governance mechanisms in Saudi Arabia stock market: A review of empirical evidence. Megatrend Rev 14(1):63-82. https://doi.org/10.5937/MegRev1701063M

Maug E (1997) Boards of directors and capital structure: Alternative forms of corporate restructuring. J Corp Financ 3(2):113-139. https://doi.org/10.1016/S0929-1199(96)00010-7

McCahery JA, Sautner Z, Starks LT (2016) Behind the scenes: The corporate governance preferences of institutional investors. J Financ 71(6):2905-2932. https://doi.org/10.1111/jofi.12393

McConnell JJ, Servaes H (1990) Additional evidence on equity ownership and corporate value. J Financ Econ 27(2):595-612. https://doi.org/10.1016/0304-405X(90)90069-C

Mehran H (1995) Executive compensation structure, ownership, and firm performance. J Financ Econ 38(2):163-184. https://doi.org/10.1016/0304-405X(94)00809-F

Mishra S (2020) Do independent directors improve firm performance? Evidence from India. Glob Bus Rev. https://doi.org/10.1177/0972150920917310

Morck R, Shleifer A, Vishny RW (1988) Management ownership and market valuation: An empirical analysis. J Financ Econ 20:293-315. https://doi.org/10.1016/0304-405X(88)90048-7

Moursli RM (2020) The effects of board independence on busy directors and firm value: Evidence from regulatory changes in Sweden. Corp Gov 28(1):23-46. https://doi.org/10.1111/corg.12301

Murphy KJ (1985) Corporate performance and managerial remuneration: An empirical analysis. J Account Econ 7(1-3):11-42. https://doi.org/10.1016/0165-4101(85)90026-6

Muth JF (1961) Rational expectations and the theory of price movements. Econometrica 29(3):315-335. https://doi.org/10.2307/1909635

Olaniyi CO, Olayeni OR (2020) A new perspective into the relationship between CEO pay and firm performance: Evidence from Nigeria's listed firms. J Soc Econ Dev. https://doi.org/10.1007/ s40847-020-00103-3

Patton A, Baker J (1987) Why do directors not rock the boat? Harvard Bus Rev 65(6):10-12

Paul JM (1992) On the efficiency of stock-based compensation. Rev Financ Stud 5(3):471-502. https://doi. org/10.1093/rfs/5.3.471

Puni A, Anlesinya A (2020) Corporate governance mechanisms and firm performance in a developing country. Int J Law Manag 62(2):147-169. https://doi.org/10.1108/IJLMA-03-2019-0076

Raheja CG (2005) Determinants of board size and composition: A theory of corporate boards. J Financ Quant Anal 40(2):283-306. https://doi.org/10.1017/S0022109000002313

Rashid MM (2020) Ownership structure and firm performance: The mediating role of board characteristics. Corp Gov 20(4):719-737. https://doi.org/10.1108/CG-02-2019-0056

Ricardo-Campbell R (1983) Comments on the structure of ownership and the theory of the firm. J Law Econ 26(2):391-393. https://doi.org/10.1086/467042

Roberts MR, Whited TM (2013) Endogeneity in empirical corporate finance. In: Constantinides GM, Harris M, Stulz RM (eds) Handbook of the economics of finance, vol 2. Elsevier, Amsterdam, pp 493-572. https://doi.org/10.1016/B978-0-44-453594-8.00007-0

Rosenstein S, Wyatt JG (1990) Outside directors, board independence, and shareholder wealth. J Financ Econ 26(2):175-192. https://doi.org/10.1016/0304-405X(90)90002-H 
Shan YG, McIver RP (2011) Corporate governance mechanisms and financial performance in China: Panel data evidence on listed non financial companies. Asia Pac Bus Rev 17(3):301-324. https://doi.org/10. $1080 / 13602380903522325$

Sloan RG (1993) Accounting earnings and top executive compensation. J Account Econ 16(1-3):55-100. https://doi.org/10.1016/0165-4101(93)90005-Z

Stulz RM (1988) Managerial control of voting rights: Financing policies and the market for corporate control. J Financ Econ 20:25-54. https://doi.org/10.1016/0304-405X(88)90039-6

Wang W (2014) Independent directors and corporate performance in China: A meta-empirical study. Working paper. Doi: https://doi.org/10.2139/ssrn.2417078 Accessed 20 January 2018

Wei W, Tang RW, Yang JY (2018) Independent directors in Asian firms: An integrative review and future directions. Asia Pac J Manag 35:671-696. https://doi.org/10.1007/s10490-017-9553-9

Weisbach MS (1988) Outside directors and CEO turnover. J Financ Econ 20:431-460. https://doi.org/10. 1016/0304-405X(88)90053-0

Weisbach MS (1993) Corporate governance and hostile takeovers. J Account Econ 16(1-3):199-208. https://doi.org/10.1016/0165-4101(93)90010-D

Wintoki MB, Linck JS, Netter JM (2012) Endogeneity and the dynamics of internal corporate governance. J Financ Econ 105(3):581-606. https://doi.org/10.1016/j.jfineco.2012.03.005

Yeh Y, Woidtke T (2005) Commitment or entrenchment? Controlling shareholders and board composition. J Bank Financ 29(7):1857-1885. https://doi.org/10.1016/j.jbankfin.2004.07.004

Yermack D (1996) Higher market valuation of companies with a small board of directors. J Financ Econ 40(2):185-211. https://doi.org/10.1016/0304-405X(95)00844-5

Zhao S (2020, January 8) China steps up Communist Party control in state-owned firms. Bloomberg News. https://www.bloomberg.com/news/articles/2020-01-08/china-steps-up-communist-party-control-instate-owned-firms Accessed 18 July 2020

Zhou X (2001) Understanding the determinants of managerial ownership and the link between ownership and performance: Comment. J Financ Econ 62(3):559-571. https://doi.org/10.1016/S0304-405X(01) 00085-X

Publisher's Note Springer Nature remains neutral with regard to jurisdictional claims in published maps and institutional affiliations.

\section{Authors and Affiliations}

\section{Mamdouh Abdulaziz Saleh Al-Faryan ${ }^{1,2,3,4,5,6,7}$ (D)}

1 Department of Economics and Finance, Faculty of Business and Law, University of Portsmouth, Richmond Building, Portland Street, Portsmouth PO1 3DE, UK

2 Consultant in Economics and Finance, Riyadh, Saudi Arabia

3 Member of The Saudi Economic Association, Riyadh, Saudi Arabia

4 Member of The Saudi Management Association, Riyadh, Saudi Arabia

5 Member of The Saudi Accounting Association, Riyadh, Saudi Arabia

6 Member of The Saudi Institute of Internal Auditors, Riyadh, Saudi Arabia

7 Member of The Saudi Association for Statistical Sciences, Asir - Abha, Saudi Arabia 